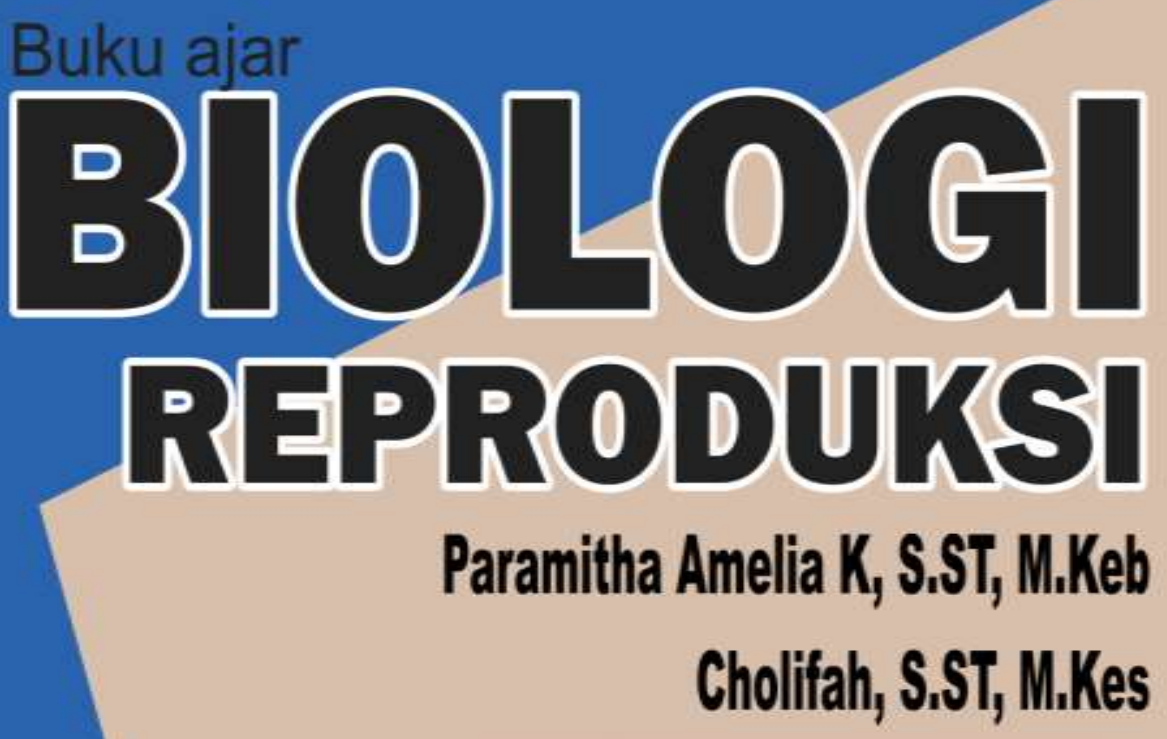




\section{BUKU AJAR \\ BIOLOGI REPRODUKSI}

\section{Penulis}

Paramitha Amelia. K, S.ST., M.Keb.

Cholifah, S.ST., M.Kes.

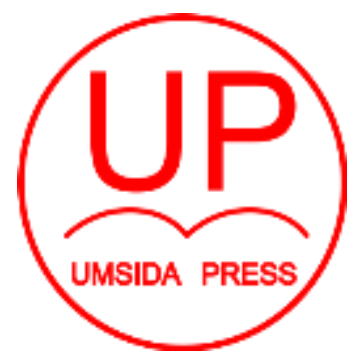

Diterbitkan oleh UMSIDA PRESS

Jl. Mojopahit 666 B Sidoarjo

ISBN: 978-602-5914-12-6

Copyright $@ 2018$.

Authors

All rights reserved 
BUKU AJAR

\section{BIOLOGI REPRODUKSI}

\section{Penulis :}

Paramitha Amelia. K, S.ST., M.Keb.

Cholifah, S.ST., M.Kes.

\section{ISBN :}

978-602-5914-12-6

\section{Editor :}

Septi Budi Sartika, M.Pd

M. Tanzil Multazam, S.H., M.Kn.

\section{Copy Editor :}

Fika Megawati, S.Pd., M.Pd.

Design Sampul dan Tata Letak :

Mochamad Nashrullah, S.Pd

\section{Penerbit :}

UMSIDA Press

\section{Redaksi :}

Universitas Muhammadiyah Sidoarjo

Jl. Mojopahit No 666B

Sidoarjo, Jawa TImur

\section{Cetakan pertama, Agustus 2018}

(C) Hak cipta dilindungi undang-undang

Dilarang memperbanyak karya tulis ini dengan suatu apapun tanpa ijin tertulis dari penerbit. 


\section{PRAKATA}

Puji syukur atas kehadirat Allah SWT yang telah melimpahkan rahmat, berkah, karunia, dan hidayah-Nya kepada penulis sehingga dengan izin-Nya penulis dapat menyelesaikan buku yang berjudul Biologi Reproduksi.

Penyusunan dan pembahasan buku ini mengacu pada kurikulum, GBPP dan silabus Mata Kuliah Biologi Reproduksi di Program Studi Kebidanan. Buku ini berisi materi-materi khusus tentang biologi yang berhubungan dengan sistem reproduksi manusia dan disusun bagi praktisi dan akademisi. Penulis berharap buku ini dapat menambah wacana buku ilmu pengetahuan pada bidang kesehatan, khususnya kebidanan dan membantu dalam pembelajaran yang menunjang terbentuknya tenaga bidan yang profesional.

Dalam kesempatan ini, penulis mengucapkan terima kasih kepada semua pihak yang telah banyak membantu, serta dukungan luar biasa yang diberikan kepada penulis sehingga buku ini dapat terselesaikan.

Penulis menyadari bahwa buku ini masih jauh dari sempurna, oleh karena itu penulis sangat mengharapkan saran dan kritik yang sifatnya membangun dari pembaca dan semua pihak sehingga buku ini kelak menjadi lebih sempurna dan bermanfaat.

Sidoarjo, Juli 2018 
COVER

PRAKATA

DAFTAR ISI.

BAB 1 STRUKTUR DAN FUNGSI SEL

1.1 SEL PROKARIOTIK DAN SEL EUKARIOTIK

1.2 SEL TUMBUHAN DAN SEL HEWAN/MANUSIA 2

1.3 STRUKTUR DAN FUNGSI SEL 3

1.4 ORGAN-ORGAN YANG BERPERAN DALAM 23 REPRODUKSI

\section{BAB 2 REGULASI HORMON}

2.1 REGULASI HORMON PADA ALAT REPRODUKSI PRIA 43

2.2 REGULASI HORMON PADA ALAT REPRODUKSI 44 WANITA

BAB 3 GAMETOGENESIS, FERTILISASI, DAN IMPLANTASI

3.1 GAMETOGENESIS

3.2 PROSES KEHAMILAN

3.3 TUMBUH KEMBANG FETUS

BAB 4 KODE GENETIK

4.1 PRINSIP HUKUM MENDEL

4.2 HEREDITAS MAMIRE

BAB 5 FISIOLOGI KEHAMILAN, PERSALINAN DAN NIFAS

5.1 FISIOLOGI KEHAMILAN

5.2 FISIOLOGI PERSALINAN

5.3 FISIOLOGI NIFAS 


\section{BAB 6 STRUKTUR PAYUDARA DAN FISIOLOGI LAKTASI}

6.1 STRUKTUR PAYUDARA

6.2 TAHAP PERKEMBANGAN PAYUDARA

6.3 HORMON-HORMON DALAM LAKTASI

6.4 FISIOLOGI LAKTASI DAN PROSES PEMBENTUKAN LACTOGEN

6.5 AIR SUSU IBU (ASI)

\section{BAB 7 PERKEMBANGAN DAN PERSIAPAN KEHIDUPAN} NEONATUS DARI INTRA KE EKSTRA-UTERUS

7.1 KEBUTUHAN NUTRISI PADA PERMULAAN KEHIDUPAN

7.2 PERKEMBANGAN SISTEM ORGAN FETUS

BAB 8 TRANSISI NEONATAL DARI INTRA KE EKSTRA

\section{UTERUS}

8.1 TRANSISI PADA SISTEM RESPIRASI

8.2 TRANSISI PADA SISTEM KARDIOVASKULER

8.3 TRANSISI PADA TERMOGULASI

8.4 TRANSISI PADA KEMAMPUAN MEMPEROLEH SUMBER GLUKOSA.

8.5 TRANSISI PADA DARAH

8.6 TRANSISI PADA SISTEM GASTROINTERSTINAL

8.7 TRANSISI PADA SISTEM IMUNITAS

DAFTAR PUSTAKA

BIODATA PENULIS

RINGKASAN 


\section{BAB I \\ STRUKTUR DAN FUNGSI SEL}

\subsection{SEL PROKARIOTIK DAN SEL EUKARIOTIK}

Golongan sel uekariotik meliputi sel-sel pada tubuh hewan/manusia dan tumbuhan, sedangkan pada mikroorganisme ada yang bersifat eukariotik-misalnya protozoa, protista, dan semua jamur dan yang bersifat prokariotik misalnya bakteri (Schizomycetes) dan blue green algae atau ganggang biru hijau (Cyanophyceae).

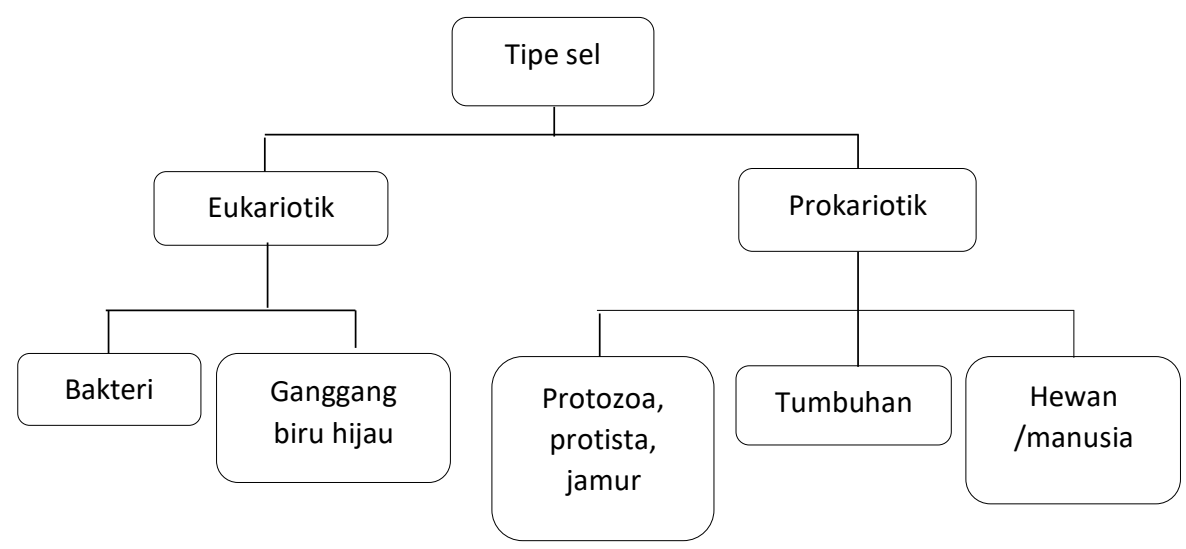

GAMBAR 1-1 Tipe sel dan contohnya

Sel bakteri dan ganggang biru hijau tidak memiliki kloroplas, mitokondria, dan nukleus (inti sel). Pada ganggang biru hijau dan bakteri, klorofil tersebar di dalam protoplasma dan nukleus tidak terlihat. Bahan nukleus tersebar di dalam protoplasma menyebabkan nukleus tidak dapat terlihat dan belum diselubungi membran. Nukleus seperti itu disebut prokarion dan sel yang memiliki nukleus prokarion dinamakan prokariotik. 
Sebaliknya, sel eukariotik memiliki nekleus yang sangat kompleks dan diselubungi oleh membran nukleus. Perbedaan di antara kedua golongan sel ini dapat dilihat pada Tabel 1-1.

TABEL 1-1 Perbedaan sel prokariotik dan sel eukariotik

\begin{tabular}{|l|c|c|}
\hline \multicolumn{1}{|c|}{ Struktur } & Prokariotik & Eukariotik \\
\hline Membran nukleus & - & + \\
\hline Membran plastida & - & + \\
\hline Nukleus & $+^{*}$ & + \\
\hline Plastida & - & + \\
\hline Mitokondria & - & + \\
\hline Badan Golgi & - & + \\
\hline DNA & + & + \\
\hline RNA & + & + \\
\hline Histon & - & + \\
\hline Pigmen & + & + \\
\hline
\end{tabular}

*Tidak terlihat

**Dari data tersebut sel bakteri dapat digunakan sebagai senjata biologis yang mematikan, karena meskipun termasuk sel prokariotik, bakteri mempunyai DNA maupun RNA.

\subsection{SEL TUMBUHAN DAN SEL HEWAN/MANUSIA}

Matthias Schleiden, seorang ahli anatomi tumbuhan, dan Theodor Schwann, ahli anatomi hewan, berpendapat bahwa setiap makhluk hidup tersusun oleh sel. Dengan kata lain, sel merupakan satuan (unit) struktural dari makhluk hidup.

Sediaan daun Elodea, Hydrilla, atau Vallisneria dan sediaan sel epitel pipi manusia dapat digunakan untuk membedakan struktur sel tumbuhan dan sel hewan. Pada sediaan sel daun Elodea dan sel epitel pipi manusia dengan mikroskop cahaya berdasarkan hasil pengamatan diperoleh data pada Tabel 1-2.

Dari tabel 1-2 dapat diketahui bahwa ciri khas sel tumbuhan adalah mempunyai dinding sel dan kloroplas. Sebaliknya sel 
manusia tidak memiliki dinding sel maupun kloroplas. Tetapi, baik sel tumbuhan maupun sel manusia memiliki membran sel, sitoplasma dan nukleus.

TABEL 1-2 Hasil pengamatan mikroskop cahaya pada sel tumbuhan dan manusia.

\begin{tabular}{|l|l|l|}
\hline Bagian sel & Sel daun Elodea & Sel epitel pipi manusia \\
\hline Sitoplasma & Ada & Ada \\
\hline Nukleus & Ada & Ada \\
\hline Kloroplas & Ada & Tidak ada \\
\hline Dinding sel & Ada & Tidak ada \\
\hline Membran sel & Ada & Ada \\
\hline
\end{tabular}

*Pada pembahasan kita tidak membedakan sel hewan dengan sel manusia, sebab dalam biologi, manusia adalah hewan vertebrata berderajat paling tinggi dilihat dari kerumitannya dalam berbagai aspek.

\subsection{STRUKTUR DAN FUNGSI SEL}

Secara struktural, sel merupakan suatu penyusun pada makhluk hidup uniseluler (bersel satu) atau makhluk hidup multiseluler (bersel banyak). Schleiden dan Schwann telah membuktikan melalui pengamatan mikroskopik bahwa makhluk hidup tersusun atas sel yang dirumuskan dalam teorinya yaitu sel merupakan satuan (unit) struktural dari makhluk hidup.

Max Schultze dan Thomas Huxley menyatakan dari teori sel merupakan satuan fungsional dari makhluk hidup, terlihat bahwa aktivitas yang berlangsung dalam tubuh makhluk hidup tercermin dari aktivitas dalam sel. Contoh dalam hal itu adalah sintesis, respirasi, dan transportasi. Komponen sel yang berupa nukleus, sitoplasma, membran sel dan organel-organel lain mendukung kelangsungan proses tersebut dan mempunyai fungsi khusus serta secara bersama-sama menyusun sistem yang kompak. 
Menurut Rudolf Virchow, sel berasal dari sel (omnis cellula e cellula) yang melahirkan teori sel yang menyatakan bahwa sel merupakan satuan pertumbuhan. Lahirlah teori sel yang menyebutkan bahwa sel merupakan satuan hereditas dari makhluk hidup dengan ditemukannya gen yang terdapat dalam kromosom yang ada di dalam nukleus. Sedangkan Walther Flemming dan Eduard Strasburger memunculkan teori baru yaitu sel merupakan satuan reproduksi dari makhluk hidup dengan mengamati pembelahan-pembelahan sel sel yang sehubungan dengan proses reproduksi sel.

Sel adalah jaringan penyusun bagian dalam tubuh manusia yang terdiri atas suatu membran limitas eksternal sitoplasma dari suatu inti. Berdasarkan penelitian biokimia diketahui bahwa reaksi kompleks terjadi didalam sel, tetapi tidak diketahui dengan pasti karena mikroskop hanya memperlihatkan bahwa sitoplasma mengandung sari sel dan struktur khusus yaitu organela.

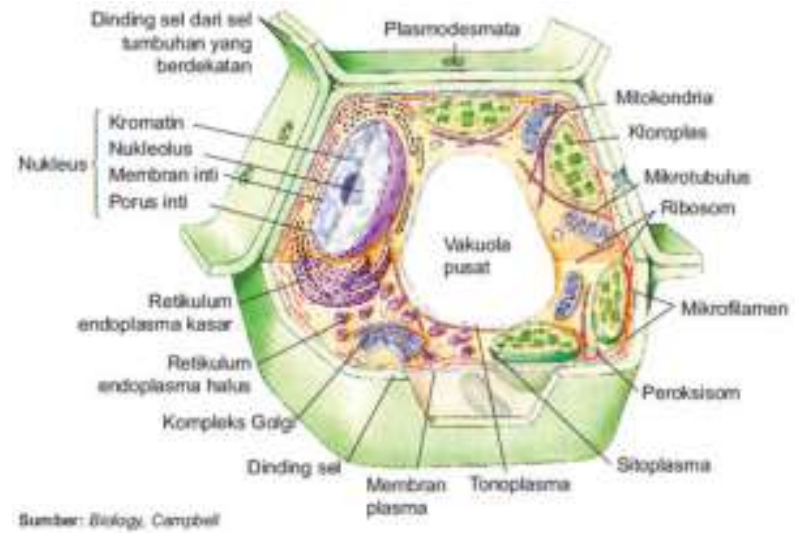

(a) 


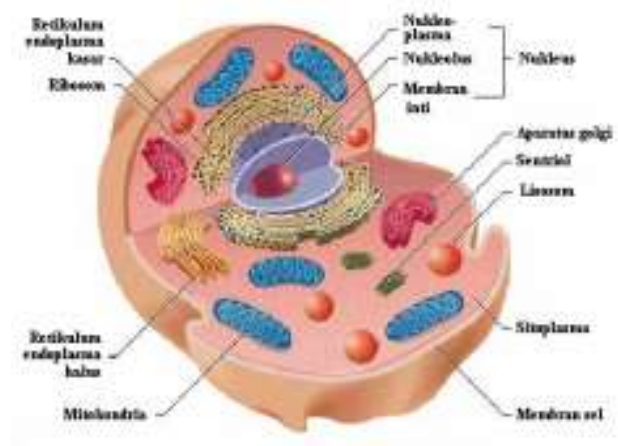

(b)

GAMBAR 1-2 (a) Sel Tumbuhan dan (b) sel hewan/manusia

\section{Struktur Sel}

Analisis kimiawi membran terdiri atas kompleks limpo protein. Mikroskop elektron resolusi memperlihatkan membran yang tersusun sebagai dua lamina padat elektron dengan suatu zona lusen elektron sentral. Perineum dan struktur tidak diketahui, tetapi dapat diperjelas dengan mikroskop elektron yang berfungsi melihat di mana membran terbentuk dari dua lapisan molekul lipid dengan ujung hidrofolikasi pada aspek luar dan rantai hidrofobik susunan pusat.

Sel terdiri atas bagian - bagian berikut ini.

1. Sitoplasma

2. Badan golgi

3. Sentriol

4. Lisosom

5. Inti

6. Nukleous

7. Membran inti

8. Retikulum endoplasmik halus

9. Retikulum endoplasmik kasar 
10. Membran sel

\section{Mitokondria}

12.Aparatus golgi

\section{Lisosom}

\section{Membran Sel (Membran Plasma, Selaput Plasma)}

Membran sel merupakan membran yang membatasi isi sel dari sekelilingnya. Membran ini tersusun dari membran dua-lapis yang terdiri fosfolipid dan protein (lipoprotein). Membran sel bersifat semipermeabel, artinya permeabel secara selektif, berfungsi mengatur pemasukan dan pengeluaran zat ke dalam dan ke luaar sel.

Berdasarkan analisis kimiawi, membran diketahui terdiri atas kompleks lipid-protein. Mikroskopis elektron resolusi tinggi memperlihatkan membran yang tersusun sebagai dua lamina padat elektron dengan suatu zona lusen elektron sentral. Perincian dari struktur tidak diketahui, tetapi model yang dapat menjelaskan sifat kimiawi dengan paling baik adalah gambaran yang diperoleh dari mikroskop elektron dan fungsi, yaitu model Singer dan Nicolson.

Membran dibentuk dua lapisan molekul lipid dengan ujung hidrofiliknya pada aspek luar dan rantai hidrofobik ke arah pusat. Komponen protein tersusun sebagai globulus yang dihubungkan dengan lipid melalui ikatan hidrofobik. Sejumlah protein melintasi seluruh lebar membran sehingga mempunyai gambaran pada kedua sisi, sedangkan yang lain hanya terlihat pada salah satu sisi atau sisi yang lainnya.

\section{Fungsi}

1. Transpor 
Membran sel merupakan sawar antara bagian dalam dan luar sel. Zat -zat harus melintasi membran ini untuk dapat masuk ke atau meninggalkan sel. Beberapa cara untuk melintasi membran ini adalah sebagai berikut.

a. Difusi

Cara ini merupakan proses pasif yang melibatkan ion-ion kecil dan air, serta bergantung pada gradien konsentrasi.

b. Pompa natrium

Untuk mempertahankan konsentrasi kalium yang tinggi di dalam sel dan konsentrasi natrium yang relatif rendah, natrium secara aktif dikeluarkan untuk ditukarkan dengan kalium melalui "pompa natrium" yang memerlukan energi.

c. Transfor aktif

Bahan baku untuk metabolisme seperti asam amino dan glukosa diangkut ke dalam sel. Proses ini melawan gradien konsentrasi sehingga memerlukan energi.

d. Transfer dalam jumlah besar

Sejumlah besar zat-zat dapat ditransfer ke dalam sel melalui invaginasi dari membran yang dilepaskan ke dalam sitoplasma untuk membentuk vakuola. Jika vakuola ini mengandung cairan, maka prosesnya diketahui sebagai pinositosis (sel yang minum) dan jika terdapat bahan padat dinamakan fagositosis (sel yang makan).

Demikian pula vakuola sekretorik dna ekskretorik yang dapat berfusi dengan membran sel dan mengeluarkan isinya. Proses ini disebut sebagai eksositosis.

2. Reseptor permukaan

Protein membran kemungkinan bertindak sebagai reseptor untuk zat-zat dalam transpor aktif, contohnya asam amino 
atau kelompok asam amino, dan dapat bertindak sebagai reseptor untuk hormon dan lain-lain. Selain itu, juga mempunyai peranan sebagai antigen permukaan sel.

\section{Sambungan}

Sel - sel tidak berfungsi secara tersendiri. Untuk membentuk organ-organ dan mempertahankan struktur diperlukan adanya komunikasi.

1. Kompleks sambungan

a. Zoluna Okludens

Jenis sambungan ini merupakan hubungan dimana lamina eksterna dari dua membran sel yang bertetangga tampak berdifusi.

b. Zoluna Adherens

Pada jenis ini terdapat suatu kesenjangan lusen elektron antara dua membran yang bertetangga. Diduga mengandung suatu zat yang bertindak sebagai perekat sel.

c. Makula Adherens atau Desmosom

Sambungan jenis ini khususnya ditemukan antara sel-sel yang mentransfer impuls listrik. Kedua membran dipisahkan oleh suatu kesenjangan lusen-elektron yang mengandung struktur-struktur yang melintasi dari sel satu ke sel yang lain.

2. Sambungan kesenjangan

Jenis sambungan keempat terutama ditemukan antara sel-sel yang mentransfer impuls listrik. Kedua membran dipisahkan oleh 
suatu kesenjangan lusen-elektron yang mengandung strukturstruktur yang melintasi dari satu sel ke sel yang lain.

\section{Membran inti}

Terdiri atas dua membran, masing-masing memiliki struktur ultra yang sama seperti membran sel, dipisahkan oleh suatu ruang-sisterna-perinuklear. Dalam interval-interval terdapat pori inti pada tepi, di mana membran eksterna dan interna bersatu. Diduga terdapat suatu membran tunggal yang melintasi masingmasing pori. Membran eksterna penuh dengan ribosom dan dilanjutkan dengan retikulum endoplasmik.

\section{Kromatin}

Kromatin pada manusia, terdiri dari 46 kromosom (22 pasang autosom dan sepasang kromosom seks). Kromosom hanya terlihat selama pembelahan sel. Pada tempat yang lain kromatin terdapat sebagai berikut.

a. Heterokromatin

Merupakan bahan kromosomal inaktif. Pulasan padat seperti yang ditemukan menempati sebagian besar inti limfosit.

b. Eurokromatin

Bahan kromosomal aktif, dengan pulasan lebih ringan seperti yang dapat ditemukan dalam inti sel plasma.

c. Kromatin seks

Juga dikenal sebagai "Badan Barr", terutama ditemukan dalam hapusan bukal. Berdekatan dengan membran inti dalam sel yang memiliki lebih dari satu kromosom $X$. Heterokromatin ini merupakan kromosom $X$ yang diinaktivasi. Wanita normal memiliki satu badan barr per sel, pria normal tidak memiliki kromatin seks.

\section{Nukleus (Inti Sel)}


Nukleus berbentuk bulat panjang dan dilindungi oleh membran nukleus (membran inti, selaput inti). Nukleus memiliki susunan molekul yang sama dengan membran sel yaitu berupa lipoprotein.

Di dalam nukleus terdapat :

\section{- Nukleolus (anak inti)}

Nukleolus (anak inti) berfungsi mensintesis berbagai macam molekul RNA yang digunakan dalam perakitan ribosom. Ribosom amat penting bagi sintesis protein dalam sel.

Kemungkinan terdapat satu atau beberapa struktur per inti. Mereka memiliki anyaman granular-nukleolonema, ruang penutup-pars amorfa. Diduga merupakan tempat produksi RNA dan lebih banyak di dalam sel yang secara metabolik aktif.

\section{- Nukleoplasma (cairan inti)}

Nukleoplasma (cairan inti) merupakan zat yang tersusun dari protein. Butiran kromatin terdapat pada nukleoplasma akan tampak jelas pada saat sel tidak membelah. Sedangkan pada saat membelah, butiran kromatin menebal menjadi struktur seperti benang yang disebut kromosom. Kromosom mengandung DNA yang berfungsi menyampaikan informasi genetik melalui sintesis protein.

\section{Sitoplasma}

Sitoplasma terdapat di dalam sel tetapi di luar nukleus dan organel-organel sel. Sitoplasma merupakan suatu koloid yaitu campuran heterogen yang stabil, dengan ukuran partikel terlarut 0,001-0,1 mikron. Sifat sitoplasma penyusun terbesarnya terdiri atas air yang di dalamnya terlarut banyak molekul kecil-kecil, ion, transparan, dan juga sejumlah besar protein. Koloid sitoplasma dapat mengalami perubahan dari fase sol ke gel atau sebaliknya. Jika konsentrasi air tinggi maka fase sol akan terjadi sedangkan sebaliknya jika konsentrasi air rendah maka fase gel terjadi. 
a. Sap sitoplasmik

Dengan adanya "pompa natrium", secara relatif terdapat konsentrasi yang tinggi dari kalium dan konsentrasi dari natrium yang relatif rendah dalam cairan intraselular dibandingkan cairan ekstraselular. Asam amino dan bahan kimiawi lain juga terdapat dalam konsentrasi yang lebih tinggi karena adanya transpor aktif.

b. DNA sitoplasmik

Adanya DNA dalam sitoplasma organisme bersel tunggal telah dikenal dengan baik, contohnya faktor transfer resistensi bakteri, yang kemungkinan bakteriofag, mengandung DNA. DNA sitoplasmik juga dipostulasi terdapat dalam sel-sel manusia.

\section{Organel-Organel}

\section{Mitokondria}

Mitokondria dinamakan "pusat tenaga" bagi sel karena mitokondria menyaring energi, sari makanan, zat gizi, dan oksigen. Mitokondria mempunyai dua lapisan membran (membran rangkap), yaitu membran luar dan membran dalam. Permukaan membran luar halus, sedangkan permukaan membran dalam berlekuk-lekuk. Perlekukan ini disebut krista. Pada bagian krista terdapat enzim untuk fosfoforilasi oksidatif dan sistem transpor elektron sedangkan enzim daur Krebs dan asam lemak terdapat dalam matriks mitokondria.

Organel ini menyediakan sebagian besar energi yang diperlukan di semua bagian sel untuk melakukan fungsi sel. Jumlah mitokondria dalam setiap sel berbeda-beda dari beberapa puluh sampai beribu-ribu, tergantung pada jumlah energi yang diperlukan oleh setiap sel. Selanjutnya, mitokondria dikonsentrasikan pada bagian sel ini yang bertanggung jawab atas sebagian besar metabolisme energinya. 


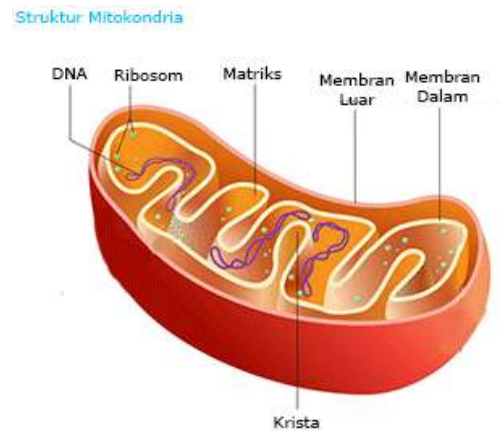

GAMBAR 1-3 Mitokondria

a. Ruang intermembran

Ruang intermembran (antarmembran) merupakan ruangan sempit diantara membran luar dan membran dalam. Membran luar dapat dilalui semua molekul kecil dan tidak dapat dilalui protein dan molekul besar.

b. Matriks mitokondria

Matriks mitokondria merupakan ruang yang diselubungi oleh membran dalam. Beberapa langkah metabolisme terjadi dalam matriks ini. Protein yang berperan dalam respirasi, termasuk enzim pembuat ATP, dibuat di membran dalam. Membran dalam juga memiliki permukaan yang luas sehingga dapat meningkatkan produktivitas respirasi selular. Bagian dalam matriks juga banyak mengandung protein dan DNA, ribosom, dan beberapa jenis RNA. Karena adanya DNA, RNA, dan ribosom, maka mitokondria dapat mensintesis protein sendiri.

DNA mitokondria berbeda dengan DNA di nukleus. DNA mitokondria terdapat dalam jumlah banyak ( lebih dari 1000 kopi) dalam tiap sel, sedangkan DNA nukleus hanya berjumlah dua kopi. 
Tidak seperti DNA nukleus yang berbentuk linear, DNA mitokondria berbentuk lingkaran. DNA nukleus merupakan hasil rekomendasi DNA kedua orangtua sementara DNA mitokondria relatif kecil jika dibandingkan dengan genom pada DNA nukleus, dan sebagian besar DNA mitokondria membawa gen yang berfungsi dalam proses respirasi selular.

\section{Retikulum Endoplasma (RE)}

Retikulum endoplasma (RE) merupakan perluasan membranmembran yang saling berhubungan yang membentuk saluran pipih seperti tabung di dalam sitoplasma. Dalam pengamatan mikroskop, Retikulum endoplasma tampak seperti saluran berkelok-kelok dan jala yang berongga-rongga. Saluran-saluran tersebut berfungsi untuk membantu gerakan substansi-substansi dari satu bagian sel ke bagian sel lainnya. Dalam sel terdapat dua tipe $R E$, yaitu retikulum endoplasma halus (REH) dan retikulum endoplasma kasar (REK).

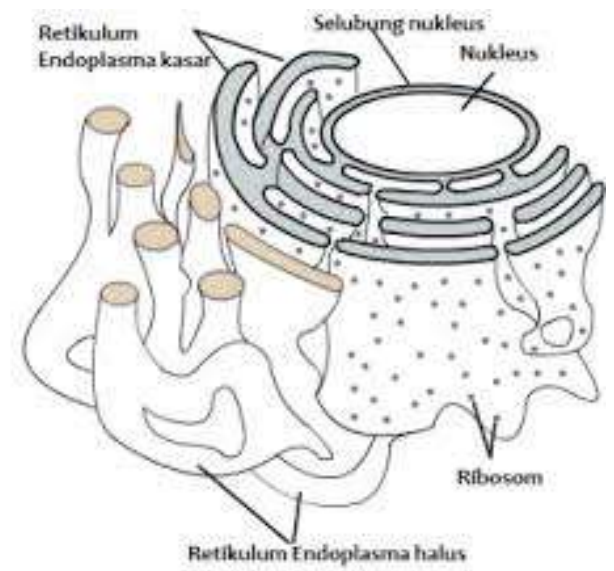

GAMBAR 1-4 Retikulum endoplasma (RE) 


\section{a. Retikulum endoplasmik halus (REH)}

Pada sitoplasma terdapat kompleks tuba dan sisterna yang saling berkomunikasi yang disebut retikulum endoplasmik, yang berhubungan dengan sisterna perinuklear.

Beberapa dari saluran ini memiliki ribosom yang melekat pada permukaan luar (retikulum endoplasmik kasar) dan beberapa saluran tidak memiliki (retikulum endoplasmik halus). REH merupakan tempat metabolisme steroid, sintesis glikogen dalam hepar, dan detoksifikasi obat. Peningkatan REH dapat ditimbulkan dalam sel-sel hepar melalui pemberian obat.

\section{b. Retikulum endoplasmik kasar (REK)}

Merupakan bentuk dari retikulum endoplasmik yang memiliki ribosom. Tipe RE ini disebut kasar karena permukaannya diselubungi oleh ribosom sehingga kelihatan seperti helaian panjang kertas pasir (ampelas). Ribosom merupakan tempat sintesis protein dan sintesis protein terjadi sepanjang ribosom serta REK terdapat banyak dalam sel-sel yang membentuk protein untuk "ekspor", contohnya sel plasma. Ribosom terbentuk dari RNA dan jika dinamakan REK, maka ribosom terdapat dalam jumlah yang besar. RNA dapat dilihat dengan melakukan pulasan sel dengan pironim.

Protein yang disintesis pada ribosom yang melekat pada retikulum endoplasmik biasanya ditujukan untuk luar sel. Sebagai contoh, sel-sel yang khusus untuk mensekresikan protein, misalnya sel pankreas yang menghasilkan hormon insulin, mengandung retikulum endoplasmik kasar yang besar.

Protein diangkut ke ruangan dalam RE setelah protein selesai dibuat oleh ribosom di permukaan RE. Dalam saluran ini, protein mungkin diubah oleh enzim-enzim yang berada di permukaan dalam membran RE, biasanya ditambah dengan molekul karbohidrat. Apabila protein telah mencapai ujung RE, protein 
tersebut disimpan dalam membran kecil yang mengandung kantong yang disebut vesikula. Vesikula dibentuk dari irisan RE halus yang berhubungan dengan RE kasar. Jadi fungsi RE adalah mendukung sintesis protein dan menyalurkan bahan genetik antara nukleus dengan sitoplasma.

\section{Aparatus golgi ( Badan golgi/Kompleks Golgi).}

Aparatus golgi terdapat hampir di semua sel dan memiliki bentuk bervariasi dari yang amorf sampai kantung-kantung pipih yang bertumpuk. Tumbuhan memiliki beberapa ratus aparatus golgi sedangkan setiap sel hewan/manusia memiliki 10 sampai 20 aparatus golgi. Aparatus golgi pada sel tumbuhan biasanya disebut diktosom. Aparatus golgi atau badan golgi dibangun oleh membran yang berbentuk tubulus dan juga vesikula. Dari tubulus dilepaskan kantong-kantong kecil yang berisi bahan-bahan yang diperlukan seperti enzim-enzim atau pembentuk dinding sel.

Berdekatan dengan inti, struktur ini terdiri atas tumpukan sisterna yang melengkung dan jika terbentuk dengan baik akan tampak sebagai zona jernih dalam sitoplasma, bila dilihat dengan mikroskop cahaya. Pada bagian ini, protein, enzim, dan lain-lain yang dihasilkan oleh sel dimodifikasi dan dikemas. Modifikasi kemungkinan merupakan kombinasi dengan karbohidrat membentuk glikoprotein, agregasi menjadi bentuk molekul kompleks lain, atau sulfasi. Vakuola yang mengandung produk akhir dilepaskan dari permukaan aparatus golgi. Vakuola-vakuola ini kemungkinan sekretorik atau mengandung peroksidaseperoksisomes atau enzim litik-lisosom.

Fungsi aparatus golgi antara lain adalah :

1. Membentuk kantong (vesikula) untuk sekresi, terjadi terutama pada sel-sel kelenjar. Vesikula tersebut berisi enzim atau bahan-bahan lain. 
2. Membentuk membran plasma. Kantong atau membran golgi sama seperti membran plasma. Kantong yang dilepaskan dapat menjadi bagian dari membran plasma.

3. Membentuk dinding sel tumbuhan.

4. Membentuk akrosom pada spermatozoa yang berisi enzim untuk memecah dinding sel telur dan pembentukan liposom

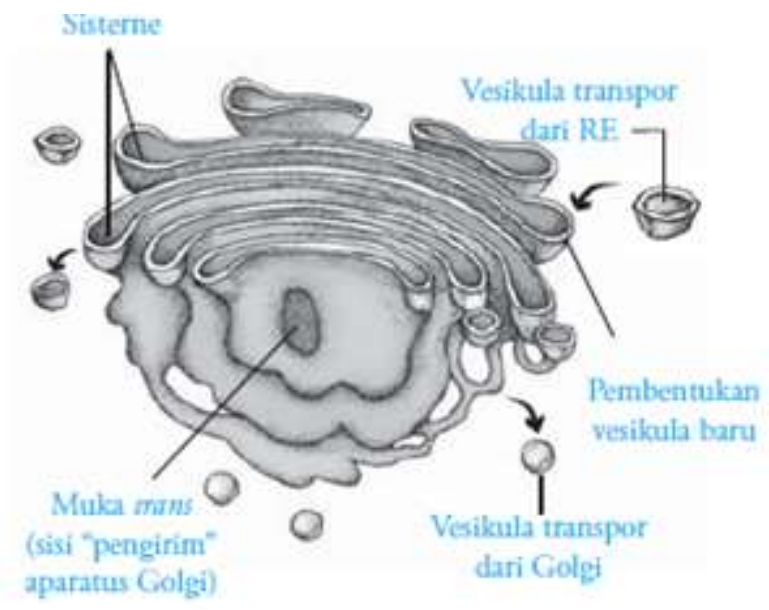

GAMBAR 1-5 Aparatus golgi (Badan Golgi)

\section{Ribosom}

Ribosom berupa organel kecil yang tersusun oleh RNA ribosom dan protein. Ribosom terdapat pada semua sel hidup dan mempunyai bentuk bundar. Ribosom terdapat bebas di sitoplasma dan melekat pada retikulum endoplasma kasar. Ribosom mengelompok membentuk poliribosom atau polisom.

\section{Lisosom}

Seperti disebut di atas, lisosom dilepaskan dari aparatus golgi sebagai vakuola yang mengandung enzim litik. Enzim-enzim ini berfungsi pada $\mathrm{pH}$ rendah dan memiliki dua sifat berikut. 
a. Digesti dari bahan yang difagositosis

Vakuola-vakuola fagostik yang kemungkinan mengandung benda asing (heterofagosom) atau komponen sel effete (autofagosom) berfusi dengan lisosom membentuk lisosom sekunder. Dalam vakuola ini, enzim lisosom bertindak terhadap bahan yang difagositosis dan mengubahnya menjadi zat-zat larut, yang kemungkinan dilepaskan ke dalam cairan sitoplasmik untuk ambil bagian dalam metabolisme sel.

Terkadang proses ini tidak lengkap dan masih tersisa bahan yang tidak tercerna. Partikel-partikel ini dikenal sebagai "bahan residual" dan di bawah mikroskop cahaya terlihat sebagai pigmen "wear an tear" (lusuh dan sobek).

b. Autolisis

Setelah kerusakan sel, jumlah autofagosom meningkat, bahan yang dirusak dicerna oleh fusi dengan lisosom. Jika terdapat cukup banyak cedera akan menyebabkan kematian sel. Membran lisosom mengalami ruptur dan terjadi autolisis total dari sel. Hal ini penting pada nekrosis dan autolisis postmortem.

Pada tahun 1955, para ahli biologi menemukan partikelpartikel yang sangat halus di dalam sitoplasma dengan menggunakan teknik ultrasentrifugasi. Oleh Christian de Duve, partikel halus yang ternyata berbentuk kantong-kantong kecil ini dinamakan lisosom.

Lisosom berbentuk agak bulat dan dibatasi membran tunggal. Lisosom dihasilkan oleh aparatus golgi yang penuh protein. Lisosom berisi enzim yang dapat memecahkan (mencerna) polisakarida, asam nukleat, polisakarida, lipid, fosfolipid dan protein. Karena itu, lisosom mempunyai peran dalam pencernaan intrasel, misalnya pada protozoa atau sel darah putih, juga dalam autofagi. Sebagai contohnya pada waktu 
kecebong berubah menjadi katak, ekornya diserap secara bertahap. Sel-sel ekor kecebong yang kaya akan lisosom akan mati dan hasil penghancurannya digunakan dalam pertumbuhan sel-sel baru yang berkembang. Lisosom terutama dapat ditemukan pada sel hewan/manusia.

\section{Sentriol-sentriol}

Berdekatan dengan inti, sebagian dikelilingi oleh aparatus golgi paling tidak terdapat dua sentriol. Sentriol terbentuk oleh sembilan triplets mikrotubulus yang berjarak sama, dikelilingi oleh dua mikrotubulus sentral. Pasangan sentriol ditempatkan tegak lurus satu sama lain. Fase pertama pembelahan sel didahului oleh reduplikasi dari sentriol yang kemudian bermigrasi ke kutub sel yang berlawanan membentuk spindel.

Flagela dan silia terdiri atas susunan mikrotubulus yang sama. Akan tetapi, pada beberapa kasus, mereka memiliki cincin eksterna dari sembilan mikrotubulus dobel daripada triplet.

\section{Badan Mikro (Peroksisom dan Glioksisom)}

Ukuran peroksisom hampir sama dengan lisosom. Peroksisom dibatasi oleh membran tunggal dan terdapat baik pada sel tumbuhan maupun sel hewan/manusia. Pada hewan/manusia, peroksisom banyak terdapat di sel hati dan ginjal sedangkan pada tumbuhan terdapat dalam berbagai tipe sel.

Peroksisom berisi penuh dengan enzim dan yang paling khas adalah katalase. Enzim ini mengkatalisis perombakan hidrogen peroksida $\left(\mathrm{H}_{2} \mathrm{O}_{2}\right)$, produk yang berpotensi membahayakan dari hasil metabolisme sel. Peroksisom juga berperan dalam perubahan lemak menjadi karbohidrat.

Glioksisom hanya terdapat pada sel tumbuhan, misalnya pada lapisan aleuron biji padi-padian. Aleuron merupakan bentuk dari protein atau kristal yang terdapat dalam vakuola. Glioksisom 
sering ditemukan di jaringan penyimpan lemak dari biji yang berkecambah. Glioksisom mengandung enzim pengubah lemak menjadi gula, proses perubahan ini menghasilkan energi yang diperlukan bagi perkecambahan.

\section{Plastida}

Plastida merupakan organel khas pada sel tumbuhan. Terdapat tiga macam plastida yaitu kromoplas, leukoplas, dan kloroplas.

1. Kromoplas, yaitu plastida berwarna yang mengandung pigmen selain klorofil.

2. Leukoplas, plastida yang berwarna putih berfungsi untuk menyimpan amilase (amiloplas), minyak (elaioplas), dan protein (laueorplas).

3. Kloroplas, yaitu plastida yang berwarna hijau karena mengandung klorofil. Kloroplas, seperti plastida lainnya, di sebelah luar dibatasi oleh dua laipsan membran (membran rangkap). Batas luar membran melingkupi matriks yang dinamakan stroma dan suatu sistem membran yang luas. Membran dalam terlipat berpasangan yang disebut lamela. Secara berkala lamela ini membesar sehingga terbentuk gelembung pipih terbungkus membran dan dinamakan tilakoid. Struktur ini tersusun dalam tumpukan, mirip koin. Tumpukan tilakoid dinamakan grana. Pada tilakoid terdapat unit fotosintesis yang berisi molekul pigmen seperti klorofil a, klorofil b, karoten dan xantofil. Analisis kimia dari kloroplas menunjukkan kloroplas terdiri dari fosfolipid, protein, pigmen hijau dan kuning, RNA dan DNA. 


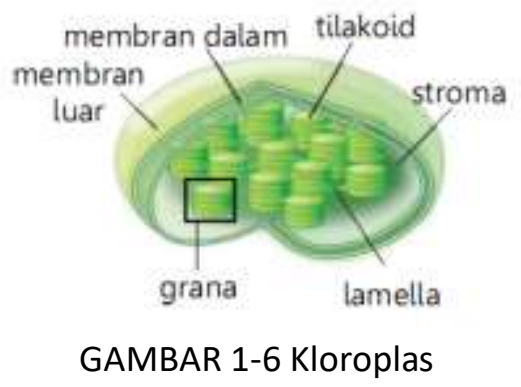

\section{Vakuola (rongga Sel)}

Vakuola merupakan organel sitoplasma yang berisi cairan, dibatasi oleh selaput yang disebut tonoplas. Pelipatan ke dalam dari sepotong membran sel membentuk vakuola.

Sel tumbuhan muda berisi banyak vakuola kecil, tetapi dengan matangnya sel, maka terbentuklah vakuola tengah yang besar. Vakuola berisi antara lain :

1. Asam organik

2. Asam amino

3. Glukosa

4. Gas

5. Garam-garam kristal

6. Minyak asiri (volatil), antosianin/zat warna

7. Alkaloid antara lain :

- Nikotin pada daun tembakau (Nicotiana tabacum)

- Kafein pada biji kopi (Coff'ea sp)

- Kinin pada kulit kina (Chinchona sp)

- Tein pada daun teh (Camellia sinensis)

- Teobromin pada buah cokelat / biji cokelat (Theobroma cacao)

- Solanin pada umbi kentang (Solanum tuberosum). 
Pada hewan bersel satu (protozoa), dikenal vakuola kontraktril atau vakuola berdenyut yang menetap, berfungsi sebagai osmoregulator yaitu menjaga nilai osmotik sel atau ekskresi. Vakuola nonkontraktil atau vakuola makanan mempunyai fungsi dalam pencernaan makanan dan mengedarkan hasil pencernaannya.

\section{Sitoskeleton.}

Sitoskeleton atau rangka sel tersusun atas tiga jenis serabut yang berbeda, yaitu mikrofilamen, mikrotubul, dan filamen intermediet.

a. Mikrofilamen atau filamen aktin.

Mikrofilamen merupakan rantai ganda protein yang saling bertaut dan tipis, terdiri dari protein yang disebut aktin. Mikrofilamen tidak terlihat bila terlihat bila diamati dengan mikroskop cahaya. Mikrofilamen berdiameter 5-6 nanometer $(\mathrm{nm})$, sehingga memerlukan mikroskop elektron untuk mengamatinya.

b. Mikrotubul.

Mikrotubul merupakan rantai protein yang berbentuk spiral dan spiral ini membentuk tabung berlubang. Mikrotubul tersusun atas bola-bola molekul yang lebih besar dari aktin, bola-bola ini disebut tubulin. Diameter mikrotubul lebih kurang $25 \mathrm{~nm}$. Mikrotubul juga merupakan serabut penyusun sitoskeleton terbesar. Mikrotubul dapat membentuk organel sitoplasma berupa sentriol, silia, dan flagela.

Sentriol berbentuk silindris dan tersusun dari mikrotubul yang tersusun sangat teratur. Sentriol akan membentuk benangbenang gelendong inti waktu sel membelah, silia dan flagel merupakan tonjolan yang dapat bergerak bebas, dapat 
dijulurkan dan juga tersusun dari mikrotubul. Mikrotubul mempunyai fungsi mengarahkan gerakan komponenkomponen sel, mempertahankan bentuk sel, serta membantu dalam pembelahan sel secara mitosis.

c. Filamen intermediat (serabut antara).

Filamen intermediat merupakan rantai molekul protein yang berbentuk untaian yang saling melilit. Filamen ini berdiameter 8-10 $\mathrm{nm}$. Disebut filamen intermediat atau serabut antara karena ukurannya berada di antara ukuran mikrotubul dan ukuran mikrofilamen. Serabut ini tersusun atas protein yang disebut fimentin, namun tidak semua sel tersusun atas fimentin. Sebagai contoh sel kulit, filamennya tersusun oleh protein keratin.

Fungsi sitoskeleton adalah sebagai berikut :

a. Memberikan kekuatan mekanik pada sel.

b. Menjadi kerangka sel.

c. Membantu gerakan substansi dari satu bagian sel ke bagian lainnya.

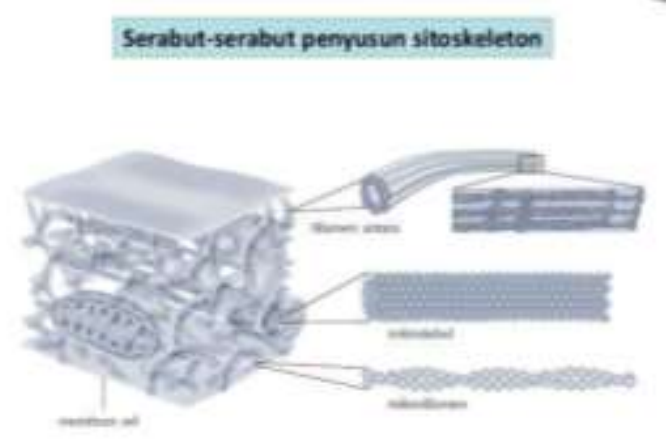

GAMBAR 1-7 Serabut-serabut penyusun sitoskeleton 


\subsection{ORGAN-ORGAN YANG BERPERAN DALAM REPRODUKSI}

\section{Organ Reproduksi Laki-laki}

Organ reproduksi laki-laki berasal dari jaringan embrional yang sama dengan organ reproduksi wanita, perkembangan atau pertumbuhan sel-sel mana yang akan terjadi ditentukan oleh hormon XX dan XY saat fertilisasi.

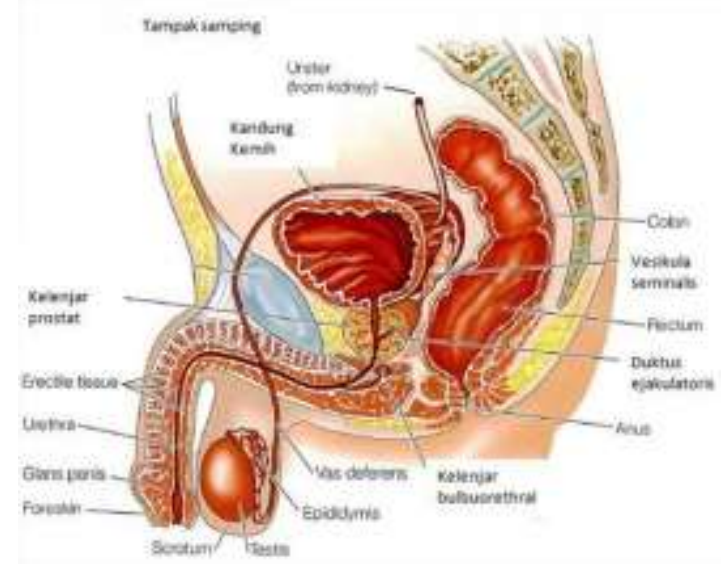

GAMBAR 1-8 Organ reproduksi laki-laki

\section{Organ Reproduksi Luar}

\section{Penis}

Terdiri atas jaringan-jaringan otot, jaringan spons yang lembut, pembuluh darah, dan jaringan saraf. Fungsinya yaitu untuk kopulasi (hubungan antara alat kelamin jantan dan betina). Untuk sebagian besar waktunya, penis tergantung lunglai di antara kedua paha, tergantung ke bawah di depan skrotum. Penis diselimuti oleh selaput tipis yang nantinya akan dioperasi pada saat dikhitan/sunat. Penis terdiri dari :

- Meatus uretra, lubang sebagai ttik keluarnya urine. 
- Glans penis, ujung distalnya berbentuk seperti struktur buah jati belanda.

- Prepusium, lipatan sirkuler kulit longgar yang merentang menutupi glans penis.

- Badan penis terdiri atas tiga rongga silindris (sinus) jaringan erektil.

a. Dua rongga yang berukuran lebih besar disebut korpus kavernosus, terletak bersebelahan.

b. Rongga yang ketiga disebut korpus spongiosum, mengelilingi uretra. Jika rongga tersebut terisi darah, maka penis menjadi lebih besar, kaku, dan tegak (mengalami ereksi).

\section{Buah zakar}

Terdiri atas kantung zakar yang di dalamnya terdapat sepasang testis dan bagian-bagian lainnya. Kulit luarnya disebut skrotum. Skrotum berfungsi melindungi testis, serta mengatur suhu yang sesuai untuk spermatozoa (sel sperma).

Testis terbentuk lonjong dengan ukuran sebesar buah zaitun dan terletak di dalam skrotum. Biasanya testis kiri agak lebih rendah dari testis kanan. Testis memiliki dua fungsi, yaitu menghasilkan sperma dan membuat testosteron (hormon seks pria yang utama).

\section{Skrotum (kantung pelir)}

Merupakan kantung longgar yang tersusun dari kulit, fasia, dan otot polos, kantung yang di dalamnya berisi testis. Skrotum berjumlah sepasang, yaitu skrotum kanan dan skrotum kiri. Antara skrotum kanan dan skrotum kiri dibatasi oleh sekat yang berupa jaringan ikat dan otot polos (otot dartos). Otot dartos berfungsi untuk menggerakkan skrotum sehingga dapat mengerut dan mengendur.

Dalam skrotum juga terdapat serat-serat otot yang berasal dari penerusan otot lurik dinding perut yang disebut otot 
kremaster. Otot ini bertindak sebagai pengatur suhu lingkungan testis agar kondisinya stabil. Proses pembentukan sperma (spermatogenensis) membutuhkan suhu yang stabil, yaitu beberapa derajat lebih rendah daripada suhu tubuh.

Skrotum merupakan kantung berkulit tipis yang mengelilingi dan melindungi testis. Skrotum juga bertindak sebagai sistem pengontrol suhu untuk testis agar sperma terbentuk secara normal, testis harus memiliki suhu yang sedikit lebih rendah dibandingkan dengan suhu tubuh. Otot kremaster pada dinding skrotum akan mengendur atau mengencang sehingga sehingga testis menggantung lebih jauh dari tubuh (dan suhunya menjadi lebih dingin) atau lebih dekat ke tubuh (dan suhunya menjadi lebih hangat).

\section{Organ Reproduksi Dalam}

Organ reproduksi dalam yaitu organ yang tidak tampak dari luar.

\section{Testis}

Testis sebenarnya adalah kelenjar - kelenjar kelamin, berjumlah sepasang dan akan menghasilkan sel-sel sperma, serta hormon testosteron. Organ lunak berbentuk oval dengan panjang 4-5 cm, lebar $2,5 \mathrm{~cm}$, dan tebal $3 \mathrm{~cm}$. Terdapat sepasang testis, yang masing-masing testis memiliki berat 1014 gram. Skrotum dapat menjaga suhu testis. Jika suhu terlalu panas, skrotum mengembang, jika suhu dingin skrotum mengerut sehingga testis lebih hangat.

Testis (gonad jantan) terletak di dalam kantung pelir (skrotum). Testis berjumlah sepasang (testes=jamak). Testis terdapat di bagian tubuh sebelah kiri dan kanan. Testis kiri dan kanan dibatasi oleh suatu sekat yang terdiri atas serat jaringan ikat dan otot polos. Fungsi testis secara umum merupakan alat 
untuk memproduksi sperma (spermatozoa) dan hormon kelamin jantan yang disebut testosteron.

Struktur mikroskopis testis adalah tunika albuginea (kapsul jaringan yang membungkus testis). Struktur makroskopis testis berupa jaringan glanduler atau kelenjar yang terbagi menjadi 200-300 lobi. Setiap lobus berisi tubulus seminiferus yang berkelok-kelok yang bermuara ke dalam vas deferens. Tubulus seminiferus mulai berkembang dari sel-sel sinsitium pada saat anak laki-laki berumur 7 tahun. Perkembangan tubulus yang cepat terjadi sampai umur 16 tahun, saat testis telah mencapai ukuran dewasa.

Kadang-kadang dapat dilihat spermatogonia sebelum anak lakilaki berumur 11 tahun yang dilihat pada pemeriksaan mikroskopik, tetapi produksi sperma setelah anak berusia 12 tahun sedangkan produksi sperma yang matur (matang) baru terjadi setelah anak berumur 16 tahun.

\section{Tubulus seminiferus}

Pada bagian dalam testis terdapat saluran-saluran halus yang disebut saluran penghasil sperma (tubulus seminiferus). Dinding dalam saluran terdiri atas jaringan epitel dan jaringan ikat. Pada jaringan epilium terdapat :

\begin{tabular}{|l|l|}
\hline \multicolumn{1}{|c|}{$\begin{array}{c}\text { Sel di dinding tubulus } \\
\text { seminiferus }\end{array}$} & \multicolumn{1}{c|}{ Fungsi } \\
\hline Sel induk sperma & Calon sperma \\
\hline Sel sertoli & Memberi makan sperma \\
\hline Sel leydig & $\begin{array}{l}\text { Menghasilkan hormon } \\
\text { testosteron }\end{array}$ \\
\hline
\end{tabular}




\section{Saluran Reproduksi (Saluran Pengeluaran)}

Saluran reproduksi adalah tempat sperma keluar atau jalan berupa lubang kecil yang menghubungkan organ dalam. Saluran pengeluaran pada organ reproduksi dalam pria terdiri atas epididimis, vans deferens, saluran ejakulasi, dan uretra.

\section{Epididimis}

Berupa saluran panjang berkelok yang keluar dari testis dan berupa pipa halus. Epididimis berjumlah sepasang di sebelah kanan dan kiri. Epididimis berfungsi sebagai tempat penyimpanan sementara sperma sampai matang dan bergerak menuju vans deferens. Epididimis terletak di atas testis dan merupakan saluran sepanjang $6 \mathrm{~cm}$. Epididimis mengumpulkan sperma dari testis dan menyediakan ruang, serta lingkungan untuk proses pematangan sperma, dengan cara menyimpan sperma dan mempertahankannya sampai enam minggu. Selama enam minggu ini sperma menjadi motil, matur, sempurna, dan mampu melakukan fertilisasi.

\section{Vas deferens}

Berupa saluran panjang dan lurus mengangkut sperma ke vesika seminalis dan panjangnya $45 \mathrm{~cm}$. Vas deferens atau saluran sperma (duktus deferens) merupakan saluran lurus yang mengarah ke atas dan merupakan lanjutan dari epididimis. Vans deferens tidak menempel pada testis dan ujung salurannya terdapat di dalam kelenjar prostat. Vas deferens berfungsi sebagai saluran tempat jalannya sperma dari epididimis menuju kantung semen atau kantung mani (vesikula seminalis).

Vas deferens merupakan saluran yang membawa sperma dari epididimis. Saluran ini berjalan ke bagian belakang prostat lalu masuk ke dalam uretra dan membentuk duktus ejakulatorius. 
Struktur lainnya (misalnya pembuluh darah dan saraf) berjalan bersama-sama vas deferens dan membentuk korda spermatika. Vas deferens merupakan saluran yang dapat diikat dan dipotong pada saat vasektomi. Sperma masih diproduksi dan memasuki vas deferens, tetapi sperma tersebut tidak dapat diejakulasikan sehingga mengalami degenerasi.

\section{Saluran ejakulasi (Duktus ejakulatoris)}

Merupakan saluran yang pendek dan menghubungkan vesikula seminalis dengan uretra serta merupakan pertemuan (ampula) di bagian ujung duktus deferens dan duktus vesikula seminalis. Setiap duktus menembus kelenjar prostat untuk bergabung dengan uretra yang berasal dari vesika urinaria dan panjangnya $2,5 \mathrm{~cm}$. Saluran ini berfungsi untuk mengeluarkan sperma agar masuk ke dalam uretra. Ejakulasi terjadi pada saat mencapai klimaks, yaitu ketika gesekan pada glans penis dan rangsangan lainnya mengirimkan sinyal ke otak dan korda spinalis.

Saraf merangsang kontraksi otot di sepanjang saluran epididimis dan vans deferens, vesikula seminalis dan prostat. Kontraksi ini mendorong semen ke dalam uretra. Selanjutnya kontraksi otot di sekeliling uretra akan mendorong semen keluar dari penis. Leher kandung kemih juga berkontriksi agar semen tidak mengalir kembali ke dalam kandung kemih. Setelah terjadi ejakulasi (atau setelah rangsangan berhenti), arteri mengencang dan vena mengendur. Akibatnya aliran darah yang masuk ke arteri berkurang dan aliran darah yang keluar dari vena bertambah, sehingga penis menjadi lunak.

\section{Uretra}

Merupakan saluran panjang terusan dari saluran ejakulasi dan terdapat di penis. Merentang dari vesika urinaria sampai ujung penis. Uretra ini mempunyai bagian antara lain :

- Uretra prostatik, mulai dari bagian dasar vesika urinaria menembus prostat. 
- Uretra membranosa, panjangnya 1-2 cm, dikelilingi sfingter uretra eksterna.

- Uretra penis, dikelilingi oleh jaringan erektil dan berakhir pada ostium uretra eksterna (glans penis).

\section{Kelenjar kelamin Pria}

\section{Vesikula Seminalis dan duktus seminalis}

Merupakan kantong-kantong kecil yang berbentuk tidak teratur, panjangnya $5 \mathrm{~cm}$, dan terletak di antara vesika urinaria dan rektum. Vesika seminalis berjumlah sepasang, terletak di bawah dan atas kandung kemih. Kelenjar ini merupakan tempat untuk menampung sperma sehingga disebut kantung semen, mensekresi cairan kental berwarna kekuningan yang kaya akan nutrisi bagi sperma dan bersifat alkali serta membantu cairan semen. Cairan tersebut mengandung glukosa yang berfungsi memberi nutrisi pada sperma (cairan semen) dan berfungsi untuk menetralkan

suasana asam dalam saluran reproduksi wanita. Masing-masing vesikula bermuara pada duktus seminalis yang bergabung dengan vas deferens pada sisi yang sesuai untuk membentuk dektus ejakulatoris.

\section{Kelenjar Prostat}

Kelenjar prostat melingkari bagian atas uretra dan terletak di bagian bawah kandung kemih. Kelenjar prostat menghasilkan getah yang mengandung kolesterol, garam, dan fosfolipid yang berperan untuk kelangsungan hidup sperma, selain menghasilkan struktur berbentuk kerucut dengan panjang $4 \mathrm{~cm}$, lebar $3 \mathrm{~cm}$, tebal $2 \mathrm{~cm}$, dan berat kira-kira 8 gram. 
Sekret prostat diproduksi terus-menerus dan disekresi dalam urine, setiap harinya kira-kira $1 \mathrm{~mL}$, tetapi jumlahnya bergantung pada testosteron, karena hormon ini yang merangsang sekresi tersebut. Sekret prostat mempunyai $\mathrm{pH}$ 6,6 dan susunannya seperti plasma, tetapi mengandung bahan-bahan tambahan seperti kolesterol, asam sitrat, dan enzim hialuronidase. Sekret prostat ditambahkan ke dalam sperma dan cairan semen pada saat sperma dan cairan semen melewati uretra.

\section{Kelenjar Cowper (Kelenjar Bulbouretra/Glandula bulbouretralis)}

Merupakan kelenjar yang salurannya langsung menuju uretra. Berbentuk seperti kacang kapri, berwarna kuning, terletak di bawah prostat, saluran kelenjar ini mempunyai panjang kira-kira 3 $\mathrm{cm}$, dan bermuara ke dalam uretra sebelum mencapai bagian penis. Sekresi dari glandula bulbouretralis mengeluarkan sedikit cairan sebelum ejakulasi dengan tujuan untuk melumasi panis sehingga mempermudah masuk ke dalam vagina. Kelenjar Cowper menghasilkan getah yang bersifat alkali (basa). Bila sekret prostat sendiri mempunyai pH 6,6 maka pH cairan semen secara keseluruhan sama dengan darah yaitu 7,5.

Organ-organ yang tidak terkait langsung dengan sistem reproduksi, tetapi letaknya berdekatan dengan organ-organ reproduksi adalah sebagai berikut :

1. Tulang kemaluan terletak di depan kantung kemih.

2. Rambut kemaluan berfungsi untuk menyaring kotoran agar tidak langsung menempel pada kulit kemaluan.

3. Rektum adalah bagian akhir dari usus besar terletak di atas anus. Rektum adalah tempat yang dilalui oleh kotoran.

4. Anus adalah tempat mengeluarkan kotoran/feses. 


\section{Gangguan pada Organ Reproduksi}

Organ reproduksi ini juga adakalanya mengalami gangguan biologi-anatomis. Kelainan ini seharusnya diketahui sedini mungkin agar memungkinkan tindakan operasi atau korektif untuk meminimalisasi efek negatifnya.

Jenis gangguan biologis dan anatomis yang sering dijumpai adalah sebagai berikut :

1. Cryptorchidism : testis hanya satu atau tidak ada di dalam skrotumnya.

2. Hipospadia : lubang keluar sperma/urine pada laki-laki di sebelah bawah biasanya ketika buang air kecil alirannya "tidak deras".

3. Pseudohermaphrodite : bentuk alat kelamin ganda laki-laki dan peremuan tetapi tidak sempurna; vagina tidak sempurna (tidak memiliki lubang vagina misalnya) atau tidak memiliki vagina.

4. Micro penis : penis kecil/tidak berkembang.

\section{Organ Reproduksi Wanita}

Organ genital wanita dibagi menjadi dua bagian, yaitu genital interna dan genital eksterna. Arteri pudendi yang merupakan cabang arteria femoralis memberikan vaskularisasi ke genital eksterna. Sebagian drainasenya menuju ke limfonodi inguinalis dan sebagian ke limfonodi iliaka eksterna. Cabang nervus pudendus dan nervus perinealis memberikan invervasi ke vulva.

Alat reproduksi dalam wanita terdiri atas ovarium, saluran reproduksi, uterus dan vagina.

\section{Ovarium}

Ovarium terletak pada daerah pinggang sebelah kiri dan kanan. Di dalam ovarium terdapat kelenjar endokrin penghasil hormon dan sel tubuh sebagai penghasil ovum (sel telur).

\section{Saluran reproduksi}


Saluran reproduksi pada wanita adalah oviduk atau tuba fallopi. Oviduk merupakan tempat terjadinya fertilisasi. Fertilisasi akan menghasilkan zigot yang akan bergerak menuju uterus. Gerakan zigot menuju uterus dibantu oleh silia pada oviduk dan gerak otot dinding oviduk.

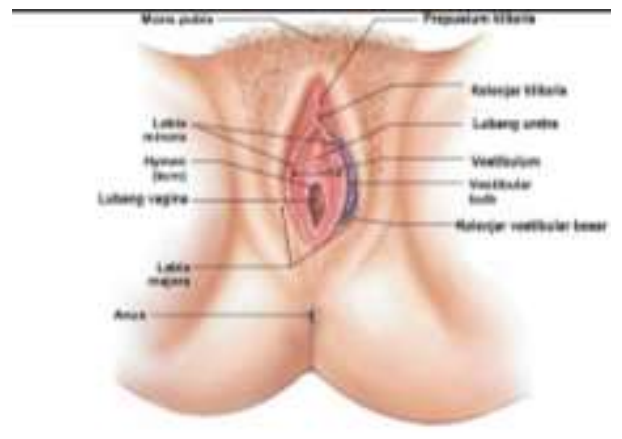

GAMBAR 1-9 Organ Reproduksi Eksterna pada Wanita

\section{Genetalia Eksterna}

\section{Vulva.}

Tampak dari luar (mulai dari mons pubis sampai tepi perineum), terdiri atas mons pubis, labia mayora, labia minora, klitoris, hymen, vestibulum, orifisium uretra eksternum, serta kelenjar-kelenjar pada dinding vagina.

\section{Mons pubis/mons veneris.}

Lapisan lemak di bagian anterior simfisis os pubis dan ditutupi oleh kulit. Pada masa pubertas daerah ini ditumbuhi rambut pubis.

3. Labia mayora. 
Dua lipatan bulat besar dari jaringan lemak yang tertutup oleh kulit yang bertemu di depan mons pubis dan merupakan lapisan lemak lanjutan mons pubis ke arah bawah dan belakang, banyak mengandung pleksus vena. Homolog embriologik dengan skrotum pada pria. Ligamentum rotundum uteri berakhir pada batas atas labia mayora. Pada bagian bawah perineum, labia mayora menyatu (pada komisura postererior).

Pada saat kedua labia mayora berjalan ke belakang ke arah anus, kedua labia menjadi lebih datar dan menuju ke depan korpus perinalis. Permukaan sebelah dalam labia mayora halus dan mengandung kelenjar keringat (glandula sudorifera) dan kelenjar minyak (glandula sebasea) sedangkan permukaan luarnya setelah pubertas akan tertutup oleh rambut.

\section{Labia minora.}

Merupakan dua lipatan berwarna merah muda yang lebih kecil dibanding labia mayora dan lipatan jaringan tipis di balik labia mayora, tidak mempunyai folikel rambut tetapi mengandung sejumlah glandula sudorifera dan glandula sebasea. Labia mayora terletak memanjang di bagian dalam labia mayora. Banyak terdapat pembuluh darah, otot polos, dan ujung serabut saraf.

Daerah yang ditutupi labia minora disebut vestibulum. Masingmasing labia minora terbagi menjadi dua lipatan di bagian anterior. Lipatan bagian atas mengelilingi klitoris dan berbentuk untuk membentuk prepusium. Dua lipatan bagian bawah melekat pada permukaan bawah klitoris disebut frenulum. Sedangkan fossa vestibula vaginae (fourchette) merupakan lipatan tipis yang terbentuk dan terletak dibawah posterior kedua labia minora, yang dapat mengalami robekan pada terjadinya robekan perineum saat melahirkan.

\section{Klitoris.}


Merupakan struktur terkecil yang sangat sensitif dan erektil, terletak di dalam lipatan prepusium dan frenulum. Terdiri atas kaput/glans klitoridis yang terletak di bagian superior dan korpus klitoridis yang tertanam di dalam dinding anterior vagina. Bagian ini homolog embriologik dengan penis pada pria. Terdapat juga reseptor androgen pada klitoris dan di klitoris tidak terdapat uretra. Banyak terdapat pembuluh darah dan ujung serabut saraf sehingga sangat sensitif.

\section{Vestibulum.}

Daerah dengan batas atas klitoris, batas bawah fourchet, dan batas lateral labia minora. Berasal dari sinus urogenital. Terdapat enam lubang/orifisium, yaitu orifisium uretra eksternum, introitus vagina, duktus glandula Bartholini kanankiri, dan duktus skene kanan-kiri. Antara fourchet dan vagina terdapat fossa navicularis. Terdapat 6 muara pada vestibulum.

\section{Introitus/orifisium vagina.}

Terletak di bagian bawah vestibulum. Pada gadis (virgo) tertutup lapisan tipis bermukosa yaitu selaput dara/hymen, utuh tanpa robekan. Hymen normal terdapat lubang kecil untuk aliran darah menstruasi, dapat berbentuk bulan sabit, bulat, oval, klibiformis, septum, atau fimbriae.

Akibat koitus atau trauma lain, hymen dapat robek dan bentuk lubang menjadi tidak beraturan dengan robekan (misalnya berbentuk fimbriae). Bentuk hymen postpartum disebut parous. Corrunculae myrtiformis adalah sisa-sisa selaput dara yang robek yang tampak pada wanita yang pernah melahirkan (para).

Hymen yang abnormal, misalnya primer tidak berlubang (hymen imperforata) menutup total lubang vagina, dapat menyebabkan darah menstruasi terkumpul di rongga genetalia interna.

\section{Vagina.}


Rongga muskulomembranosa berbentuk tabung mulai dari tepi serviks uteri di bagian kranial dorsal sampai ke vulva di bagian kaudal ventral, terletak antara kandung kemih dan rektum. Vagina memiliki dinding ventral dan dinding dorsal yang elastis. Dinding depan vagina $(9 \mathrm{~cm})$ lebih pendek dari dinding belakang $(11 \mathrm{~cm})$. Dilapisi epitel skuamosa berlapis, yang berubah mengikuti siklus haid.

Fungsi vagina yaitu untuk mengeluarkan ekskresi uterus pada haid, untuk jalan lahir dan untuk kopulasi (persetubuhan). Bagian atas vagina terbentuk dari duktus Mulleri, bawah dari sinus urogenitalis. Batas dalam secara klinis yaitu forniks anterior, posterior, dan lateralis di sekitar serviks uteri. Titik Grayenbergh (G-Spot) merupakan titik daerah sensorik di sekitar anterior dinding vagina, sangat sensitif terhadap stimulasi orgasmus vaginal.

Pada dinding vagina terdapat lipatan-lipatan yang berjalan sirkuler yang disebut dengan rugae, terutama pada bagian bawah vagina. Setelah melahirkan rugae akan menghilang. Walaupun terdapat lendir vagina, selaput ini tidak mempunyai kelenjar sama sekali sehingga tidak dapat menghasilkan lendir, mungkin lebih baik disebut kulit. Ke dalam puncak vagina menonjol ujung serviks yang disebut porsio. Oleh porsio, puncak vagina dibagi dalam empat kuadran yaitu forniks anterior, forniks posterior, serta forniks lateral kanan dan kiri. Sel-sel dari lapisan atas epitel vagina mengandung glikogen. Glikogen ini menghasilkan asam susu karena adanya basil. Basil deoderlin membuat vagina mempunyai sifat asam dengan $\mathrm{pH}$ 4,5 dan hal ini memberikan proteksi terhadap invasi kuman.

\section{Perineum.}

Daerah antara tepi bawah vulva dengan tepi depan anus. Batas otot-otot diafragma pelvis (muskulus levator ani, muskulus 
koksigis) dan diafragma urogenitalis (muskulus perinealis transversus profunda, muskulus konstriktor uretra). Perineal body adalah raphe median muskulus levator ani, antara anus dan vagina. Perineum meregang pada persalinan, kadang perlu dipotong (episiotomi) untuk memperbesar jalan lahir dan mencegah ruptur.

\section{Genetalia Interna.}

\section{Uterus.}

Suatu organ muskular berbentuk seperti buah pir, dilapisi peritoneum (serosa). Dalam keadaan tidak hamil, uterus terdapat dalam ruangan uterus pelvis minor di antara vesika urinaria dan rektum. Permukaannya belakangnya sebagian besar tertutup oleh peritoneum sedangkan permukaan depan hanya di bagian atasnya saja yang tertutupi. Bagian bawah dari permukaan depan melekat pada dinding belakang vesika urinaria. Selama kehamilan berfungsi sebagai tempat implantasi, retensi, dan nutrisi konseptus. Pada saat persalinan dengan adanya kontraksi dinding uterus dan pembukaan serviks uterus, isi konsepsi dikeluarkan.

Uterus merupakan alat yang berongga, berbentuk seperti bola lampu yang gepeng. Bentuk dan ukuran uterus sangat berbedabeda, tergantung pada usia dan pernah melahirkan anak atau belum. Panjang uterus pada anak-anak 2-3 cm, pada nullipara $6-8 \mathrm{~cm}$, pada multipara $8-9 \mathrm{~cm}$. Uterus terdiri atas korpus, fundus, kornu, isthmus, dan serviks uteri. Bagian korpus uteri di antara kedua pangkal tuba disebut fundus uteri (dasar rahim). Tepi kanan dan tepi kiri tidak tertutup oleh peritoneum karena berbatasan dengan parametrium kanan atau kiri.

Kavum uteri (rongga rahim) berbentuk segitiga dan lebar di daerah fundus serta sempit ke arah serviks. Sebelah atas 
rongga rahim berhubungan dengan saluran telur (tuba Fallopii) dan sebelah bawah dengan saluran leher rahim (kanalis servikalis). Hubungan antara kavum uteri dan kanalis servikalis disebut OUI (ostium uretra interna) sedangkan muara kanalis servikalis ke dalam vagina disebut OUE (ostium uteri eksterna). OUI terdapat dua buah yaitu OUI anatomikum yang merupakan batas antara kanalis servikalis dan kavum uteri, dan OUI histologikum pada kanalis servikalis tempat selaput lendir kavum uteri berubah menjadi selaput lendir serviks. Tempat ini letaknya sedikit di bawah OUI anatomikum.

\section{Serviks uteri.}

Bagian terbawah uterus, terdiri atas pars vaginalis (berbatasan/ menembus dinding dalam vagina) dan pars supravaginalis. Serviks terdiri dari tiga komponen utama yaitu otot polos, jalinan jaringan ikat (kolagen dan glikosamin), dan elastin. Bagian luar di dalam rongga vagina yaitu portio cervicis uteri (dinding) dan lubang ostium uteri eksternum (luar, arah vagina) dilapisi epitel skuamokolumnar mukosa serviks, dan ostium uteri internum (dalam, arah kavum).

Sebelum melahirkan (nullipara/primigravida) lubang ostium eksternum bulat kecil, tetapi setelah memiliki riwayat melahirkan (primipara/multigravida) akan berbentuk garis melintang. Posisi serviks mengarah ke kaudal-posterior, setinggi spina iskiadika. Kelenjar mukosa serviks menghasilkan lendir getah serviks yang mengandung glikoprotein kaya karbohidrat (musin) dan larutan berbagai garam, peptida, dan air. Ketebalan mukosa dan viskositas lendir serviks dipengaruhi siklus haid.

\section{Korpus uteri.}

Korpus uteri terdiri atas lapisan serosa/peritoneum yang melekat pada ligamentum latum uteri di intraabdomen (paling luar), lapisan muskular/miometrium berupa otot polos tiga 
lapis (dari luar ke dalam arah serabut otot longitudinal, anyaman, dan sirkular) (tengah), serta lapisan endometrium yang melapisi dinding kavum uteri (dalam), menebal dan runtuh sesuai siklus haid akibat pengaruh hormon-hormon ovarium.

Posisi korpus intraabdomen mendatar dengan fleksi ke anterior, fundus uteri berada di atas vesika urinaria. Proporsi ukuran korpus terhadap isthmus dan serviks uterus bervariasi selama pertumbuhan dna perkembangan wanita.

Panjang korpus uteri terhadap serviks uteri berbeda-beda. Pada anak-anak, panjang korpus uteri setengah dari panjangnya serviks uteri, pada gadis remaja sama panjangnya dengan serviks uteri, pada multipara korpus uteri dua kali panjang serviks uteri.

\section{Ligamentum penyangga uterus.}

Ligamentum latum uteri, ligamentum rotundum uteri, ligamentum cardinale, ligamentum ovarii, ligamentum sacrouterina propium, ligamentum infundibulopelvicum, ligamentum vesicouterina, dan ligamentum rectouterina.

\section{Vaskularisasi uterus.}

Terutama dari arteri uterina cabang arteri hipogastrika/illiaka interna, serta arteri ovarica cabang aorta abdominalis.

\section{Salping/tuba fallopi.}

Embriologik uterus dan tuba berasal dari duktus Mulleri. Terdapat pada tepi atas ligamentum latum, berjalan ke arah lateral mulai kornu uteri kanan-kiri. Sepasang tuba kiri-kanan, panjang 8-14 cm dan berdiameter 3-8 $\mathrm{mm}$. Berfungsi sebagai jalan transportasi ovum dari ovarium sampai kavum uteri.

Dinding tuba terdiri atas lapisan yaitu serosa, muskular (longitudinal dan sirkular), serta pars infundibulum dengan fimbria, dengan karakteristik silia dan ketebalan dinding yang berbeda-beda pada setiap bagiannya. 


\section{Pars isthmica (proksima/isthmus).}

Pars isthmica merupakan bagian dengan lumen tersempit, terdapat sfingter uterotuba pengendali transfer gamet. Pars ampularis (medial/ampula) merupakan tempat terjadinya fertilisasi. Bagian yang paling sering adalah daerah ampula/infundibulum, dan pada hamil ektopik (patologik) sering juga terjadi implantasi di dinding tuba bagian ini.

\section{Ovarium.}

Organ endokrin berbentuk oval, terletak di dalam rongga peritoneum, sepasang kiri dan kanan. Dilapisi mesovarium, sebagai jaringan ikat, serta jalan pembuluh darah dan saraf. Ovarium terdiri atas korteks dan medula. Ovarium berfungsi dalam pembentukan dan pematangan folikel menjadi ovum (dari sel epitel germinal primordial di lapisan terluar epitel ovarium di korteks), ovulasi (pengeluaran ovum), sintesis, dan sekresi hormon-hormon steroid (estrogen oleh teka interna folikel, progesteron oleh korpus luteum pascaovulasi). Berhubungan dengan pars infundibulum tuba fallopi melalui perlekatan fimbriae. Fimbriae "menangkap" ovum yang dilepaskan pada saat ovulasi.

Ovarium dihubungkan dengan uterus dan terfiksasi oleh ligamentum ovarii propium, dihubungkan dengan panggul oleh ligamentum infundibulopelvicum serta jaringan ikat mesovarium. Vaskularisasi dari cabang aorta abdominalis inferior terhadap arteri renalis. Terdapat pembuluh darah untuk ovarium, yaitu arteri ovarika dan vena ovarika.

Ovarium dibedakan menjadi :

- Permukaan medial yang menghadap ke arah kavum douglasi dan permukaan lateral.

- Ujung atas yang berdekatan dengan tuba dan ujung bawah yang lebih dekat dengan uterus. 
- Tepi yang menghadap ke muka (margo mesovarikus) melekat pada lembar belakang ligamentum latum dengan perantaraan mesovarium dan tepi yang menghadap ke belakang (margo fiber). Ovarium letaknya pada dinding lateral punggul dalam sebuah lekuk yang disebut fossa ovarika Waldeyeri. Ovarium terdiri dari bagian luar (korteks) dan bagian dalam (medula). Pada korteks terdapat folikelfolikel primordial. Pada medula terdapat pembuluh darah, saraf, dan pembuluh limfa.

\section{Parametrium.}

Merupakan jaringan ikat yang terdapat di antara kedua lembar ligamentum latum. Bagian atas ligamentum latum yang mengandung tuba disebut mesosalping dan bagian kaudalnya yang berhubungan dengan uterus disebut mesometrium. Pada sisi depan ligamentum latum berjalan ligamentum teres uteri, pada permukaan belakang ligamentum ovarii propium. Mesovarium merupakan lipat peritoneum untuk ovarium dan terdapat di antara mesosalping dan mesometrium. Pada parametrium ini berjalan arteri dan vena uterina. Parametrium sebelah bawah yang menyelubungi arteri dan vena uterina lebih padat daripada jaringan sekitarnya disebut ligamentum kardinal

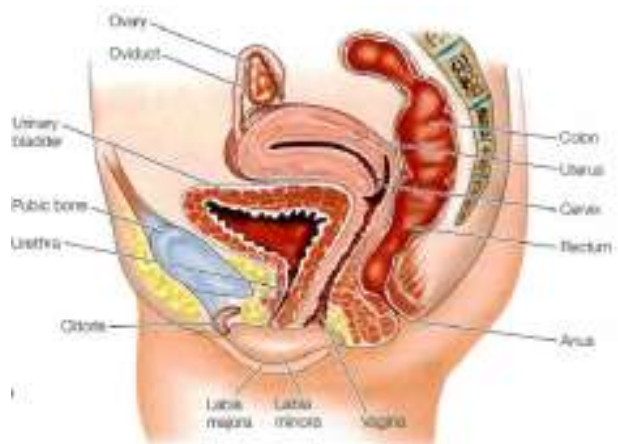

GAMBAR 1-10 Organ reproduksi interna pada wanita 


\section{BAB 2}

\section{REGULASI HORMONAL}

\subsection{REGULASI HORMONAL PADA ALAT REPRODUKSI PRIA.}

Hormon androgen merupakan hormon kelamin utama pada pria. Jenis hormon androgen yang terpenting adalah testosteron. Hormon androgen diproduksi oleh sel-sel interstisial dari testis yang bertanggung jawab terhadap perkembangan sifat-sifat kelamin primer dan sekunder pada pria. Perkembangan sistem reproduksi pria dan produksi spermatozoa berhubungan dengan sifat kelamin primer sedangkan sifat kelamin sekunder berkenaan dengan ciri kejantanan yang tidak berkaitan langsung dengan sistem reproduksi, seperti jakun, suara, janggut dan lain-lain. Androgen menentukan pula tingkah laku pria, tingkah laku seksual, dan libido seksualis.

Hipofisis memproduksi dua jenis hormon gonadotropin yakni LH dan FSH setelah distimulasi oleh hipotalamus dan memberikan efek berbeda terhadap testis. Hormon LH (luteinizing hormone) yang dihasilkan oleh lobus anterior hipofisis dan menstimulasi selsel interstisial dari testis untuk memproduksi androgen. Hormon FSH (follicle-stimulating hormone) juga dihasilkan oleh lobus anterior hipofisis dan menginduksi tubuli seminiferi untuk meningkatkan produksi spermatozoa. Berhubung hormon androgen juga diperlukan untuk produksi spermatozoa, maka hormon LH secara tidak langsung menstimulasi proses spermatogenesis.

Produksi hormon LH dan FSH dikontrol oleh jenis hormon yang dihasilkan oleh hipotalamus yakni hormon GnRH (gonadotropinreleasing hormone). Konsentrasi $\mathrm{LH}, \mathrm{FSH}$, dan $\mathrm{GnRH}$ diatur secara umpan balik oleh hormon androgen. Pada pria, umpan balik ini 
menjaga konsentrasi hormon-hormon agar tetap konstan. Pada kebanyakan hewan mamalia terjadi daur musiman produksi hormon yang berkaitan dengan musim berkelamin (estrus).

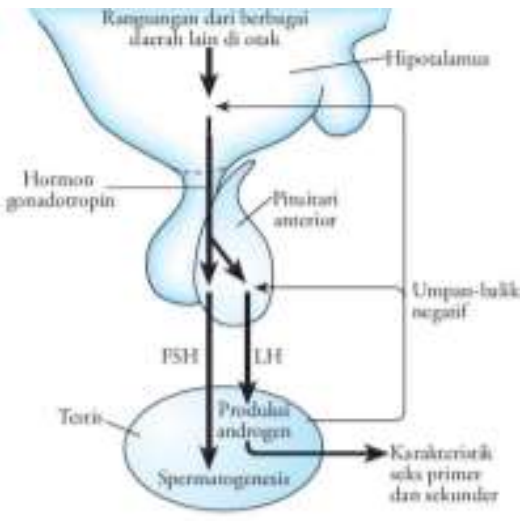

GAMBAR 2-1 Kontrol hormonal pada alat reproduksi pria

\subsection{REGULASI HORMONAL PADA ALAT REPRODUKSI WANITA.}

Dinding uterus terdiri atas tiga lapisan. Dari ruang uterus ke permukaan lapisan-lapisan tersebut adalah endometrium, miometrium, dan perimetrium. Endometrium mempunyai peran dalam daur menstruasi dan dibagi atas tiga lapisan yaitu stratum kompaktum, stratum spongiosum dan stratum basalis.

Pada stratum kompaktum (permukaan endometrium) dilapisi sel-sel epitel. Pembuluh darah arteri ada yang berjalan melilit (spiral) dan ada pula yang lurus vertikal di daerah stratum basalis.

Sekurang -kurangnya ada lima hormon utama yang berperan dalam regulasi (pengaturan) dan koordinasi daur ulang pembentukan folikel di ovarium dan daur menstruasi di uterus, yaitu : 
a. GnRH (gonadotropin-releasing hormone) yang dihasilkan oleh hipotalamus di otak.

b. FSH (follicle-stimulating hormone) yang dihasilkan oleh lobus anterior hipofisis.

c. LH (luteinizing hormone) yang dihasilkan oleh lobus anterior hipofisis.

d. Esterogen yang dihasilkan oleh teka folikuli interna dari folikel yang sedang berkembang menjadi folikel de Graaf.

e. Progesteron yang dihasilkan oleh korpus luteum.

\section{GONADOTROPHIN RELEASING HORMONE (GnRh)}

GnRH merupakan hormon yang diproduksi oleh hipotalamus di otak. GnRH akan merangsang pelepasan Follicle Stimulating Hormone (FSH) di hipofisis. Bila kadar esterogen tinggi, maka esterogen akan memberikan umpan balik ke hipotalamus sehingga kadar GnRH akan menjadi rendah, begitupun sebaliknya.

Hormon ini diproduksi di hipotalamus, kemudian dilepaskan, berfungsi menstimulasi hipofisis anterior untuk memproduksi dan melepaskan hormon-hormon gonadotropin (FSH/LH).

\section{FOLLICLE STIMULATING HORMONE (FSH).}

Hormon ini diproduksi pada sel-sel basal hipofisis anterior, sebagai respons terhadap $\mathrm{GnRH}$ yang berfungsi memicu pertumbuhan dan pematangan folikel dan sel-sel granulosa di ovarium wanita (pada pria memicu pematangan sperma di testis).

Pelepasannya periodik/pulsatif, waktu paruh eliminasinya pendek (sekitar 3 jam), sering tidak ditemukan dalam darah. Sekresinya dihambat oleh enzim inhibin dari sel-sel granulosa ovarium, melalui mekanisme umpan balik negatif.

\section{LUTEINING HORMONE (LH) / INTERSTITIAL CELL STIMULATING HORMONE (ICSH)}


Hormon ini diproduksi di sel-sel kromofob hipofisis anterior. Bersama FSH, LH berfungsi memicu perkembangan folikel (sel-sel teka dan sel -sel granulosa) dan juga mencetuskan terjadinya ovulasi di pertengahan siklus (LH-surge). Selama fase luteal siklus, LH meningkatkan dan mempertahankan fungsi korpus luteum pascaovulasi dalam menghasilkan progesteron.

Pelepasannya juga periodik/pulsatif, kadarnya dalam darah bervariasi setiap fase siklus, waktu paruh eliminasinya pendek (sekitar 1 jam). Kerja sangat cepat dan singkat. Pada pria LH memicu sintesis testosteron di sel-sel Leydig testis.

\section{ESTEROGEN}

Esterogen dihasilkan oleh ovarium. Ada banyak jenis dari esterogen, tetapi yang paling penting untuk reproduksi adalah estradiol. Esterogen berguna untuk pembentukan ciri-ciri perkembangan seksual pada wanita, yaitu pembentukan payudara, lekuk tubuh, rambut kemaluan dan lain-lain.

Esterogen juga berguna pada siklus menstruasi dengan membentuk ketebalan endometrium, menjaga kualitas dan kuantitas cairan serviks dan vagina sehingga sesuai untuk penestrasi sperma, selain fungsinya yang turut membantu mengatur temperatur suhu (sistem pusat/otak)

Esterogen alami diproduksi terutama oleh sel-sel interna folikel di ovarium secara primer, dan dalam jumlah lebih sedikit juga diproduksi di kelenjar adrenal melalui konversi hormon androgen.

Pada uterus, esterogen menyebabkan proliferasi endometrium; pada serviks menyebabkan perlunakan serviks dan pengentalan lendir serviks; pada vagina menyebabkan proliferasi epitel vagina; dan pada payudara menstimulasi pertumbuhan payudara. Selain itu, estrogen juga mengatur distribusi lemak tubuh.

Pada tulang, estrogen juga menstimulasi osteoblas sehingga memicu pertumbuhan / regenerasi tulang. Pada wanita 
pascamenopause, untuk pencegahan tulang keropos / osteoporosis, dapat diberikan terapi hormon estrogen (sintetik) pengganti.

\section{PROGESTERON}

Hormon ini diproduksi oleh korpus luteum, sebagian diproduksi di kelenjar adrenal, dan pada kehamilan juga diproduksi di plasenta. Progesteron mempertahankan ketebalan endometrium sehingga dapat menerima implantasi zigot. Kadar progesteron terus dipertahankan selama trimester awal kehamilan sampai plasenta dapat membentuk hormon hCG (Human Chorionic Gonadotropin). Progesteron menyebabkan terjadinya proses perubahan sekretorik (fase sekresi) pada endometrium uterus, yang mempersiapkan endometrium uterus berada pada keadaan yang optimal jika terjadi implantasi.

\section{HUMAN CHORIONIC GONADOTROPHIN (HCG)}

Hormon ini diproduksi sejak usia kehamilan 3-4 minggu oleh jaringan trofoblas (plasenta). Kadarnya makin meningkat sampai dengan kehamilan 10-12 minggu (sampai sekitar $100.000 \mathrm{mU} / \mathrm{ml}$ ), kemudian turun pada trimester kedua (sekitar $1.000 \mathrm{mU} / \mathrm{ml}$ ), kemudian naik kembali sampai akhir trimester ketiga (sekitar $10.000 \mathrm{mU} / \mathrm{ml}$ ).

HCG berfungsi meningkatkan dan mempertahankan fumgsi korpus luteum dan produksi hormon-hormon steroid terutama pada masa-masa kehamilan awal. Mungkin juga memiliki fungsi imunologik. Deteksi HCG pada darah atau urine dapat dijadikan sebagai tanda kemungkinan adanya kehamilan (tes Galli Mainini, tes pack, dan sebagainya).

\section{LACTOTROPHIC HORMONE (LTH) / PROLACTIN}


Diproduksi di hipofisis anterior, memiliki aktivitas memicu/meningkatkan produksi dan sekresi air susu oleh kelenjar payudara. Di ovarium, prolaktin ikut mempengaruhi pematangan sel telur dan mempengaruhi fungsi korpus luteum. Pada kehamilan, prolaktin juga diproduksi oleh plasenta (Human Placental Lactogen/HPL).

Fungsi laktogenik/laktotropik prolaktin tampak terutama pada masa laktasi/pascapersalinan. Prolaktin juga memiliki efek inhibisi terhadap GnRH hipotalamus sehingga jika kadarnya berlebihan (hiperprolaktinemia) dapat terjadi gangguan pematangan follikel, gangguan ovulasi, dan gangguan haid berupa amenorea.

\section{Daur Ovarium}

GnRH menginduksi lobus anterior hipofisis untuk memproduksi FSH dan LH pada akhir menstruasi. Melalui peredaran darah, kedua hormon tersebut tiba di ovarium, akan tetapi folikel belum mempunyai reseptor untuk menangkap LH. Hormon FSH menginduksi perkembangan folikel. Menjelang pembentukan folikel de Graaf, sel-sel yang meliputi membran granulosa berkondensasi dan membentuk lapisan, yang disebut teka folikuli interna dan berfungsi sebagai kelenjar endokrin yang menghasilkan hormon estrogen. Di bagian luar dari teka folikel interna sel-sel membentuk teka folikuli eksterna.

Produksi hormon esterogen meninggi dengan cepat mendekati pematangan folikel de Graaf. Konsentrasi hormon esterogen yang tinggi memberikan umpan balik positif terhadap hipotalamus untuk meningkatkan produksi GnRH sehingga produksi FSH dan LH meningkat.

Kini folikel telah dilengkapi dengan reseptor untuk mengikat hormon LH dan peningkatan hormon LH menginduksi pematangan folikel de Graaf dan kemudian mengalami ovulasi. LH mempunyai fungsi mengubah folikel menjadi korpus luteum setelah ovulasi, 
selanjutnya dari korpus luteum bergantung pada ovum yang diovulasi apakah dibuahi oleh spermatozoa atau tidak.

Jika ovum dibuahi (terjadi kehamilan), maka korpus luteum dipertahankan selama 3 sampai 4 bulan. Hormon progesteron yang diproduksi oleh korpus luteum diperlukan untuk mempertahankan endometrium dari uterus agar tidak meluruh pada bulan-bulan pertama kehamilan. Sesudah 4 bulan korpus luteum berdegenerasi dan tidak menghasilkan hormon progesteron lagi. Pada waktu ini plasenta mulai menghasilkan hormon progesteron.

Jika ovum tidak dibuahi, korpus luteum masih dapat bertahan selama kurang lebih 14 hari, dan kemudian berdegenerasi. Sel-sel luteal berubah menjadi jaringan fibrosa berwarna putih, sehingga disebut korpus albikans dan produksi progesteron berhenti.

\section{Daur Menstruasi}

Mulai hari pertama terjadinya perdarahan menses sampai hari pertama perdarahan menses berikutnya dihitung satu daur menstruasi (menses). Daur menstruasi dapat dibagi atas empat fase, yaitu pascamenstruasi, proliferasi, sekretoris dan menstruasi.

\section{Pascamenstruasi}

Stratum kompaktum dan stratum spongiosum dari endometrium telah selesai meluruh (mengelupas atau mengalami erosi) pada waktu menstruasi berhenti. Pada waktu ini konsentrasi hormon estrogen dan hormon progesteron rendah, dan keadaan ini memberikan umpan balik positif bagi hipotalamus untuk meningkatkan produksi hormon $\mathrm{GnRH}$ sehingga produksi FSH dan LH mulai pula dinaikkan. Pascamenstruasi berlangsung kurang lebih empat hari. 


\section{Fase Proliferasi}

Pada fase ini endometrium mulai menebal kembali secara progresif. Penebalan dimungkinkan oleh proliferasi atau perbanyakan sel-sel endometrium di lapisan stratum basalis yang tidak mengalami erosi pada waktu menstruasi. Proliferasi sel diinduksi oleh hormon esterogen yang dihasilkan oleh teka folikuli interna dari folikel yang sedang berkembang menjadi folikel de Graaf. Jadi, sementara folikel berkembang menjadi folikel de Graaf yang diinduksi oleh hormon $\mathrm{FSH}$, endometrium berproliferasi menjadi tebal oleh hormon esterogen. Pada fase proliferasi tidak hanya terjadi penebalan endometrium, akan tetapi terjadi regenerasi kelenjar-kelenjar dan pembuluh darah yang terpotong pada waktu menstruasi. Akhirnya terbentuk lagi stratum kompaktum dan stratum spongiosum dari endometrium. Fase ini berlangsung kurang lebih 12 hari.

\section{Fase Sekresi}

Endometrium mengalami penebalan maksimum pada fase sekresi, yakni mencapai 5 sampai $7 \mathrm{~mm}$ dari hanya 0,5 sampai $1 \mathrm{~mm}$ yang tersisa pada pascamenstruasi. Bagian basal dari kelenjar-kelenjar uterus yang tersisa bertumbuh memanjang dan kemudian berkelok-kelok. Diameter kelenjar bertambah. Sel-sel kelenjar banyak memproduksi glikogen. Pada fase ini bagian apikal sel-sel kelenjar melepaskan diri dan disekresikan ke ruang uterus bersama glikogen dan sekret lain. Sekret berupa lendir berfungsi untuk menerima blastokista jika terjadi fertilisasi.

Setelah ovulasi, hormon LH dari lobus anterior hipofisis menginduksi folikel de Graaf yang tersisa menjadi korpus luteum. Korpus luteum ini memproduksi hormon progesteron. Oleh peredaran darah hormon progesteron tiba di uterus dan menginduksi sekresi kelenjar-kelenjar serta mempertahankan eksistensi tebalnya endometrium, sebagai persiapan untuk 
implantasi dan tempat perkembangan embrio. Pada fase sekretoris berlangsung kurang lebih 8 hari.

\section{Fase Menstruasi}

Jika ovum tidak dibuahi, maka menjelang akhirnya fase sekretoris hormon esterogen dan progesteron makin meningkat. Konsentrasi tinggi dari kedua hormon tersebut memberikan umpan balik negatif bagi hipotalamus sehingga produksi hormon GnRH ditekan dan mengakibatkan penurunan produksi hormon FSH dan LH. Pada waktu LH berkurang, maka korpus luteum yang membutuhkan LH untuk berfungsi mulai berdegenerasi dan berubah menjadi korpus albikans. Hal ini mengakibatkan penurunan konsentrasi hormon esterogen dan progesteron. Karena progesteron berfungsi mempertahankan fase sekretoris dan keutuhan tebalnya endometrium, maka pada waktu konsentrasi hormon progesteron menurun tajam, stratum kompaktum dan stratum spongiosum mengalami erosi. Pembuluh darah terpotong, sehingga terjadi perdarahan. Peristiwa ini disebut dengan menstruasi.

Darah menstruasi tidak berkoagulasi. Erosi endometrium tidak terjadi sekaligus, melainkan setempat demi setempat akhir menstruasi. Stratum basalis yang tersisa bertumbuh kembali pada fase proliferasi daur berikutnya dan fase ini berlangsung kurang lebih empat hari. 


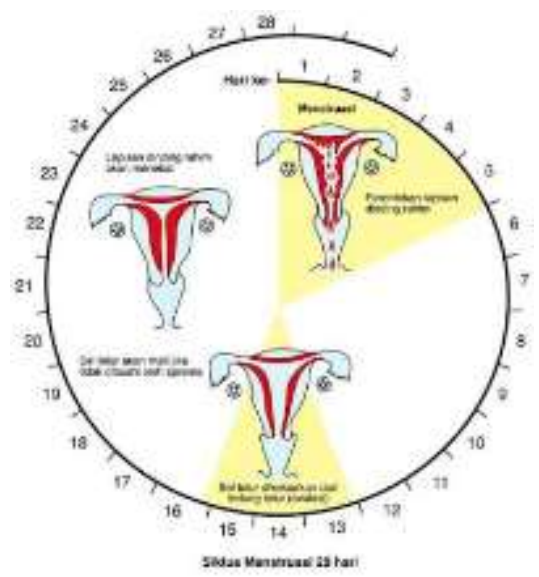

GAMBAR 2-2 Fase menstruasi

\section{Hubungan Ovulasi dengan Daur Menstruasi}

Pada daur menstruasi 28 hari, ovulasi terjadi sekitar pertengahan daur. Jarak waktu antara ovulasi dan permulaan menstruasi berikutnya adalah konstan 14 hari, akan tetapi waktu antara ovulasi tersebut dengan permulaan menstruasi sebelumnya tidak konstan. Hal ini terjadi oleh karena panjangnya daur menstruasi dapat bervariasi dari bulan ke bulan pada individu yang sama. Oleh karena itu, sulit memprediksi tanggal ovulasi berikutnya dihitung mulai dari tanggal permulaan menstruasi, kecuali jika wanita memperlihatkan periode menstruasi yang sangat teratur.

Salah satu metode untuk mengetahui waktu ovulasi adalah dengan metode pengukuran suhu. Suhu tubuh wanita diukur setiap pagi. Suhu menjadi rendah selama menstruasi, kemudian akan naik. Pada kira-kira pertengahan daur, tiba-tiba suhu turun dan diikuti oleh kenaikan suhu. Turun dan menaiknya suhu menandakan terjadinya ovulasi. Selain pengukuran suhu tubuh untuk mengetahui waktu ovulasi adalah dengan indikator berupa sifat lendir serviks. 


\section{Perubahan Hormonal Setelah Fertilisasi.}

Setelah implantasi, zigot mensekresikan human chorionic gonadotropin (HCG), yang serupa dengan LH dan menimbulkan efek yang sama. HCG ini menyebabkan korpus luteum terus berproliferasi dan mensekresikan kadar progesteron yang semakin meningkat, sehingga endometrium dipertahankan. Hal inilah yang menyebabkan berhentinya daur menstruasi. 


\section{BAB 3}

GAMETOGENESIS, FERTILISASI, DAN IMPLANTASI

\subsection{GAMETOGENESIS}

Gametogenesis merupakan proses terbentuknya gamet atau sel kelamin. Gametogenesis pada pria dinamakan spermatogenesis yang merupakan proses pembentukan sel kelamin pria (spermatozoa) dan gametogenesis pada wanita yang dinamakan oogenesis yaitu proses pembentukan sel kelamin wanita (ovum).

\section{Spermatogenesis.}

Sperma manusia berbentuk seperti kecebong dengan pembagian sebagai berikut :

1. Kepala, berbentuk lonjong agak gepeng berisi nukleus (inti) haploid tebal dengan sedikit sitoplasma, bagian ujungnya diselubungi oleh akrosom yang berfungsi menghasilkan enzimenzim yang membantu sperma dalam menembus ovum. Panjang bagian kepala sekitar $5 \mu \mathrm{m}$.

2. Leher, yang menghubungkan kepala dengan bagian tengah.

3. Bagian tengah, yang banyak mengandung mitokondria sebagai penghasil energi (ATP) untuk pergerakan sperma. Panjang bagian tengah sekitar $5 \mu \mathrm{m}$.

4. Ekor, yang berupa flagela sebagai alat pergerakan sperma. Ekor ini dibagi lagi menjadi bagian utama (principal piece) dengan panjang sekitar $50 \mu \mathrm{m}$ dan bagian ujung (end piece) dengan panjang sekitar $5 \mu \mathrm{m}$.

Spermatogenesis berlan£ -.... di dalam testis, tepatnya di dalam duktus seminiferus. Pada mulanya, di dalam tubulus 
seminiferus embrio laki-laki hanya ada 2 macam sel, yakni sel induk atau sel punca (stem cell) besar yang akan berproliferasi secara mitosis membentuk spermatogonia, dan sel kecil yang belum berspesialisasi. Pada waktu spermatogenesis berlangsung, sebagian sel tetap berupa sel punca sedang yang lain berdiferensiasi selama pembelahan meiosis.

Pada masa pubertas, spermatogenesis berlanjut dimana spermatogonia berproliferasi menghasilkan semakin banyak spermatogonia yang masing-masing mengandung 23 pasang kromosom atau diploid $(2 \mathrm{n}=46$ kromosom). Beberapa spermatogonia berdiferensiasi menjadi spermatosit primer yang juga diploid. Sel-sel spermatosit primer tersebut kemudian membelah secara meiosis menjadi dua spermatosit sekunder dengan jumlah kromosom menjadi setengahnya yaitu 23 kromosom atau haploid (n). Selanjutnya spermatosit sekunder membelah lagi secara meiosis menjadi empat spermatid. Keempat spermatid ini memasuki ujung sel-sel Sertoli untuk mematangkan diri menjadi spermatozoa yang merupakan tahap akhir dari proses pembentukan sperma. Tahap tahap ini bermula dari bagian dalam dinding luar duktus seminiferus menuju ke arah lumen, mengandung sel spermatogonia, spermatosit primer, spermatosit sekunder, spermatid serta spermatozoa.

Proses pematangan spermatid menjadi spermatozoa disebut spermiogenesis yang terjadi di dalam epididimis. Spermiogenesis terbagi menjadi 4 fase, yaitu fase Golgi, fase tutup (cap), fase akrosom, dan fase pematangan. Pada proses ini sebagian badan golgi menjadi akrosom yang menutupi bagian apikal kepala. Sitoplasma didorong dari kepala ke ekor sehingga hanya sedikit yang tersisa membungkus ekor, sedang sebagian besar sitoplasma dibuang. 


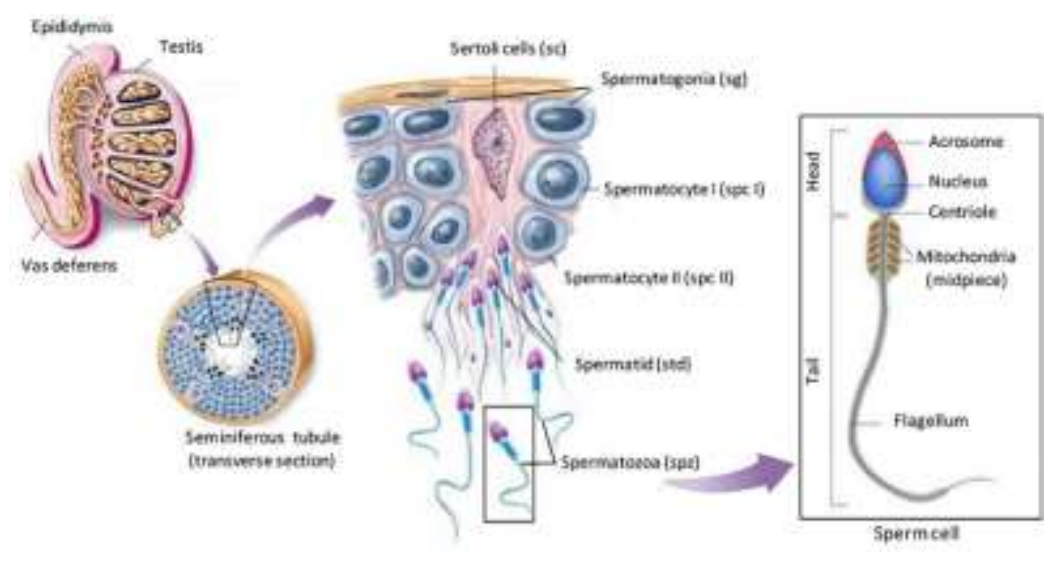

GAMBAR 3-1 Spermatogenesis

\section{Oogenesis}

Meskipun adanya persamaan antara spermatogenesis dengan oogenesis, yaitu keduanya mengalami pembelahan meiosis, akan tetapi rincian proses dan produksinya sangat berbeda. Perbedaan ini berkolerasi dengan fungsi terspesialisasi dari kedua jenis gamet tersebut. Spermatozoa harus dapat bergerak dan mendatangi ovum di dalam saluran reproduksi, sedangkan ovum harus mengandung substansi nutrisi untuk embrio yang akan terbentuk setelah terjadi fertilisasi sehingga volume ovum besar dan pasif tidak dapat bergerak sendiri.

Ovum merupakan salah satu sel terbesar dalam tubuh manusia, dengan ukuran sekitar 0,2 $\mathrm{mm}$ dan tertutup dalam folikel telur dari indung telur. Ovum dilingkari oleh zona pelusida dan dilapisi oleh korona radiata.

Ovum pada waktu diovulasi dari ovarium adalah ovum yang belum matang dan berada dalam stadium oosit sekunder (haploid/ $\mathrm{n}$ kromosom) hasil pembelahan meiosis I. Oosit sekunder baru dapat melanjutkan meiosis II jika diinduksi oleh penetrasi spermatozoa pada waktu fertilisasi. 
Zona pelusida melindungi ovum dan sel-sel korona radiata menempatkan diri secara radial di bagian luar zona pelusida. Membran nukleus telah melarut (hilang) menjelang pembelahan meiosis II. Diantara membran sel ovum (membran vitelinus) dan zona pelusida tampak polosit primer (badan polar I) hasil pembelahan meiosis.

Oogenesis dimulai di dalam embrio perempuan, yang menghasilkan oogonium dari sel punca (stem cell) primordial. Oogonium membelah secara mitosis untuk membentuk oosit primer yang telah ada sejak masa bayi, tetapi tertahan perkembangannya sampai masa pubertas tiba. Oosit primer ini terkandung di dalam folikel kecil. Oosit primer mengandung 23 pasang kromosom atau diploid ( $2 \mathrm{n}=46$ kromosom).

Saat pubertas hormon FSH akan merangsang folikel untuk melanjutkan perkembangannya dan oosit primer melakukan pembelahan meiosis I menghasilkan satu sel oosit sekunder yang besar dan satu sel polosit primer (badan polar pertama) yang lebih kecil. Perbedaan ini disebabkan sel oosit sekunder mengandung hampir semua sitoplasma dan kuning telur, sedangkan sel polosit hanya terdiri dari nukleus saja. Oosit sekunder ini mempunyai kromosom setengah kromosom oosit primer yaitu 23 kromosom atau haploid (n).

Oosit sekunder akan dilepaskan saat ovulasi. Jika ada sperma yang berhasil menembusnya, oosit sekunder akan menjalani meiosis II menghasilkan satu sel ootid yang besar dan satu polosit sekunder (badan polar kedua). Ootid yang besar tersebut mengandung hampir semua kuning telur dan sitoplasma. Pada saat yang sama, polosit primer membelah diri menjadi dua (bisa juga tidak membelah). Selanjutnya ootid berdiferensiasi menjadi ovum yang mempunyai 23 kromosom (haploid). Sementara itu ketiga polosit kecil hancur, sehingga setiap oosit primer hanya menghasilkan satu ovum yang fungsional. Ovum yang besar itu 
mengandung sumber persediaan makanan, ribosom, RNA dan komponen-komponen sitoplasma lain yang berperan dalam perkembangan embrio. Ovum yang matang diselubungi oleh korona radiata dan zona pelusida.

Oogenesis terjadi di dalam ovarium hanya berlangsung hingga seorang wanita berusia 40 sampai 50 tahun. Setelah wanita tidak mengalami menstruasi lagi (menopause) ovum tidak diproduksi lagi.

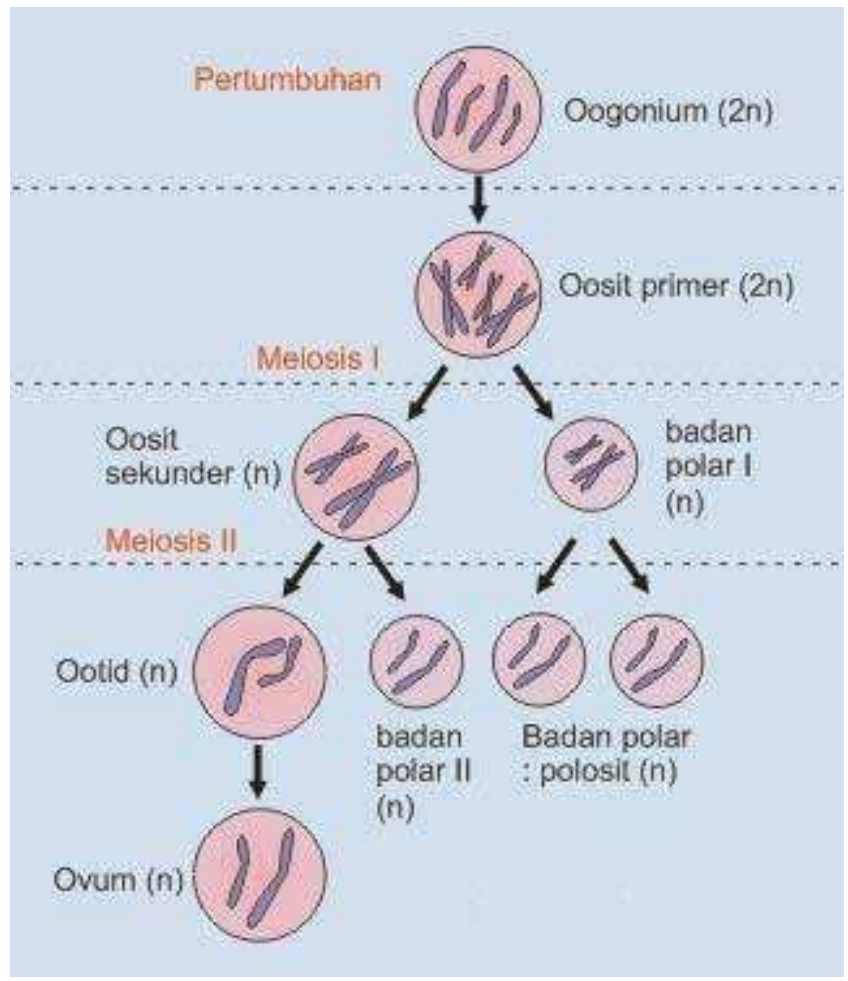

GAMBAR 3-2 Oogenesis

\section{Pembelahan Folikel}

Sel-sel bakal telur telah terbentuk oleh proliferasi sel-sel lapisan epitelium germinal yang meliputi ovarium di dalam periode perkembangan janin perempuan di dalam uterus ibunya. Bakal sel 
telur melepaskan diri dari lapisan epitelium germinal dan terbenam di dalam bagian korteks dari ovarium. Di sana bakal sel telur berproliferasi membentuk oogonium. Sel-sel yang berada di sekitar oogonium mengatur diri di sekelilingi oogonium untuk memberikan perlindungan dan penyalur makanan bagi oogonium, membentuk folikel primer. Sel-sel folikel di sekitar oogonium cepat berproliferasi menjadi beberapa lapis. Sementara itu terjadi ruangan-ruangan di antara sel-sel folikel, disebut antrum folikuli yang diisi oleh cairan likuor folikuli. Keseluruhan folikel yang terbenam dalam korteks ovarium kini mulai berkembang ke arah permukaan ovarium. Setelah matang, folikel menonjol keluar dari permukaan ovarium dan siap mengalami ovulasi. Folikel yang sudah matang ini disebut folikel de Graaf.

Pada tingkat ini ovum berada dalam stadium oosit primer. Sitoplasmanya sudah mengandung substansi nutrisi sehingga oosit primer bertambah besar. Ovum diliputi oleh suatu lapisan substansi nonselular yang trasnparan disebut zona pelusida. Di luar zona pelusida sel-sel folikel mengatur diri secara radial membentuk korona radiata. Lapisan sel-sel folikel yang bergerombol di daerah perifer dari dinding folikel disebut stratum granulosum. Jaringan pengikat di luar stratum granulosum berkondensasi membentuk teka folikuli. Pada folikel de Graaf ovum dan sel-sel folikel yang meliputinya menonjol ke dalam antrum folikuli dan membentuk kumulus ooforus.

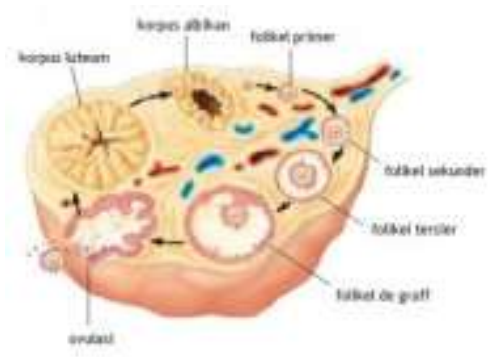




\section{Ovulasi}

Dengan bertambahnya likuor folikuli di dalam folikel de Graaf dan tekanan ke dalam oleh teka folikuli, maka bagian yang menonjol keluar dari ovarium pecah, sehingga ovum bersama korona radiata serta likuor folikuli terlempaar/tersembur keluar dan ditampung oleh tuba Fallopi (oviduk). Proses ini disebut ovulasi.

\section{Korpus Luteum}

Sel-sel folikel yang tersisa di dalam ovarium setelah ovulasi dan teka folikuli membentuk korpus luteum. Pada saat terjadi ovulasi, beberapa pembuluh darah kapiler di sekitar folikel putus sehingga sedikit darah tercurah ke dalam bekas antrum folikuli (terjadi korpus rubrum). Eritrosit difagositosis oleh leukosit untuk digantikan oleh suatu substansi berwarna kuning, sehingga keseluruhannya disebut korpus luteum. Korpus luteum berfungsi sebagai kelenjar endokrin yang memproduksi hormon. Hormon ini berfungsi mempersiapkan dinding endometrium uterus untuk menerima embrio nanti. Jika terjadi fertilisasi, korpus luteum dipertahankan akan tetapi jika tidak terjadi fertilisasi, korpus luteum berdegenerasi. Sel-sel folikel berdegenerasi dan diganti oleh jaringan pengikat berwarna keputihan sehingga kini disebut korpus albikans.

\section{Folikel Atresia}

Tidak semua folikel primer yang terbentuk berkembangh menjadi folikel yang matang (folikel de Graaf). Sebagian besar berhenti bertumbuh dan mulai berdegenerasi disebut folikel atresia. Pada janin manusia berusia 5 bulan terdapat kurang lebih 7 juta folikel primer dan pada waktu bayi lahir hanya tersisa 2 juta folikel 
primer (yang lain mengalami atresia) dan pada waktu masa puber hanya terdapat kurang dari 200.000 folikel yang aktif.

\section{Pematangan Ovum}

Oogonium membesar menjadi oosit primer atau oosit I, sedangkan oosit sekunder merupakan oosit primer yang kemudian mengalami pembelahan meiosis I menghasilkan 2 anak sel dimana sitoplasma terkonsentrasi pada salah satu anak sel yang besar. Oosit sekunder disebut juga oosit II (n kromosom). Anak sel lain yang kecil, disebut polosit primer atau badan polar I, kemudian berdegenerasi meskipun ada juga yang dapat membelah pada meiosis kedua menghasilkan dua polosit. Sementara itu, oosit sekunder mengalami pembelahan meiosis II menghasilkan 2 anak sel yang tidak sama besar. Anak sel yang besar mengandung sitoplasma banyak disebut ootid dan akan menjadi ovum matang yang siap dibuahi. Anak sel yang kecil disebut polosit sekunder atau badan pola II akan berdegenerasi. Polosit primer dan polosit sekunder tidak berperan dalam fertilisasi dan akhirnya berdegenerasi. Meiosis II berlanjut setelah dirangsang oleh penetrasi spermatozoa pada waktu fertilisasi.

\section{Masa Diktioten}

Oosit primer pada manusia terhenti perkembangannya pada stadium profase dari meiosis primer sampai saatnya diovulasi. Tenggang waktu ini disebut masa diktioten. Karena pada umumnya setiap bulan hanya satu folikel de Graaf yang mengalami ovulasi, maka ada oosit primer yang mengalami masa diktioten lebih dari 40 tahun menjelang masa menopause. Pada waktu menopause semua pembelahan meiosis terhenti, sehingga tidak ada lagi ovum yang diproduksi. 


\subsection{PROSES KEHAMILAN}

\section{FERTILISASI}

Penyatuan ovum (oosit sekunder) dan spermatozoa yang biasanya berlangsung di ampula tuba dinamakan fertilisasi. Fertilisasi mempunyai dua fungsi utama yaitu :

1. Fungsi reproduksi, yang memungkinkan pemindahan unsurunsur genetik dari orang tua kepada keturunan. Jika pada gametogenesis terjadi reduksi ( $2 n$ menjadi $n$ ) unsur genetik, maka fertilisasi terjadi penggabungan unsur genetik (pemulihan kembali dari $n$ menjadi $2 \mathrm{n}$, masing-masing orang tua menyumbang $n$ ). Tanpa fertilisasi (kecuali pada kasus-kasus tertentu) kesinambungan keturunan suatu spesies tidak akan terjadi.

\section{Fungsi perkembangan}

Ketika fertilisasi memicu oosit sekunder untuk melanjutkan dan menyelesaikan proses pembelahan meiosisnya dan membentuk pronukleus wanita. Pronukleus wanita ini yang akan melebur (syngami) dengan pronukleus pria (berasal dari nukleus spermatozoa) untuk membentuk zigot. Jika fertilisasi tidak terjadi maka oosit sekunder akan tertahan pada tahap metafase meiosis II dan kemudian berdegenerasi.

Fertilisasi memerlukan oosit sekunder (ovum) yang telah masak dan siap dibuahi. Sebelumnya ovum ini dikeluarkan dari ovarium pada proses yang dinamakan ovulasi pada sekitar hari ke-14 dari daur menstruasi. Fimbriae pada ujung tuba fallopi meliputi 
ovarium, sehingga ovum yang diovulasi mudah ditampung di infundibulum. Ovum kemudian didorong oleh tuba fallopi (tuba uterina, disebut juga oviduk) ke arah lumen uterus oleh aktivitas silia pada lumen tuba fallopi, gerak peristaltik tuba fallopi, cairan yang dikeluarkan oleh sel-sel dan beberapa sebab lain. Jika pada waktu ini terjadi hubungan kelamin (sexual intercourse), spermatozoa yang dilepas di liang vagina berenang ke dalam uterus dan melanjutkan perjalanan ke dalam tuba fallopi.

Seorang wanita disebut hamil jika sel telur berhasil dibuahi oleh sel sperma laki-laki. Hasil pembuahan akan menghasilkan zigot, kemudian berkembang (dengan cara pembelahan sel secara besarbesaran) menjadi embrio. Pembuahan itu sendiri berlangsung setelah terjadinya hubungan seksual antar-lawan jenis, meskipun tidak semua hubungan seksual akan menghasilkan pembuahan. Pembuahan hanya dapat terjadi ketika wanita sedang dalam masa subur. Pada masa itu, seorang wanita akan melepaskan sel telur yang sudah matang dan siap dibuahi.

Dalam keadaan normal, seorang pria akan mengeluarkan jutaan sperma saat melakukan persetubuhan. Menurut perhitungan dalam satu ejakulasi terdapat 200 sampai 300 juta spermatozoa yang disemprotkan ke dalam liang vagina, akan tetapi hanya sekitar 300 sampai 500 spermatozoa yang berhasil mencapai ampula dan hanya satu yang akan berhasil membenamkan diri ke dalam dinding sel telur yang sudah masak dan menyatukan dua inti sel. Sebagian besar sperma yang berjalan dari vagina menuju uterus dan masuk ke tuba fallopi dihancurkan oleh mukus (lendir) di dalam uterus dan tuba. Sel yang telah dibuahi akan membelah diri. Mula-mula menjadi 2 lalu 4,8,16 dan seterusnya. Seminggu setelah pembuahan, kelompok sel yang terus tumbuh itu telah sampai di dalam rongga rahim dan melekatkan diri di dinding rahim. 
Untuk mendukung aktivitas sperma, ovum mengeluarkan senyawa fertilizin yang tersusun dari glikoprotein yang berfungsi untuk :

1. Mengaktifkan sperma agar bergerak lebih cepat.

2. Menarik sperma secara kemotaksis positif.

3. Mengumpulkan sperma di sekeliling ovum.

Di sisi lain, akrosom di bagian kepala sperma menghasilkan enzim-enzim yang membantu sperma dalam menembus ovum, yaitu (1) hialuronidase, enzim yang dapat melarutkan hialuronid pada sel-sel korona radiata, (2) akrosin, enzim protease yang dapat menghancurkan glikoprotein pada zona pelusida, dan (3) anti-fertilizin, antigen terhadap ovum (oosit sekunder) sehingga sperma dapat melekat pada ovum.

Bila berlangsung normal, proses kehamilan akan berjalan terus sampai janin siap untuk dilahirkan ke dunia. Tahap - tahap kehamilan dapat dibagi menjadi tiga trimester, yaitu trimester pertama, kedua dan ketiga. Trimester pertama adalah trimester yang sangat menentukan karena pada saat inilah pembentukan organ vital telah dimulai, termasuk pembentukan dan perkembangan otak. Akan tetapi, tentu saja trimester lain pun punya peranan penting dan harus dijaga dengan baik.

Pada saat kopulasi antara pria dan wanita (senggama/koitus), ejakulasi sperma dari saluran reproduksi pria di dalam vagina wanita, akan melepaskan cairan mani berisi sel-sel sperma ke dalam saluran reproduksi wanita. Jika senggama terjadi dalam sekitar masa ovulasi (disebut "masa subur" wanita), maka ada kemungkinan sel sperma dalam saluran reproduksi wanita akan bertemu dengan sel telur yang baru dikeluarkan pada saat ovulasi. Pertemuan/penyatuan sel sperma dengan sel telur inilah yang disebut sebagai pembuahan atau fertilisasi. 
Dalam keadaan normal in vivo, pembuahan terjadi di daerah tuba fallopi, yang umumnya di daerah ampula/infundibulum. Perkembangan teknologi kini memungkinkan penatalaksanaan kasus infertilitas (tidak bisa mempunyai anak) dengan cara mengambil oosit wanita dan dibuahi dengan sperma pria di luar tubuh, kemudian setelah terbentuk embrio, embrio tersebut dimasukkan kembali ke dalam rahim untuk pertumbuhan selanjutnya. Teknik ini disebut sebagai pembuahan in vitro (in vitro fertilization-IVF) dalam istilah awam disebut bayi tabung.

Spermatozoa bergerak cepat dari vagina ke dalam rahim, masuk ke dalam tuba. Gerakan ini mungkin dipengaruhi juga oleh peranan kontraksi miometrium dan dinding tuba yang juga terjadi saat senggama. Kemudian spermatozoa mengalami peristiwa sebagai berikut :

1. Reaksi kapasitasi : selama beberapa jam, protein plasma dan glikoprotein yang berada dalam cairan mani diluruhkan.

2. Reaksi akrosom : setelah dekat dengan oosit, sel sperma yang telah menjalani kapasitasi akan terpengaruh oleh zat-zat dari korona radiata ovum sehingga isi akrosom dari daerah kepala sperma akan terlepas dan berkontak dengan lapisan korona radiata.

Pada saat ini dilepaskan hialuronidase yang dapat melarutkan korona radiata, trypsine-like agent dan lysine-zone yang dapat melarutkan serta membantu sperma melewati zona pellucida untuk mencapai ovum.

Sekali sebuah spermatozoa menyentuh zona pellucida, terjadi perlekatan yang kuat dan penembusan yang sangat cepat. Sekali telah terjadi penembusan zona oleh satu sperma, terjadi reaksi khusus di zona pellucida (zone-reaction) yang bertujuan mencegah terjadinya penembusan lagi oleh sperma lainnya. Dengan demikian sangat jarang sekali terjadi penembusan zona oleh lebih dari satu sperma. 
Setelah sel sperma mencapai oosit, terjadi hal-hal berikut ini :

1. Reaksi zona/reaksi kortikal pada selaput zona pellucida.

2. Oosit menyelesaikan pembelahan meiosis keduanya, menghasilkan oosit definitif yang kemudian menjadi pronukleus wanita.

3. Inti sel sperma membesar membentuk pronukleus pria.

4. Ekor sel sperma terlepas dan berdegenerasi.

5. Pronukleus pria dan wanita, masing-masing haploid, bersatu dan membentuk zigot yang memiliki DNA genap/diploid.

Hasil utama pembuahan adalah sebagai berikut :

1. Penggenapan kembali jumlah kromosom dari penggabungan dua paruh haploid dari ayah dan dari ibu menjadi suatu bakal individu baru dengan jumlah kromosom diploid.

2. Penentuan jenis kelamin bakal individu baru, tergantung dari kromosom $\mathrm{X}$ atau $\mathrm{Y}$ yang dikandung oleh sperma yang membuahi ovum tersebut.

3. Permulaan pembelahan dan stadium-stadium pembentukan dan perkembangan embrio (embriogenesis).

\section{Tahap Fertilisasi}

Fertilisasi terjadi melalui 4 tahap yaitu :

1. Penetrasi korona radiata, oleh sperma dengan bantuan enzim hialuronidase yang melarutkan senyawa hialuronid pada korona radiata.

2. Penetrasi zona pelusida, oleh sperma dengan bantuan enzim akrosin untuk menghancurkan glikoprotein. Penetrasi ini memicu sel-sel granulosit di bagian korteks oosit sekunder untuk mengeluarkan senyawa tertentu yang menyebabkan selsel di zona pelusida berikatan satu sama lain membentuk suatu materi yang keras dan tidak dapat ditembus oleh sperma lain. 
Proses ini mencegah ovum dibuahi oleh lebih dari satu sperma (polispermia).

3. Setelah menembus zona pelusida, spermatozoa masuk ke ruang perivitelin (ruang antara zona pelusida dengan membran vitelin/membran plasma), kemudian menempel dan terjadi fusi (peleburan) membran spermatozoa dengan membran plasma oosit. Peleburan ini memungkinkan nukleus spermatozoa masuk sitoplasma, kemudian berkondensasi dan membesar sehingga menjadi pronukleus pria (n). Sedangkan ekor spermatozoa kemudian terlepas dan berdegenerasi. Akibat masuknya nukleus spermatozoa ini juga mengaktivasi oosit sekunder menyelesaikan pembelahan meiosis kedua-nya menjadi ootid dan polosit sekunder (badan polar II) sedangkan nukleusnya berkondensasi menjadi pronukleus wanita (n).

4. Kedua pronukleus bergerak ke tengah, lalu terjadi fusi (peleburan) pronukleus wanita dan pronukleus pria (disebut syngami). Peleburan ini mengembalikan jumlah kromosom dari haploid menjadi diploid dan sel baru hasil peleburan ini disebut zigot (2n).

\section{Implantasi}

Pada akhir minggu pertama (hari ke-5 sampai hari ke-7) zigot mencapai kavum uteri. Pada saat itu, uterus sedang berada dalam fase sekresi lendir di bawah pengaruh progesteron dari korpus luteum yang masih aktif sehingga lapisan endometrium dinding rahim menjadi kaya pembuluh darah dan banyak muara kelenjar selaput lendir rahim yang terbuka dan aktif.

Kontak antara zigot stadium blastokista dengan dinding rahim pada keadaan tersebut akan mencetuskan berbagai reaksi seluler sehingga sel-sel trofoblas zigot tersebut dapat menempel dan mengadakan infiltrasi pada lapisan epitel endometrium uterus (terjadi implantasi). 
Setelah implantasi, sel-sel trofoblas yang tertanam di dalam endometrium terus berkembang, membentuk jaringan bersama dengan sistem pembuluh darah maternal untuk menjadi plasenta, yang kemudian berfungsi sebagai sumber nutrisi dan oksigenasi bagi jaringan embrioblas yang akan tumbuh menjadi janin.

Peristiwa utama pada terjadinya kehamilan adalah :

1. Fertilisasi atau pembuahan, yaitu bertemunya sel telur (ovum) wanita dengan sel sperma (spermatozoa) pria.

2. Pembelahan sel pada hasil fertilisasi tersebut (zigot).

3. Nidasi atau implantasi zigot pada dinding saluran reproduksi. Pada keadaan normal, implantasi terjadi pada lapisan endometrium dinding kavum uteri.

Kehamilan dipengaruhi berbagai hormon, diantaranya estrogen, progesteron, hCG (human charionic gonadotropin), human charionic somatomammotropin, prolaktin dan sebagainya. hCG merupakan hormon aktif khusus yang berperan selama awal masa kehamilan, berfluktuasi kadarnya selama masa kehamilan.

Anatomi dan fisiologi organ-organ sistem reproduksi dan organ-organ tubuh lainnya pada wanita hamil mengalami perubahan, dipengaruhi terutama oleh perubahan keseimbangan hormon-hormon tersebut.

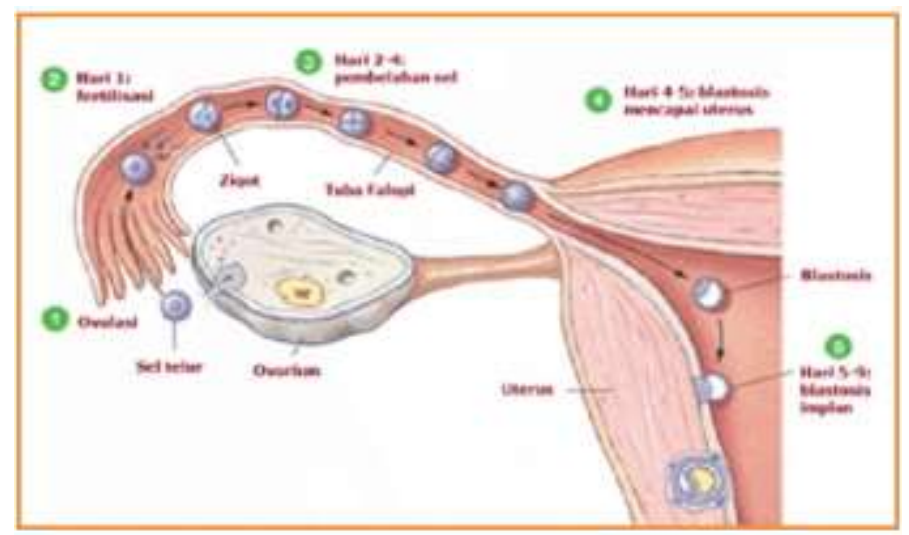


GAMBAR 3-5 Dari fertilisasi hingga implantasi

\section{Perubahan pada Organ-Organ Sistem Reproduksi}

\section{Uterus}

Uterus akan tumbuh membesar, primer maupun sekunder, akibat pertumbuhan isi konsep intrauterin. Estrogen dapat menyebabkan hiperplasia pada jaringan, hormon progesteron berperan untuk elastisitas/kelenturan uterus.

Taksiran kasar perbesaran uterus pada perabaan tinggi fundus adalah :

- Tidak hamil/normal : sebesar telur ayam ( \pm 30 gram).

- Kehamilan 8 minggu : telur bebek.

- Kehamilan 12 minggu : telur angsa.

- Kehamilan 16 minggu : pertengahan simfisis pusat.

- Kehamilan 20 minggu : pinggir bawah pusat.

- Kehamilan 24 minggu : pinggir atas pusat.

- Kehamilan 28 minggu : sepertiga pusat xyphoid.

- Kehamilan 32 minggu : pertengahan pusat xyphoid.

- Kehamilan 36-42 minggu : 3 sampai 1 jari bawah xyphoid.

Ishmus uteri, bagian dari serviks dan batas anatomiknya menjadi sulit ditentukan. Pada kehamilan trimester I, isthmus uteri memanjang dan lebih kuat. Pada kehamilan 16 minggu isthmus uteri menjadi satu bagian dengan korpus, dan pada kehamilan akhir di atas 32 minggu menjadi segmen bawah uterus. Pada isthmus vaskularisasi sedikit, lapisan muskular tipis, mudah ruptur, kontraksi minimal berbahaya jika lemah, mengancam nyawa janin dan ibu, dan dapat ruptur.

Serviks uteri, akibat stimulasi esterogen dan perlunakan akibat progesteron (tanda Hegar) mengalami hipervaskularisasi, warna 
menjadi livide/kebiruan. Sekresi lendir serviks meningkat pada kehamilan dan memberikan gejala keputihan.

Vagina/Vulva, akibat pengaruh esterogen dan progesteron sehingga terjadi hipervaskularisasi, warna merah kebiruan (Tanda Chadwick).

Ovarium, fungsi ovarium diambil alih oleh plasenta sejak usia kehamilan 16 minggu terutama fungsi produksi progesteron dan estrogen. Selama kehamilan, ovarium tenang/ beristirahat. Tidak terjadi pembentukan dan pematangan folikel baru, tidak terjadi ovulasi, tidak terjadi daur hormonal menstruasi.

Payudara, terjadi hiperplasia sistem duktus dan jaringan interstisial payudara akibat pengaruh estrogen. Hormon laktagenik plasenta (diantaranya somatomammotropin) menyebabkan hipertrofi dan pertambahan sel-sel asinus payudara serta meningkatnya produksi zat-zat kasein, laktoalbumin, laktoglobulin, sel-sel lemak, dan kolostrum. Kelenjar mammae membesar dan tegang, terjadi hiperpigmentasi kulit serta hipertrofi kelenjar Montgomery, terutama di daerah aerola dan papila akibat pengaruh melanofor. Puting susu membesar dan menonjol.

\subsection{TUMBUH KEMBANG FETUS}

\section{Proses Pertumbuhan Embriogenesis}

Zigot mulai tumbuh menjalani pembelahan awal mitosis sampai beberapa kali. Sel-sel yang dihasilkan dari setiap pembelahan berukuran lebih kecil dari ukuran induknya, disebut blastomer. Sesudah 3-4 kali pembelahan : zigot memasuki tingkat 16 sel, disebut stadium morula (kira-kira pada hari ke-3 sampai ke-4 pascafertilisasi). Morula terdiri atas inner cell mass (kumpulan selsel di sebelah dalam, yang akan tumbuh menjadi jaringan-jaringan embrio sampai janin) dan outer cell mass (lapisan sel di sebelah luar, yang akan tumbuh menjadi trofoblas sampai plasenta). 
Kira-kira pada hari ke-5 sampai ke-6, di rongga sela-sela inner cell mass merembes cairan menembus zona pellucida, membentuk ruang antar-sel. Ruang antar-sel ini kemudian bersatu dan memenuhi sebagian besar massa zigot membentuk rongga blastokista.

Inner cell mass tetap berkumpul di salah satu sis, tetap berbatasan dengan lapisan sel luar. Pada stadium ini zigot disebut berada dalam stadium blastula atau pembentukan blastokista.

Inner cell mass kemudian disebut sebagai embrioblas, dan outer cell mass kemudian disebut sebagai trofoblas.

Supaya janin tumbuh dan berkembang dengan sempurna, dibutuhkan penyaluran darah yang membawa oksigen, asam amino, vitamin, dan mineral dari ibu ke janin. Di samping itu, diperlukan pula pembuangan karbon dioksida dan limbah metabolisme dari janin ke sirkulasi ibu. Beberapa istilah berkenaan dengan fungsi tersebut adalah :

Nutrisi

: pemberian makan pada janin.

Respirasi

: penyaluran oksigen, pembuangan $\mathrm{CO}_{2}$.

Ekskresi

: pengeluaran sampah metabolisme.

Produksi

: pembuatan hormon-hormon.

Imunisasi

: penyaluran bermacam-macam antibodi ke janin.

Pertahanan : penyaringan obat-obatan dan kuman melalui urine.

\section{Air Ketuban (Cairan Amnion)}




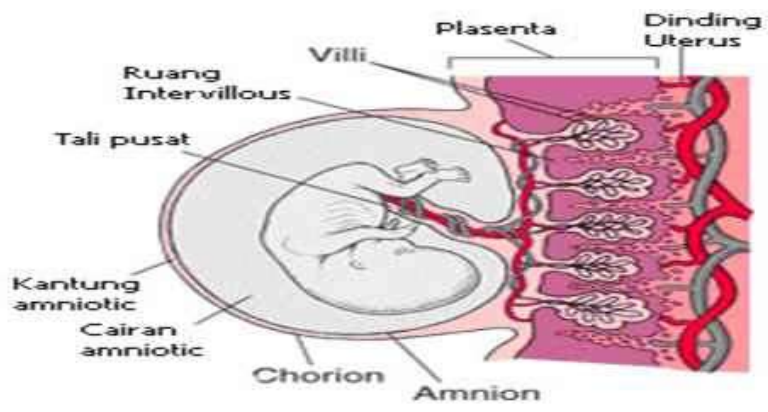

GAMBAR 3-6 Plasenta, tali pusat, selaput janin dan cairan amnion

Rongga yang diliputi selaput janin disebut sebagai rongga amnion. Di dalam ruangan ini terdapat cairan amnion (likour amnii). Asal cairan amnion diperkirakan terutama disekresi oleh dinding selaput amnion/plasenta, kemudian setelah sistem urinarius janin terbentuk, urine janin yang diproduksi juga dikeluarkan ke dalam rongga amnion.

Berikut adalah beberapa fungsi dari cairan amnion :

1. Proteksi : melindungi janin terhadap trauma dari luar.

2. Mobilisasi : memungkinkan ruang gerak bagi janin.

3. Homeostasis: menjaga keseimbangan suhu dan lingkungan asam-basa $(\mathrm{pH})$ dalam rongga amnion, untuk suasana lingkungan yang optimal bagi janin.

4. Mekanik : menjaga keseimbangan tekanan dalam seluruh ruangan intrauterin (terutama pada persalinan)

5. Pada persalinan : membersihkan / melicinkan jalan lahir, dengan cairan yang steril sehingga melindungi bayi dari kemungkinan infeksi jalan lahir.

Keadaan normal cairan amnion memiliki karakteristik sebagai berikut :

1. Pada usia kehamilan cukup bulan, volume 1.000-1.500 cc. 
2. Keadaan jernih agak keruh.

3. Steril.

4. Bau khas, agak manis, dan amis.

5. Terdiri atas $98-99 \%$ air, 1-2 \% garam-garam anorganik dan bahan organik (protein terutama albumin), runtuhan rambut lanugo, vernix caseosa, dan sel-sel epitel.

6. Sirkulasi sekitar $500 \mathrm{cc} / \mathrm{jam}$.

Peredaran air ketuban dengan darah ibu cukup lancar dan perputarannya cepat, kira-kira adalah 350-500 cc. Air ketuban ini berasal dari urine janin, transudat darah ibu, sekret epitel amnion dan campuran ketiganya.

\section{Kelainan Jumlah Cairan Amnion}

Hidramnion (Polihidramnion) adalah air ketuban yang berlebihan, yaitu di atas $2.000 \mathrm{cc}$. Keadaan ini dapat mengarahkan kecurigaan adanya kelainan kongenital susunan saraf pusat atau sistem pencernaan, gangguan sirkulasi, atau hiperaktivitas sistem urinarius janin.

Oligodramnion adalah air ketuban sedikit, di bawah 500 cc. Umumnya kental, keruh, berwarna kuning kehijauan. Prognosis bagi janin buruk.

\section{Pertumbuhan Plasenta}

\section{Pembentukan Plasenta}

Pada minggu-minggu pertama perkembangan, vili meliputi seluruh permukaan korion. Semakin tua kehamilan, vili pada kutub embrional terus tumbuh dan meluas, sehingga membentuk korion frondosum (korion bervili lebat seperti semak-semak). Vili pada 
kutub abembrional mengalami degenerasi, dan pada bulan ketiga sisi korion ini menjadi halus dan disebut korion laeve.

Perbedaan korion di kutub embrional dan abembrional juga tercermin pada susunan desiduanya, yang merupakan lapisan fungsional endometrium dan mengelupas pada saat persalinan. Desidua di atas korion frondosum, desidua basalis, terdiri atas sebuah lapisan kompak sel-sel besar, sel desidua, yang mengandung banyak sekali lipid dan glikogen. Lapisan ini lempeng desidua melekat erat dengan korion.

Lapisan desidua di kutub abembrional disebut desidua kapsularis. Dengan bertambah besarnya gelembung karion, lapisan ini menjadi teregang dan mengalami degenerasi. Selanjutnya, korion laeve bersentuhan dengan dinding rahim (desidua parietalis) pada rahim sisi yang lain dan keduanya menyatu, dan dengan demikian menutup rongga rahim. Oleh karena itu, satu-satunya bagian karion yang ikut serta dalam proses pertukaran adalah karion frondosum yang bersama dengan desidua basalis akan membentuk plasenta. Demikian pula, penyatuan amnion dan korion hingga membentuk membran amniokorion akan menutup rongga korion. Membran inilah yang pecah pada saat persalinan berlangsung (pecah ketuban).

Pada hari 8-9, perkembangan trofoblas sangat cepat, dari selapis sel tumbuh menjadi berlapis-lapis. Terbentuk rongga-rongga vakuola yang banyak pada lapisan sinsitiotrofoblas (selanjutnya disebut sinsitium) yang akhirnya saling berhubungan. Stadium ini disebut stadium berongga (lacunar stage).

Pertumbuhan sinsitium ke dalam stroma endometrium makin dalam kemudian terjadi perusakan endotel kapiler di sekitarnya sehingga rongga-rongga sinsitium (sistem lakuna) tersebut dialiri masuk oleh darah ibu, membentuk sinusoid-sinusoid. Peristiwa ini menjadi awal terbentuknya sistem sirkulasi uteroplasenta/sistem sirkulasi feto-maternal. Sementara itu, di antara lapisan dalam 
sitotrofoblas dengan selapis sel selaput Heuser, terbentuk sekelompok sel baru yang berasal dari trofoblas dan membentuk jaringan penyambung yang lembut, yang disebut mesoderm ekstraembrional.

Bagian yang berbatasan dengan sitotrofoblas disebut mesoderm ekstraembrional somatopleural, kemudian akan menjadi selaput korion (chorionic plate). Bagian yang berbatasan dengan selaput Heuser dan menutupi bakal yolk sac disebut mesoderm ekstrembrional splanknopleural. Menjelang akhir minggu kedua (hari 13-14), seluruh lingkaran blastokista telah terbenam dalam uterus dan diliputi pertumbuhan trofoblas yang telah dialiri darah ibu. Meski demikian, hanya sistem trofoblas di daerah dekat embrioblas saja yang berkembang lebih aktif dibandingkan daerah lainnya.

Pada lapisan mesoderm esktraembrional juga terbentuk celahcelah yang makin lama makin besar dan bersatu sehingga terjadilah rongga yang memisahkan kandung kuning telur makin jauh dari sitotrofoblas. Rongga ini disebut rongga selom ekstraembrional (extraembryonal coelomic space) atau rongga korion (chorionic space).

Di sisi embrioblas (kutub embrional), tampak sel-sel kuboid lapisan sitotrofoblas mengadakan invasi ke arah lapisan sinsitium, membentuk sekelompok sel yang dikelilingi sinsitium disebut jonjot-jonjot primer (primary stem villi). Jonjot ini memanjang sampai bertemu dengan aliran darah ibu. Pada awal minggu ketiga, mesoderm ekstraembrional somatopleural yang terdapat di bawah jonjot-jonjot primer (bagian dari selaput korion di daerah kutub embrional), ikut menginvasi ke dalam jonjot sehingga membentuk jonjot sekunder (secondary stem villi) yang terdiri atas inti mesoderm dilapisi selapis sel sitotrofoblas dan sinsitiotrofoblas. 
Menjelang akhir minggu ketiga, dengan karakteristik angiogenik yang dimilikinya, mesoderm dalam jonjot tersebut berdiferensiasi menjadi sel darah dan pembuluh kapiler sehingga jonjot yang tadinya hanya selular kemudian menjadi suatu jaringan vaskular (disebut jonjot tersier/tertiary stem villi).

Selom ekstraembrional/rongga korion makin lama makin luas sehingga jaringan embrional makin terpisah dari sitotrofoblas/selaput korion, hanya dihubungkan oleh sedikit jaringan mesoderm yang kemudian menjadi tangkai penghubung (connecting stalk). Mesoderm connecting stalk yang juga memiliki kemampuan angiogenik, kemudian akan berkembang menjadi pembuluh darah dan connecting stalk tersebut akan menjadi tali pusat.

Setelah infiltrasi pembuluh darah trofoblas ke dalam sirkulasi uterus, seiring dengan perkembangan trofoblas menjadi plasenta dewasa, terbentuklah komponen sirkulasi utero-plasenta. Melalui pembuluh darah tali pusat, sirkulasi utero-plasenta dihubungkan dengan sirkulasi janin. Meskipun demikian, darah ibu dan darah janin tetap tidak bercampur menjadi satu disebut sistem hemochorial, tetap berpisah oleh dinding pembuluh darah janin dan lapisan korion.

Dengan demikian, komponen sirkulasi dari ibu (maternal) berhubungan dengan komponen sirkulasi dari janin (fetal) melalui plasenta dan tali pusat, sistem tersebut dinamakan sirkulasi fetomaternal.

Pertumbuhan plasenta makin lama makin besar dan luas, umumnya mencapai pembentukan lengkap pada usia kehamilan sekitar 16 minggu.

Plasenta lengkap yang normal memiliki karakteristik berikut ini :

1. Bentuk bundar/oval.

2. Diameter $15-25 \mathrm{~cm}$, tebal $3-5 \mathrm{~cm}$.

3. Berat rata-rata 500-600 gram. 
4. Insersi tali pusat atau tempat yang berhubungan dengan plasenta dapat berada di tengah/sentralis, disamping/lateralis, atau di ujung tepi/marginalis.

5. Di sisi ibu, tampak daerah-daerah yang agak menonjol (kotiledon) yang diliputi selaput tipis desidua basalis.

6. Di sisi janin, tampak sejumlah arteri dan vena besar (pembuluh korion) menuju tali pusat. Korion diliputi oleh amnion.

7. Sirkulasi darah ibu di plasenta sekitar $300 \mathrm{cc} /$ menit (20 minggu) meningkat sampai 600-700 cc/menit (aterm).

Pada kehamilan multipel/kembar, dapat terjadi variasi jumlah dan ukuran plasenta, serta selaput janin.

\section{Fungsi Plasenta}

Fungsi plasenta adalah menjamin kehidupan dan pertumbuhan janin yang baik.

1. Nutrisi : memberikan bahan makanan pada janin.

2. Ekskresi : mengalirkan keluar sisa metabolisme janin.

3. Respirasi : memberikan $\mathrm{O} 2$ dan mengeluarkan $\mathrm{CO} 2$ janin.

4. Endokrin : menghasilkan hormon-hormon hCG, HPL, esterogen, progesteron, dan sebagainya.

5. Imunologi : menyalurkan berbagai komponen antibodi ke janin.

6. Farmakologi : menyalurkan obat-obatan yang mungkin diperlukan yang diberikan melalui ibu.

7. Proteksi : barier terhadap infeksi bakteri dan virus, zat-zat toksik (tetapi akhir-akhir ini diragukan, karena pada kenyataannya janin sangat mudah terpapar infeksi/intoksikasi yang dialami ibunya).

\section{Struktur Plasenta}

Plasenta berbentuk oval dengan diameter $15-20 \mathrm{~cm}$ dan berat 500-600 gram. Plasenta terbentuk lengkap saat usia kehamilan 16 
minggu, ketika ruang amnion telah mengisi seluruh rongga rahim. Plasenta terletak di dalam rahim. Bagian - bagian plasenta meliputi:

1. Bagian fetal : villi korialis, ruang intervili. Darah dari ibu di ruang intervili berasal dari arteri spiralis yang berada di desidua basalis. Pada sistol, darah dipompa dengan tekanan 70-80 $\mathrm{mmHg}$ ke ruang intervili sampai pada pangkal kotiloden, darah membanjiri ke vili korialis dan kembali secara perlahan melalui pembuluh balik (vena) dengan tekanan $8 \mathrm{mmHg}$.

2. Bagian permukaan janin : merupakan bagian permukaan janin, tepatnya di uri yang dilapisi oleh selaput amnion.

3. Bagian maternal : terdiri dari desidua kompakta yang terdiri dari beberapa lobus dan kotiledon (15-20 lobus). Pertukaran uteroplasenta terjadi melalui intervili tali pusat.

Menjelang permulaan bulan kedua, trofoblas ditandai oleh banyak sekali vili sekunder dan tersier yang memberinya bentuk radial. Vili ini berakar pada mesoderm lempeng korion dan di sebelah perifer melekat pada desidua ibu melalui kulit sitotrofoblas luar. Permukaan vili dibentuk oleh sinsitium, yang terletak di atas selapis sel sitotrofoblas, yang selanjutnya akan membungkus inti mesoderm vaskular. Sistem kapiler di dalam inti batang vili segera berhubungan dengan kapiler di dalam lempeng korion dan tangkai penghubung, dengan demikian tersusunlah susunan pembuluh darah ekstraembrional.

Pada bulan-bulan berikutnya, banyak tonjol-tonjol kecil tumbuh dari tangkai vili yang sudah ada menuju ke dalam ruang lakuna atau ruang intervili (antarvili) di sekitarnya. Vili yang baru terbentuk ini pada mulanya masih primitif, tetapi menjelang permulaan bulan keempat, sel-sel sitotrofoblas beserta sebagian sel jaringan ikat menghilang. Setelah itu hanya sinsitium dan dinding endotel pembuluh darah yang menjadi lapisan pemisah 
antara peredaran darah ibu dan janin. Kerapkali sinsitium menjadi sangat tipis dan potongan-potongan besar yang mengandung beberapa nuklei bisa menembus dan masuk ke dalam danaudanau darah di antara vili. Potongan-potongan yang dikenal sebagai gumpal-gumpal sinsitium ini memasuki peredaran darah ibu dan biasanya mengalami degenerasi tanpa menimbulkan gejala. Menghilangnya sel-sel sitotrofoblas berlangsung terus dari vili yang kecil ke vili yang lebih besar, sel-sel ini tidak ikut serta dalam pertukaran antara kedua peredaran darah tersebut.

Menjelang permulaan bulan keempat, plasenta mempunyai dua komponen : (a) bagian janin, yang dibentuk oleh korion frondosum; dan (b) bagian ibu yang dibentuk oleh desidua basalis. Pada sisi janin, plasenta dibatasi oleh lempeng korion; pada sisi ibu oleh desidua basalis, yang lempeng desidua-nya berhubungan paling erat ke plasenta. Pada daerah persambungan ini, sel-sel trofoblas dan desidua bercampur aduk. Zona ini ditandai dengan sel-sel raksasa desidua dan sinsitium, dan kaya akan bahan mukopolisakarida amorf. Pada saat ini, kebanyakan sel sitotrofoblas sudang berdegenerasi. Di antara lempeng korion dan lempeng desidua terdapat ruang intervili yang berisi darah ibu. Ruang-ruang ini terbentuk dari lakuna-lakuna di dalam sinsitiotrofoblas dan dilapisi oleh sinsitium yang berasal dari janin. Percabangan vili ini tumbuh ke dalam danau-danau darah intervili.

Selama bulan keempat dan kelima, desidua membentuk banyak sekat desidua, yang menonjol ke dalam ruang intervili tetapi tidak mencapai lempeng korion. Sekat-sekat ini mempunyai inti dari jaringan ibu, tetapi permukaannya dibungkus oleh lapisan sel sinsitium, sehingga selamanya terdapat selapis sinsitium yang memisahkan darah ibu di danau intervili dari jaringan janin pada vili tersebut. Sebagai akibat terbentuknya sekat-sekat ini, plasenta terbagi menjadi sejumlah ruangan atau kotiledon. Oleh karena 
sekat desidua tidak mencapai lempeng korion, hubungan antarruang vili di dalam berbagai kotiledon tetap terpelihara.

Sebagai akibat berlanjutnya pertumbuhan janin dan bertambah besarnya rahim, plasenta juga membesar. Penambahan luas permukaan secara kasar sebanding dengan pembesaran rahim, dan di sepanjang kehamilan, plasenta menutupi kira-kira 25 sampai 30 persen permukaan dalam rahim. Bertambah tebalnya plasenta disebakan oleh arborisasi vili yang sudah ada dan bukan karena penembusan lebih jauh ke dalam jaringan ibu.

\section{Peredaran Darah Plasenta}

Kotiledon menerima darah dari 80 sampai 100 aa. Spiralis yang menembus lempeng desidua dan memasuki ruang-ruang intervili dengan jarak yang cukup teratur.

Lumen arteri spiralis sempit, sehingga mengakibatkan tingginya tekanan darah sewaktu memasuki ruang intervili. Tekanan ini menyemburkan darah dalam-dalam ke ruang intervili dan membasahi banyak vili kecil dari percabangan vili dengan arah yang kaya oksigen. Pada waktu tekanan menurun, darah mengalir kembali dari lempeng korion ke desidua, dan memasuki vena endometrium. Karena itu, darah yang berasal dari danau-danau intervili mengalir kembali ke dalam peredaran darah ibu melalui vena endometrium.

Secara keseluruhan, ruang intervili pada plasenta telah tumbuh sempurna mengandung kira-kira $150 \mathrm{~mL}$ darah, yang diganti kirakira 3 atau 4 kali dalam semenit. Darah ini mengalir sepanjang vili korion, yang mempunyai luas permukaan berkisar dari 4 hingga 14 meter persegi. Akan tetapi, pertukaran di plasenta tidak 
berlangsung di semua vili, tetapi hanya pada vili yang pembuluh janinnya berhubungan erat dengan membran sinsitium yang membungkusnya. Pada vili ini, sinsitium kerap kali mempunyai brush border yang terdiri atas banyak vili halus, sehingga sangat menambah luas permukaan, dan akibatnya meningkatkan kecepatan pertukaran antara peredaran darah ibu dan janin.

Selaput plasenta memisahkan darah ibu dan janin dan mulamula terdiri atas empat lapisan : (a) lapisan endotel pembuluh darah janin, (b) jaringan ikat di dalam inti vili, (c) lapisan sitotrofoblas, dan (d) sinsitium. Akan tetapi sejak bulan keempat dan seterusnya, membran plasenta menjadi jauh lebih tipis, karena lapisan endotel pembuluh darah menjadi melekat erat pada selaput sinsitium, dengan banyak sekali meningkatkan kecepatan pertukaran. Meskipun kadangkala disebut sawar plasenta, membran plasenta bukanlah suatu sawar yang sebenarnya, karena banyak zat dapat melintasinya dengan bebas. Oleh karena darah ibu di dalam ruang intervili terpisah dari darah janin oleh sekat yang berasal dari korion, plasenta manusia dianggap dari jenis hemokorialis.

\section{Plasenta Cukup Bulan}

Pada saat cukup bulan, plasenta berbentuk seperti cakram, garis tengahnya 15 sampai $25 \mathrm{~cm}$, tebalnya kira-kira $3 \mathrm{~cm}$ dan beratnya kira-kira 500 sampai 600 gram. Saat persalinan, plasenta terlepas dari dinding rahim dan kira-kira 30 menit setelah bayi lahir, plasenta didorong keluar dari rongga rahim. Setelah dilahirkan, pada plasenta sisi ibu tampak dengan jelas 15-20 daerah yang agak menonjol yang disebut kotiledon, yang dilapisi oleh sebuah selaput tipis desidua basalis. Siklus-siklus di antara kotiledon dibentuk oleh sekat-sekat desidua. Banyak desidua untuk sementara tetap berada di dalam rahim dan dikeluarkan bersamasama dengan lokia (cairan nifas). 
Plasenta pada sisi janin seluruhnya dibungkus oleh lempeng korion, sejumlah pembuluh vena dan arteri besar, pembuluhpembuluh darah korion, terlihat menuju ke tali pusat. Korion selanjutnya akan dibungkus oleh amnion.

Tempat perlekatan tali pusat ke plasenta (insersi tali pusat) umumnya di tengah plasenta (insersio sentralis). Pada beberapa kasus insersi sedikit ke samping (insersio parasentralis), di samping (insersio lateralis), atau di pinggir/tepi (insersio marginalis). Jika tali pusat berinsersi di luar plasenta maka disebut insersio velamentosa. Kondisi ini dianggap tidak normal namun jarang sekali terjadi.

\section{Tali Pusat}

Mesoderm connecting stalk yang juga memiliki kemampuan angiogenik, kemudian akan berkembang menjadi pembuluh darah dan connecting stalk tersebut akan menjadi tali pusat. Pada tahap awal perkembangan, rongga perut masih terlalu kecil untuk usus yang berkembang sehingga sebagian usus terdesak ke dalam rongga selom ekstraembrional pada tali pusat. Pada sekitar akhir bulan ketiga, penonjolan lengkung usus (intestional loop) ini masuk kembali ke dalam rongga abdomen janin yang telah membesar.

Kandung kuning telur (yolk-sac) dan tangkai kandung kuning telur (ductus vitellinus) yang terletak dalam rongga karion, yang juga tercakup dalam connecting stalk juga tertutup bersamaan dengan proses semakin bersatunya amnion dengan karion. Setelah struktur lengkung usus, kandung kuning telur, dan ductus vitellinus menghilang, tali pusat akhirnya hanya mengandung pembuluh darah umbilikal ( 2 arteri umbilikus dan 1 vena umbilikalis) yang menghubungkan sirkulasi janin dengan plasenta. Pembuluh darah umbilikalis ini diliputi oleh mukopolisakarida yang disebut Wharton's jelly. 
Tali pusat janin rata-rata panjangnya $50-55 \mathrm{~cm}$ dengan diameter $1-2,5 \mathrm{~cm}$. Tali pusat terpanjang yang pernah ada adalah $200 \mathrm{~cm}$ dan yang terpendek $1 \mathrm{~cm}$. Struktur tali pusat terdiri dari 2 arteri umbilikalis yaitu 1 vena umbilikalis dan jeli warthon (zat seperti agar-agar, yang banyak mengandung air sehingga setelah bayi lahir tali pusat mudah menjadi kering dan lekas terlepas dari pusarnya). Dari luar, tali pusat tampak berwarna putih.

\section{Selaput Ketuban (Amnion dan Korion)}

Pada minggu-minggu pertama perkembangan, villi/jonjot meliputi seluruh lingkaran permukaan korion.

Dengan berlanjutnya kehamilan :

1. Jonjot pada kutub embrional membentuk struktur korion lebat seperti semak-semak (chorion frondosum) sementara.

2. Jonjot pada kutub abembrional mengalami degenerasi, menjadi tipis dan halus disebut chorion laeve.

Seluruh jaringan endometrium yang telah mengalami reaksi desidua, juga mencerminkan perbedaan pada kutub embrional dan abembrional.

1. Desidua di atas korion frondosum menjadi desidua basalis.

2. Desidua yang meliputi embrioblas/kantong janin di atas korion laeve menjadi desidua kapsularis.

3. Desidua di sisi/bagian uterus yang abembrional menjadi desidua parietalis.

Antara membran korion dengan membran amnion terdapat rongga korion. Dengan berlanjutnya kehamilan, rongga ini tertutup akibat persatuan membran amnion dan membran 
amnion. Selaput janin selanjutnya disebut sebagai membran karion-amnion (amniochorionic membrane). Kavum uteri juga terisi oleh konsepsi sehingga tertutup oleh persatuan chorion laeve dengan desidua parietalis.

\section{BAB 4 \\ KODE GENETIK}

\subsection{PRINSIP HUKUM MENDEL}

1. Hybrid (hasil persilangan dua individu dengan tanda beda) memiliki sifat yang mirip dengan individunya dan setiap hybrid mempunyai sifat yang sama dengan hybrid yang lain dari spesies yang sama.

2. Karakter (sifat) keturunan suatu hybrid selalu timbul kembali secara teratur dan inilah yang memberi petunjuk pada Mendel, bahwa ada faktor penentu yang mengambil peranan dalam pemindahan sifat dari satu generasi ke generasi berikutnya.

3. Bila faktor-faktor keturunan mengikuti distribusi yang logis, maka suatu hukum atau pola akan dapat diketahui dengan mengadakan banyak persilangan dan menghitung bentukbentuk yang berbeda seperti yang tampak dalam keturunan.

a. Prinsip pemisahan dan pemilihan gen (menurut Mendel) merupakan pengembangan dasar bagi ilmu genetika.

b. Mendel menyebutkan bahwa bahan genertik hanya faktor menentu (determinant). 
c. Banyak ilmuwan dan penemu dalam genetika selain Mendel, yaitu T.A. Knigh dan J.Goss; Morgan; W.Bateson dan E.R. Saunders.

\section{HUKUM MENDEL I}

Pemisahan Gen Se-Alel

"Segregation of Allelic Genes"

Peristiwa pemisahan alel ti 86 ketika pembuatan gamet (gametogenesis F1) individu yaır ınemiliki genotip heterozigot sehingga tiap gamet memiliki salah satu alel tersebut.

Contohnya :

Pada persilangan kacang karpi yang semula bergenotip TT (Inggris=tall) dan kacang kerdil bergenotip kerdil (tt). Hal ini mengadakan penyerbukan sendiri (alamiah) TTxtt, maka keturunannya memiliki rasio genotip tiga macam: $\mathrm{TT}, \mathrm{Tt}$, dan tt (1:2:1) dan rasio fenotip = tinggi : tinggi : rendah (3:1). Karakter $\mathrm{t}$ (rendah) ditutupi oleh karakter $\mathrm{T}$ (tinggi). Dalam hal ini, karakter tinggi dominan.

Keturunan pertama disebut $P$ (parental).

Keturunan $P$ disebut $F$ (filial), anak P disebut F1, cucu P disebut F2, yang berasal dari perkawinan antara F1 dengan F1.

Diagram persilangan :

$P \quad$ : TT $x$ tt

F1 : Tt

Gamet $\mathrm{Tt}$

F2 : F1 $\times$ F1

\begin{tabular}{c|c|c} 
& $\mathrm{T}$ & $\mathrm{t}$ \\
\hline $\mathrm{T}$ & $\mathrm{TT}$ & $\mathrm{Tt}$ \\
\hline $\mathrm{t}$ & $\mathrm{Tt}$ & $\mathrm{tt}$
\end{tabular}



Catatan :
$\mathrm{TT}=$ homozigot dominan
$\mathrm{Tt}=$ heterozigot
$\mathrm{Tt}=$ homozigot resesif

\section{HUKUM MENDEL II}

Pengelompokan Gen Secara Bebas

"Independen Assortment Of Genes"

Hukum ini berlaku ketika pembentukan gamet, di mana gen sealel secara bebas pergi ke masing-masing kutub ketika meiosis.

Ketika terjadi meiosis pada gametogonium individu yang memiliki genotip dobel-heterozigot, triple heterozigot, dan seterusnya sesuai dengan jenis hibridnya, apakah di-, tri-, atau poli-hibrid. Pada waktu anafase 1 pemisahan dan pengelompokkan gen terjadi secara bebas, apakah ke kutub atas bawah (bidang equator).

Pembuktian hukum ini dipakai pada hibrid dan polihibrid, yaitu persilangan dari individu yang memiliki dua atau lebih karakter. Hukum ini disebut juga hukum asotasi, misalnya ada dua pasang gen A-a dan B-b. Masing - masing gen itu kita bubuhkan pada kromosom berbeda, maka pada awal meiosis digambarkan ada dua pasang kromosom. Pada anafase meiosis 1 terjadi pemisahan dan perpindahan kromosom homolog ke masing-masing kutub, yaitu kutub atas dan kutub bawah. Satu pasang berlengan panjang (A-a), 1 pasang berlengan pendek (B-b).

Ada empat macam pengelompokkan kedua pasang gen yaitu sebagai berikut :

1. Kromosom A dan B ke kutub atas.

2. Kromosom a dan b ke kutub bawah. 
3. Kromosom $\mathrm{A}$ dan $\mathrm{b}$ ke kutub atas.

4. Kromosom a dan B ke kutub bawah.

Dengan demikian dihasilkan empat macam gamet yang terbentuk pada akhir meiosis: $A B, a b, A b, a B$.

Gamet $A B$ (singkatan dari gamet yang mengandung gen $A$ dan $B$ ) bersama gamet ab disebut memiliki kombinasi (pengelompokan asli) = KOMBINASI PARENTAL.

Gamet $A b$ dan $a B$ disebut memiliki kombinasi baru dikenal dengan REKOMBIAN.

Pada bagian inilah berlaku hukum Mendel II, yaitu ketika terjadinya meiosis pada gametagonium, individu yang memiliki genotip dobel heterozigot, dan seterusnya sesuai dengan jenis hibridnya, apakah : di, tri, atau poli-hidrid. Pada waktu ANAFASE I itu pemisahan dan pengelompokkan gen-gen itu terjadi secara bebas, apakah ke kutub atas atau ke kutub bawah.

Pada dihibrid :

$P=A A B B \times a a b b$

$\mathrm{F} 1=\mathrm{AaBb}$ (Double heterozygot), gamet pada $\mathrm{F} 1=\mathrm{AB}, \mathrm{Ab}, \mathrm{aB}, \mathrm{ab}$

Jika F1 disilang interse, maka pada F2 terdiri atas $4 \times 4$ kolom = 16 kolom. Berarti kotak perkawinan itu terdiri atas 16 kotak.

Pada trihibrid :

Jika $\mathrm{P}$ ialah $\mathrm{AABBCC} \times \mathrm{x}$ aabbcc, $\mathrm{F} 1=\mathrm{AaBbCc}$ (tripleheterozygot). Maka gamet $\mathrm{F} 1$ ada 8 jenis $=A B C, A b c, A b C, A b c, a B c, a b C, a b c$, jika F1 kawin interse berapakah jumlah kotak perkawinannya? $8 \mathrm{x}$ 8 ( 8 macam gamet jantan dan 8 macam gamet betina $=64$ buah). 
Contoh dihibrid pada manusia :

- Rambut keriting dan kidal

- Haemoglobin abnormal dan haemoglobinohtia

Rambut keriting dominan terhadap lurus. Kidal resesif terhadap normal (kegiatan tangan menggunakan tangan kanan). Jika lakilaki normal kawin dengan perempuan keriting kidal, carilah ratio fenotip anaknya.

$\mathrm{Kr}=$ keriting, $\mathrm{kr}=$ normal (lurus), $\mathrm{Kd}=$ normal, $\mathrm{kd}=$ kidal.

Dapat dikatakan laki-laki normal, normal genotipnya krkrKdKd. Perempuan keriting kidal bergenotipe mungkin Krkrkdkd atau Krkrkdkd. Karena suami memiliki dua macam kemungkinan genotipe dan istri juga kemungkinan memiliki 2 macam genotipe, maka kemungkinan kombinasi perkawinan ada 4 macam juga.

1. $k r k r K d K d x$ KrKrkdkd

2. $k r k r K d K d \times K r k r k d k d$

3. krkrKdkd $x$ KrKrkdkd

4. $k r k r K d K d x$ Krkrkdkd

Hemoglobin abnormal dan hemoglobinophatia. Sicklemia dan thalasemia termasuk golongan hemoglobinophatia, yaitu suatu penyakit genetik yang berhubungan dengan keabnormalan $\mathrm{Hb}$ (hemoglobin). Hemoglobin terbagi oleh hemed dan globin. Globin terdiri atas 4 rantai, pada setiap rantai melekat 1 molekul heme yang mengandung 1 atom $\mathrm{Fe}$. Ada $\mathrm{Hb}$ yang dibangun oleh 1 atau 2 jenis rantai.

$\mathrm{Hb}$ normal paling umum terdapat pada orang dewasa disebut $\mathrm{Hb}$ A, mengandung 2 rantai alpa dan 2 rantai beta. Angka 2 menunjukkan jumlah rantai dan huruf $A$ menunjukkan jenis $\mathrm{Hb}$. 
Dalam kadar rendah dalam tubuh orang normal terdapat $\mathrm{Hb} 2$ jenis yaitu $\mathrm{Hb} \mathrm{F}, \mathrm{Hb} \mathrm{A} 2$, dan $\mathrm{Hb}$ Gower.

$\mathrm{Hb} F$ membangun sebagian besar $\mathrm{Hb}$ embrio. Huruf $\mathrm{F}$ merupakan singkatan dari fetus (janin). Setelah bayi lahir, kadar $\mathrm{Hb} F$ turun, secara serentak kadar $\mathrm{Hb}$ A naik sehingga $\mathrm{Hb}$ A-lah yang membina sebagian besar hemoglobin darah (98\%), sedangkan kadar $\mathrm{Hb} \mathrm{F}$ tinggal $1 \%$.

$\mathrm{Hb}$ A2 terdapat sedikit bersama Hb F waktu dewasa. Hb Gower terdapat pada embrio umur sekitar 10 minggu. Hemoglobinophatia yang berasal dari keabnormalan $\mathrm{Hb}$ tersebut dapat disebabkan karena hal-hal berikut ini.

1. Keabnormalan struktur rantai globin.

2. Keabnormalan perimbangan kadar $\mathrm{Hb}$.

3. Gabungan oleh keadaan 1 dan 2.

Genotipe hemoglobinophatia, untuk jenis sicklemia atau thalasemia dapat dipakai simbol sederhana S-s dan Th-th.

\subsection{HEREDITAS MAMIRE}

Hereditas adalah peristiwa pewarisan sifat orang tua pada anaknya yang disebabkan oleh kromosom adalah pembawa faktor atau sifat keturunan yang diwariskan kepada keturunannya.

\section{Dasar Genetika}

DNA atau AND

1. Mengandung informasi genetik, terdapat dalam kromosom (sedikit dalam mitokondria, kloroplas pada tumbuhan). ARN dan protein terdapat dalam sitoplasma.

2. Susunan molekul DNA dalam semua sel yang berbeda-beda dari suatu organisme adalah sama. Susunan ARN dan protein bervariasi dari setiap tipe sel baik kuantitas maupun kualitasnya. 
3. Adanya kolerasi antara banyaknya ADN tiap sel dengan jumlah sel kromosom dalam tiap sel. Sel somatik organisme diploid mengandung dua kali jumlah DNA dibandingkan jumlah DNA yang terdapat dalam gamet haploid.

\section{Struktur DNA}

Asam nukleat tersusun atas nukleotida (gula, pospat, basa nitrogen) polinukleotida. Banyaknya nukliotida penyusun DNA = polinukliotida yang tersusun dari hal-hal berikut ini :

1. Gula : deosiribosa.

2. Pospat: PO4.

3. Basa nitrogen :

a. Kelompok pirimidin : basa sitosin (S) kelompok pirimidin : basa sitosin ( $\mathrm{S}$ ) dan timin (T);

b. Kelompok purin : basa adenin (A) dan guanin $(G)$.

Pada tahun 1953 Watson dan Crick mengemukan bahwa molekul DNA mempunyai bentuk pita spiral double yang saling berpilin (model double helix).

\section{Model Double Helix DNA (Watson Crick)}

Deretan gula deoksiribosa dan pospat menyusun pita spiral dan merupakan punggung (back bone). Basa nitrogen berhubungan dengan gula. Satu spiral (360) mengandung 10 basa nitrogen. Jarak antara satu basa dengan basa lainnya 3,4 A (1 A = 0,0001 mikron). Sebuah pita spiral dalam double helix membuat satu spiral penuh setiap $34 \mathrm{~A}$. Lebar molekul DNA sepanjang double helix tetap, yaitu $20 \mathrm{~A}$.

Pada deretan nukleotida, pospat terletak di antara dua molekul gula sedemikian rupa sehingga pospat tersebut terikat pada $3 \mathrm{C}$ dari satu molekul gula dan pada $5 \mathrm{C}$ dari molekul gula berikutnya. Struktur double helix dapat stabil, jika basa adenin dari satu pita 
berpasangan dengan basa timin dari pita pasangannya. Demikian juga basa sintosis dengan guanin. Adenin dan timin dihubungkan dengan dua atom $\mathrm{H}$, sedangkan pasangan sitosis dan guanin oleh 3 atau H. Menurut Chargaff (1955) : banyaknya $A=T$ dan $S=G$.

\section{Replikasi DNA}

DNA terdapat dalam kromosom dan kromosom terdapat dalam inti sel. Sel membelah yang didahului oleh pembelahan inti sel. Kromosom membelah demikian juga DNA. Hipotesis cara replikasi DNA adalah sebagai berikut :
1. Semikonservatif.
2. Konservatif.
3. Dispersif.

\section{Struktur ARN (RNA)}

Molekul ARN lebih pendek dibandingkan DNA, ARN berbentuk pita tunggal (Single strand) tidak berpilin. Struktur ARN merupakan polimer nukleotida, perbedaannya adalah sebagai berikut :

1. Gula penyusunannya ribose.

2. Basa pirimidin penyusunnya bukan Timin tetapi Urasil (U).

Lokasi ARN tergantung pada jenisnya, yaitu sebagai berikutnya:

1. ARN Duta (ARNd), messenger RNA (mRNA) terdapat dalam nukleus. ARNd dicetak oleh salah satu pita DNA yang berlangsung dalam nukleus.

Jika urutan basa dalam pita DNA yang mencetak adalah 5 ... GTSAT ...3

2. ARN pemindah (ARNp), transfer RNA (tRNA), terdapat dalam sitoplasma.

3. ARN ribosom. 
Molekul ARNp terdapat dalam sitoplasma, pada beberapa bagian, basa - basanya memperlihatkan pasangan, tetapi tidak membentuk dobel heliks.

Fungsi ARN tergantung pada macamnya, yaitu sebagai berikut:

1. ARNd bertugas menerima informasi/keterangan genetik dari ADN. Proses ini disebut transkripsi dan berlangsung dalam inti sel.

2. ARNp bertugas mengikat asam amino yang terdapat dalam sitoplasma. Sebelum diikat oleh ARNp ke ribosom, asam amino bereaksi terlebih dahulu dengan ATP (Adenin Tripospat) agar berenergi. Di sinilah berlangsung perubahan informasi genetik yang dinyatakan oleh urutan basa dari ARNd ke urutan asam amino dalam protein yang dibentuk. Proses perubahan ini dinamakan translasi.

ARN ribosom (ARNr), bertugas menyintesis protein dengan menggunakan bahan asam amino. Proses ini berlangsung di dalam ribosom dan hasil akhirnya berupa polipeptida.

\section{Kode Genetik dan Sintesis Protein}

DNA mengandung informasi untuk mengatur dan membangun tubuh manusia. Protein diperlukan dalam semua proses dalam sel (baik protein struktural maupun protein fungsional). Protein struktural terdapat dalam membran, serabut kontraktil dan filamen intraselular, sedangkan protein fungsional seperti enzim, dibutuhkan sebagai katalisator pada sintesis persenyawaan kimia dalam tubuh. Sintesis protein berlangsung dalam ribosom dan sitoplasma. Perubahan pada sebuah basa tunggal menghasilkan sebuah triplet yang mengode berakhirnya suatu rantau polipeptida. Suatu mutasi gen dapat meliputi lebih dari sebuah basa dalam larutan molekul ADN. 
Gen-gen kontrol adalah sebuah gen yang dapat mengubah pengaruh dari gen lainnya (gen kontrol = gen regulator dan gen operator). Gen ini tidak berhubungan langsung dengan sintesis protein tertentu, tetapi mengatur aktivitas gen-gen struktural dan mengawasi banyaknya hasil gen.

\section{Penentuan Jenis kelamin}

Perbedaan seks pada makhluk hidup dipengaruhi oleh dua faktor, yaitu sebagai berikut :

1. Faktor lingkungan : dipengaruhi oleh faktor fisiologis. Sebagai contoh bila kadar hormon kelamin dalam tubuh tidak seimbang produk dan distribusinya, maka pernyataan fenotip kelaminnya dapat berubah.

2. Faktor genetik : ditentukan oleh komposisi dan kromosom karena bahan genetik terdapat dalam kromosom.

Berbagai tipe penentuan jenis kelamin adalah tipe $X Y$, tipe $X O$, tipe ZW, tipe ZO, dan tipe Ploidi.

\section{Tipe XY pada manusia}

Kromosom manusia dibedakan menjadi sebagai berikut :

1. Autosom (kromosom tubuh).

2. Gonosom (kromosom seks/kelamin).

Sel tubuh manusia mengandung 46 kromosom yang terdiri atas 44 (22 pasang) autosom dan 2 (1 pasang) kromosom seks/kelamin. Pada perempuan, kromosom kelamin berupa dua buah kromosom $X$ (XX) sehingga disebut homogametik, sedangkan pada pria, kromosom kelamin berupa sebuah kromosom $X$ dan sebuah kromosom $\mathrm{Y}$, disebut heterogametik. Formula kromosom untuk manusia adalah sebagai berikut : 
1. Wanita : 22AAXX (cara lama) atau 46XX (cara baru).

2. Pria : 22AAXY (cara lama) atau 46XY (cara baru).

\section{Perbandingan Seks pada Manusia}

Secara teoritis kemungkinan lahirnya anak perempuan dan lakilaki mengikuti perbandingan seks 1 perempuan : 1 laki-laki. Akan tetapi jika kita melihat kenyataannya di berbagai daerah, tampak bahwa salah satu seks sering kali melebihi jumlahnya dibandingkan dengan seks yang lain. Beberapa argumen dapat menjelaskan fenomena ini. Argumen tersebut adalah sebagai berikut :

1. Migrasi.

2. Kecepatan sperma.

3. Diameter sperma.

4. Kelompok umur.

\section{Rangkai Jenis Kelamin}

Setiap individu mempunyai dua macam kromosom karena individu jantan dan betina mempunyai autosom yang sama, maka sifat dan keturunan yang ditentukan oleh gen pada autosom diwariskan dari orang tua kepada anak-anaknya.

Selain gen autosom dikenal juga gen yang terdapat dalam kromosom seks. Peristiwa ini dikenal dengan rangkai kelamin (seks linked genes).

Untuk itu dapat dibedakan sebagai berikut :

1. Gen terangkai $X$ ( $X$ linked gene) yaitu gen yang terangkai pada kromosom X.

2. Gen terangkai $Y(Y$ linked gene) yaitu gen yang terangkai pada kromosom $\mathrm{Y}$. 


\section{Perbedaan antara DNA dan RNA}

Berdasarkan penjelasan sebelumnya dapat disimpulkan beberapa perbedaan antara DNA dan RNA sebagai berikut :

1. Komponen

a. Gula pada DNA : deoksiribosa

b. Gula pada RNA : ribosa

c. Basa nitrogen :

- Purin

1) DNA adalah adenin dan guanin

2) RNA adalah adenin dan guanin

- Pirimidin

1) DNA adalah Timin dan Sitosin

2) RNA adalah Urasil dan Sitosin

2. Bentuk

a. DNA berbentuk rantai panjang, ganda dan berpilin (double heliks).

b. RNA berbentuk rantai pendek, tunggal dan tidak berpilin.

3. Letak

a. DNA terletak di dalam nukleus, kloroplas, mitokondria.

b. RNA terletak di dalam nukleus, sitoplasma, kloroplas, mitokondria.

4. Kadar

a. DNA : tetap (tidak dipengaruhi oleh aktivitas penyusun protein).

b. RNA : tidak tetap (dipengaruhi oleh aktivitas penyusun protein).

5. Fungsi

a. DNA lebih cenderung ke info genetik.

b. RNA lebih cenderung ke sintesis protein. 


\section{BAB 5 \\ FISIOLOGI KEHAMILAN, PERSALINAN DAN NIFAS}

\subsection{FISIOLOGI KEHAMILAN}

Kehamilan merupakan proses yang alamiah. Perubahanperubahan yang terjadi pada wanita selama kehamilan normal adalah bersifat fisiologis bukan patologis. Kehamilan juga merupakan proses alamiah untuk menjaga kelangsungan peradaban manusia. Kehamilan baru bisa terjadi jika seorang wanita sudah mengalami pubertas yang ditandai dengan terjadinya menstruasi. Banyak hal dan banyak organ yang terlibat selama proses kehamilan.

Organ reproduksi wanita dan payudara merupakan organ yang paling berfungsi selama proses kehamilan. Organ reproduksi wanita yang biasa disebut traktus genitalis terletak dalam rongga panggul, terbagi atas organ genetalia eksterna dan interna.

Genetalia eksterna adalah organ reproduksi wanita yang dapat dilihat dari luar bila wanita dalam posisi litotomi, fungsinya adalah untuk kopulasi. Sementara itu, genetalia interna adalah organ reproduksi wanita yang tidak dapat dilihat dari luar, terletak di sebelah dalam dan hanya dapat dilihat dengan alat khusus atau dengan pembedahan. Mengenai pembahasan kedua organ tersebut, dapat dilihat di bab 1.

Payudara (mammae) sebagai organ untuk proses laktasi yang mengalami banyak perubahan sebagai persiapan setelah janin lahir. Beberapa perubahan yang dapat diamati adalah sebagai berikut :

1. Selama kehamilan payı 98 bertambah besar, tegang dan berat. 
2. Dapat teraba nodul-nodul, akibat hipertrofi kelenjar alveoli.

3. Bayangan vena-vena lebih membiru.

4. Hiperpigmentasi pada areola dan puting susu.

5. Kalau diperas akan keluar air susu (kolostrum) berwarna kuning.

Perubahan fisiologis yang terjadi pada payudara selama kehamilan salah satunya terjadi hipervaskularisasi pembuluh darah akibat peningkatan hormon estrogen dan progesteron. Selain itu, juga terjadi peningkatan-peningkatan hormon somatomamotropin untuk produksi ASI sehingga menjadi lebih besar.

Perkembangan payudara ini terjadi karena pengaruh hormon saat kehamilan, yaitu estrogen, progesteron, dan somatomamotropin.

1. Fungsi hormon yang mempersiapkan payudara untuk pemberian ASI, antara lain sebagai berikut :

\section{a. Estrogen}

- Menimbulkan hipertrofi sistem saluran payudara.

- Menimbulkan penimbunan lemak dan air, serta garam sehingga payudara tampak makin besar.

- Tekanan serat saraf akibat penimbunan lemak, air, dan garam menyebabkan rasa sakit pada payudara.

\section{b. Progesteron}

- Mempersiapkan asinus sehingga dapat berfungsi.

- Menambah sel asinus.

\section{c. Somamotropin}

- Mempengaruhi sel asinus untuk membuat kasein, laktalbumin, dan laktoglobulin.

- Penimbunan lemak sekitar alveolus payudara.

2. Perubahan payudara pada ibu hamil.

a. Payudara menjadi lebih besar.

b. Areola payudara makin hitam karena hiperpigmentasi. 
c. Glandula montgomery makin tampak menonjol di permukaan areola mamae.

d. Pada kehamilan 12 minggu ke atas dari puting susu akan keluar cairan putih jernih (kolostrum) yang berasal dari kelenjar asinus yang mulai bereaksi.

e. Pengeluaran ASI belum terjadi karena prolaktin ini ditekan oleh Prolactine Inhibiting Hormone (PIH).

f. Setelah persalinan, dengan dilahirkannya plasenta, maka pengaruh estrogen, progesteron, dan somamotropin terhadap hipotalamus hilang sehingga prolaktin dapat dikeluarkan dan laktasi terjadi.

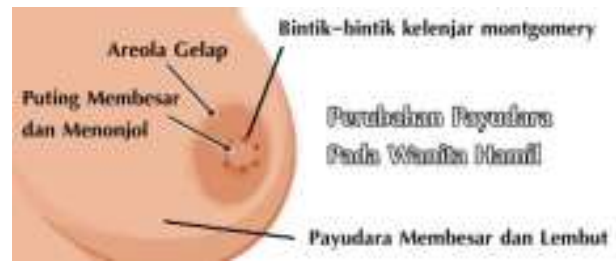

GAMBAR 5-1 Perubahan payudara pada wanita hamil

\subsection{FISIOLOGI PERSALINAN}

\section{Definisi Fisiologi Persalinan}

Persalinan adalah suatu proses pengeluaran hasil konsepsi yang dapat hidup dari dalam uterus ke dunia luar. Persalinan dan kelahiran normal adalah proses pengeluaran janin yang terjadi pada kehamilan cukup bulan (37-42 minggu), lahir spontan dengan presentasi belakang kepala yang berlangsung selama 18 jam, tanpa komplikasi baik pada ibu maupun pada janin.

Partus normal atau partus biasa merupakan proses kelah 
Fisiologi persalinan normal melibatkan dua hal dibawah ini :

1. Endokrinologi persalinan.

2. Fase-fase persalinan pada uterus.

Beberapa fase persalinan pada uterus adalah sebagai berikut :

1. Fase 0 : Fase tenang

a. Relaksasi otot miometrium.

b. Fase tenang yang normal ini terjadi pada $95 \%$ kehamilan.

c. Serviks rigid berkontraksi/kokoh.

d. Kadang-kadang terjadi kontraksi Barxton -hicks.

e. Pada fase ini, uterus refrakter terhadap induksi uterotonim.

\section{Fase 1 : Persiapan persalinan}

a. Ketenangan miometrium harus dihentikan.

b. Terjadi aktivasi uterus.

c. Perubahan progresif uterus 6-8 minggu terakhir.

d. Terjadi perubahan serviks, serviks menjadi lunak dan berdilatasi.

e. Fundus uteri memproduksi kontraksi.

f. Peningkatan yang menyolok reseptor oksitosin pada miometrium.

g. Peningkatan jembatan antar sel (gap junction) baik jumlah maupun area.

h. Iritabilitas uterus meningkat.

i. Responsif terhadap uterotonika.

j. Transisi waktu antara kontraksi his yang adekuat.

k. Pembentukan segmen bawah uterus.

I. Sebelum memasuki fase 2 , terjadi peningkatan $>50$ kali lipat jumlah reseptor oksitosin pada miometrium.

m. Pada serviks, terjadi pematangan serviks yang berkaitan dengan dua perubahan. 
n. Perusakan dan penyusunan kolagen, serta perubahan dalam jumlah relatif glikosaminoglikan, yaitu peningkatan asam hialuronat yang bersifat menahan air.

\section{Fase 2 : Proses persalinan}

a. Sinonim dengan kondisi in partu.

b. Kontraksi uterus membuat dilatasi serviks.

c. Pengeluaran janin dan plasenta.

\section{Fase 3 : Puerpurium}

a. Masa puerpurium.

b. Pemulihan ibu dari masa melahirkan anak.

c. Kontribusi ibu untuk kesejahteraan dan kelangsungan hidup anak.

d. Pemulihan fertilitas ibu.

e. Miometrium berada dalam keadaan rigid dan berkontraksi terus-menerus sehingga menekan pembuluh darah uterina.

f. Mencegah perdarahan postpartum.

g. Onset laktogenensis dan milk let down sangat penting bagi kelangsungan hidup bayi.

h. Involusi uterus 4-6 minggu (kembalinya uterus ke bentuk normal lagi).

\section{Sebab Terjadinya Proses Persalinan}

Penyebab pasti mulainya persalinan belum diketahui secara pasti, yang ada hanyalah teori-teori. Adapun teori-teori penyebab persalinan adalah sebagai berikut :

\section{Teori Keregangan}

a. Otot rahim mempunyai kemampuan meregang dalam batas tertentu.

b. Setelah melewati batas tersebut, maka akan terjadi kontraksi sehingga persalinan dapat dimulai. 


\section{Teori Penurunan Progesteron}

a. Proses penuaan plasenta terjadi mulai umur 28 minggu, di mana terjadi penimbunan jaringan ikat sehingga pembuluh darah mengalami penyempitan dan buntu.

b. Produksi progesteron mengalami penurunan sehingga otot rahim lebih sensitif terhadap oksitosin.

c. Akibatnya, otot rahim mulai berkontraksi setelah tercapai tingkat penurunan progesteron tertentu.

\section{Teori Oksitosin Internal}

a. Oksitosin dikeluarkan oleh kelenjar hipofisis pars posterior.

b. Perubahan keseimbangan estrogen dan progesteron dapat mengubah sensitivitas otot rahim sehingga terjadi kontraksi Braxton Hicks.

c. Menurunnya konsentrasi progesteron akibat tuanya usia kehamilan menyebabkan oksitosin meningkatkan aktivitas sehingga persalinan dimulai.

\section{Teori Prostaglandin}

a. Konsentrasi prostaglandin meningkat sejak usia kehamilan 15 minggu, yang dikeluarkan oleh desidua.

b. Pemberian prostaglandin saat hamil dapat menimbulkan kontraksi otot rahim sehingga hasil konsepsi dapat dikeluarkan.

c. Prostaglandin dianggap sebagai pemicu terjadinya persalinan

\section{Persalinan Normal}

Persalinan adalah suatu proses yang dimulai dengan adanya kontraksi uterus yang menyebabkan terjadinya dilatasi progresif dari serviks, kelahiran bayi, dan kelahiran plasenta, dimana proses tersebut merupakan proses alamiah. 
Persalinan adalah suatu proses pengeluaran hasil konsepsi dari rahim ibu melalui jalan lahir atau dengan jalan lain, yang kemudian janin dapat hidup ke dunia luar.

Persalinan dimulai (inpartu) sejak uterus berkontraksi sehingga menyebabkan perubahan pada serviks (membuka dan menipis) dan berakhir dengan lahirnya plasenta secara lengkap.

Partus normal/partus biasa merupakan proses bayi lahir melalui vagina dengan letak belakang kepala/ubun -ubun kecil, tanpa memakai alat/pertolongan istimewa, tidak melukai ibu maupun janin (kecuali episiotomi), serta berlangsung dalam waktu kurang dari 24 jam.

Jenis partus normal disebut juga persalinan spontan yang menggunakan kekuatan ibu secara alami. Selain itu, juga terdapat persalinan anjuran yang menggunakan rangsangan terlebih dahulu tetapi selanjutnya tetap menggunakan kekuatan ibu untuk proses persalinan selanjutnya.

\section{Beberapa faktor pendukung persalinan adalah sebagai berikut:}

\section{Power}

His (kontraksi ritmis otot polos uterus), kekuatan mengejan ibu, dan keadaan kardiovaskular respirasi metabolik ibu. Kekuatan ibu atau tenaga mengedan sangat mempengaruhi.

\section{Passage}

Keadaan jalan lahir yang terdiri atas panggul di mana terdiri atas beberapa posisi yaitu posisi Atas Panggul (PAP), posisi Pintu Tengah Panggul (PTP), dan posisi Pintu Bawah Panggul (PBP). Hal inilah yang mempengaruhi proses persalinan lancar atau tidaknya.

\section{Passenger}

Bagian dari penumpang atau yang akan dikeluarkan nantinya baik dari keadaan janin (letak, presentasi, ukuran/berat janin, ada/tidak kelainan anatomik mayor), keadaan plasenta yang 
normal atau abnormal, serta keadaan cairan amnion (ketuban) yang baik dalam proses persalinan.

\section{Psikis}

Keadaan kejiwaan ibu yang bisa mempengaruhi persalinan secara normal atau abnormal. Bila jiwa dan kondisi ibu baik, maka persalinan akan berjalan normal dan baik, sebaliknya bila keadaan jiwa dan kondisi ibu kurang baik, maka proses persalinan akan terhambat.

\section{Penolong}

Seseorang yang berfungsi sebagai penolong yaitu tenaga kesehatan, seperti bidan, perawat, dokter, dan dukun, di mana tenaga kesehatan tersebut mampu memberikan perlindungan, pengawasan, dan pelayanan dalam proses persalinan maupun setelah persalinan selesai.

\section{TANDA PERSALINAN}

Tanda dan gejala in partu adalah sebagai berikut :

1. Penipisan dan pembukaan serviks (effacement dan dilatasi serviks).

Effacement serviks adalah pemendekan dan penipisan serviks selama tahap pertama persalinan. Serviks dalam keadaan normal memiliki panjang 2 sampai $3 \mathrm{~cm}$ dan tebal sekitar $1 \mathrm{~cm}$, terangkat ke atas karena terjadi pemendekan gabungan otot uterus selama penipisan segmen bawah rahim pada tahap akhir persalinan.

Hal ini menyebabkan bagian ujung serviks yang tipis saja yang dapat diraba. Dilatasi serviks lengkap menandai akhir tahap pertama persalinan.

2. Kontraksi uterus yang mengakibatkan perubahan pada serviks (frekuensi minimal $\mathbf{2}$ kali dalam $\mathbf{1 0}$ menit).

Ibu melakukan kontraksi involunter dan volunter secara bersamaan untuk mengeluarkan janin dan plasenta dari uterus. 
Kontraksi uterus involunter, yang disebut kekuatan primer, menandai dimulainya persalinan. Kekuatan primer membuat serviks menipis, berdilatasi, dan janin turun.

Segera setelah bagian presentasi mencapai dasar panggul, sifat kontraksi berubah, yakni bersifat mendorong keluar. Kekuatan sekunder tidak mempengaruhi dilatasi serviks, tetapi setelah dilatasi serviks lengkap kekuatan ini cukup penting untuk mendorong bayi keluar dari uterus dan vagina.

\section{Keluarnya lendir bercampur darah (show) melalui vagina.}

Sumbatan mukus yang dibuat oleh sekresi servikal dari proliferasi kelenjar mukosa servikal pada awal kehamilan berperan sebagai barier protektif dan menutup kanal servikal pada awal kehamilan.

Blood show adalah pengeluaran dari mukus plug tersebut. Blood show merupakan tanda dari persalinan yang sudah dekat, yang biasanya terjadi dalam jangka waktu 24-48 jam terakhir, asalkan belum dilakukan pemeriksaan vaginal dalam 48 jam sebelumnya karena pemecahan mukus darah selama waktu tersebut mungkin hanya efek trauma minor atau pecahnya mukus plug selama pemeriksaan. Normalnya, darah yang keluar hanya beberapa tetes, perdarahan yang lebih banyak menunjukkan penyebab yang abnormal.

\section{Pengertian His}

His adalah gelombang kontraksi ritmis otot polos dinding uterus yang dimulai dari daerah fundus uteri di mana tuba fallopi memasuki dinding uterus, awal gelombang tersebut didapat dari pacemaker yang terdapat di dinding uterus daerah tersebut.

Resultan efek gaya kontraksi tersebut dalam keadaan normal mengarah ke daerah lokus minoris yaitu kanalis servikalis (jalan lahir) yang membuka untuk mendorong isi uterus keluar.

Penyebab terjadinya his adalah sebagai berikut :

1. Kerja hormon oksitosin. 
2. Regangan dinding uterus oleh isi konsepsi.

3. Rangsangan terhadap pleksus saraf Frankenhauser yang tertekan massa konsepsi.

His merupakan kontraksi miometrium yang bersifat fisiologik dan nyeri. Rasa nyeri karena his disebabkan oleh hal-hal berikut ini :

1. Hipoksia saat miometrium kontraksi.

2. Ganglion pada serviks dan SBR.

3. Regangan serviks uteri selama pembukaan.

4. Regangan pada peritoneum.

\section{His yang baik dan ideal meliputi hal-hal berikut ini :}

1. Kontraksi simultan simetris di seluruh uterus.

2. Kekuatan terbesar (dominasi) di daerah fundus.

3. Terdapat periode relaksasi di antara dua periode kontraksi.

4. Terdapat retraksi otot-otot korpus uteri setiap sesudah his.

5. Serviks uteri yang banyak mengandung kolagen dan kurang mengandung serabut otot akan tertarik ke atas oleh retraksi otot-otot korpus, kemudian terbuka secara pasif dan mendaftar (cervical effacement). Ostium uteri eksternum dan internum pun akan terbuka.

Nyeri persalinan pada waktu his dipengaruhi oleh berbagai faktor, sebagai berikut :

1. Iskemia dinding korpus uteri yang menjadi stimulasi serabut saraf di pleksus hipogastrikus diteruskan ke sistem daraf pusat menjadi sensasi nyeri.

2. Peregangan vagina, jaringan lunak dalam rongga panggul dan peritoneum, menjadi rangsang nyeri.

3. Keadaan mental pasien (pasien bersalin sering ketakutan, cemas/ansietas, atau eksitasi).

4. Prostaglandin meningkat sebagai respon terhadap stres. 


\section{Mekanisme Persalinan Normal}

Mekanisme persalinan normal adalah proses pengeluaran bayi dengan mengandalkan posisi, bentuk panggul, serta presentasi jalan lahir. Bagian terendah dari fetus akan menyesuaikan diri terhadap panggul pada saat turun melalui jalan lahir. Kepala akan melewati rongga panggul dengan ukuran yang menyesuaikan dengan ukuran panggul.

Gerakan - gerakan utama dari mekanisme persalinan adalah sebagai berikut :

1. Penurunan kepala.

2. Fleksi kepala.

3. Putar paksi dalam (PPD).

4. Ekstensi atau defleksi kepala.

5. Putaran paksi luar (PPL).

6. Ekspulsi.

\section{Penurunan Kepala}

Pada primigravida masuknya kepala ke dalam pintu atas panggul biasanya sudah terjadi pada bulan terakhir dari kehamilan, tetapi pada multigravida biasanya baru terjadi pada permulaan persalinan.

Masuknya kepala ke dalam pintu atas panggul biasanya dengan sutura sagitalis melintang dan dengan fleksi yang ringan. Masuknya kepala melewati pintu atas panggul dapat dalam keadaan sinklitismus yaitu bila sutura sagitalis terdapat di tengahtengah jalan lahir, tepat di antara simfisis dan promontorium.

Pada sinklitismus os pariental depan dan belakang sama tingginya. Jika sutura sagitalis agak ke depan mendekati simfisis atau agak ke 
belakang mendekati promontorium, maka dikatakan kepala dalam keadaan asinklitismus. Ada dua jenis asinklitismus yaitu sebagai berikut :

1. Asinklitismus posterior : bila sutura sagitalis mendekati simfisis dan os pariental belakang lebih rendah dari os pariental depan.

2. Asinklitismus anterior : bila sutura sagitalis mendekati promontorium sehingga os pariental depan lebih rendah dari os pariental belakang.

Derajat sedang asinklitismus pasti terjadi pada persalinan normal, tetapi jika berat gerakan ini dapat menimbulkan disproporsi sefalopelvik dengan panggul yang berukuran normal sekalipun.

Penurunan kepala lebih lanjut terjadi pada kala I dan kala II persalinan. Hal ini disebabkan karena adanya kontraksi dan retraksi dari segmen atas rahim yang menyebabkan tekanan langsung fundus pada bokong janin. Dalam waktu yang bersamaan terjadi relaksasi dari segmen bawah rahim sehingga terjadi penipisan dan dilatasi serviks. Keadaan ini juga menyebabkan bayi terdorong ke dalam jalan lahir. Turunnya kepala ke dalam panggul disebabkan oleh hal-hal sebagai berikut :

1. Tekanan air ketuban.

2. Tekanan langsung fundus uteri pada bokong.

3. Kekuatan mengejan.

4. Melurusnya badan fetus. 


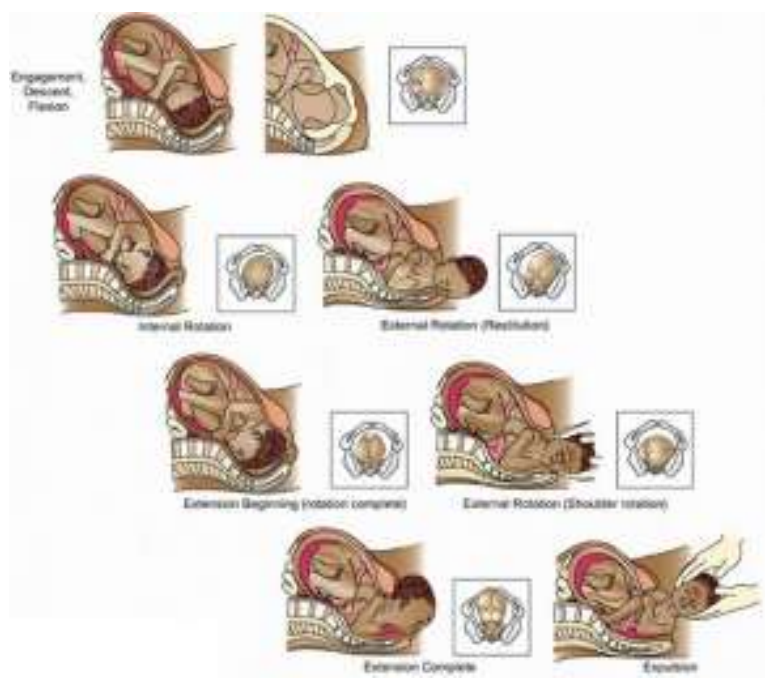

GAMBAR 5-2 Mekanisme persalinan

\section{Fleksi Kepala}

Pada awal persalinan, kepala bayi dalam keadaan fleksi yang ringan. Dengan majunya kepala biasanya fleksi juga bertambah. Pada pergerakan ini dagu dibawa lebih dekat ke arah dada janin sehingga Ubun-Ubun kecil lebih rendah dari Ubun-ubun besar. Hal ini disebabkan karena adanya tahanan dari dinding serviks, dinding pelvis, dan lantai pelvis. Dengan adanya fleksi, diameter suboccipito bregmatika 9,5 cm menggantikan diameter suboccipito frontalis $11 \mathrm{~cm}$. Sampai di dasar panggul biasanya kepala janin berada dalam keadaan fleksi maksimal.

Ada beberapa teori yang menjelaskan mengapa fleksi dapat terjadi, hal ini disebabkan karena janin didorong maju dan sebaliknya mendapat tahanan dari serviks, dinding panggul atau dasar panggul. Akibat dari keadaan ini terjadilah fleksi.

Terjadinya fleksi kepala karena kepala mendapat tahanan dari serviks uteri, dinding panggul dan dasar panggul. 


\section{Putaran Paksi Dalam}

Putaran paksi dalam adalah pemutaran dari bagian depan sedemikian rupa sehingga bagian terendah dari bagian depan janin memutar ke depan ke bawah simfisis. Pada presentasi belakang kepala bagian yang terendah adalah daerah ubun-ubun kecil dan bagian inilah yang akan memutar ke depan ke arah simfisis.

Rotasi dalam penting untuk menyelesaikan persalinan, karena rotasi dalam merupakan suatu usaha untuk menyesuaikan posisi kepala dengan bentuk jalan lahir khususnya bidang tengah dan pintu bawah panggul.

1. Pemutaran bagian terbawah dari bagian depan fetus ke depan ke arah simfisis pubis, meskipun jarang ke belakang ke arah sakrum.

2. Suatu usaha menyesuaikan diri dari posisi kepala dengan bentuk jalan lahir khususnya pintu atas panggul dan pintu bawah panggul.

\section{Ekstensi Kepala}

Sesudah kepala janin sampai di dasar panggul dan ubun-ubun kecil berada di bawah simfisis, maka terjadilah ekstensi dari kepala janin. Hal ini disebabkan karena sumbu jalan lahir pada pintu bawah panggul mengarah ke depan dan ke atas sehingga kepala harus mengadakan fleksi untuk melewatinya. Jika kepala yang berada dalam keadaan fleksi penuh pada waktu mencapai dasar panggul tidak melakukan ekstensi, maka kepala akan tertekan pada perineum dan dapat menembusnya.

Suboksiput yang tertahan pada pinggir bawah simfisis akan menjadi pusat pemutaran (hypomochlion) maka lahirlah bertururturut pada pinggir atas perineum : ubun-ubun besar, hidung, mulut, dan dagu bayi dengan gerakan ekstensi. Pada dasar 
panggul kepala mengadakan ekstensi/defleksi supaya kepala dapat melalui pintu bawah panggul.

Ekstensi kepala terjadi sebagai resultan antara dua kekuatan yaitu sebagai berikut :

1. Kekuatan uterus yang mendesak kepala lebih ke arah belakang.

2. Tahanan dasar panggul yang menolak kepala lebih ke depan.

\section{Putar Paksi Luar}

Kepala yang sudah lahir selanjutnya mengalami restitusi yaitu kepala janin memutar ke arah punggung janin untuk menghilangkan torsi pada leher yang terjadi karena putaran paksi dalam. Bahu melintasi pintu dalam keadaan miring, di dalam rongga panggul bahu akan menyesuaikan diri dengan bentuk panggul yang dilaluinya sehingga di dasar panggul setelah kepala bayi lahir, bahu akan mengalami putaran dalam di mana ukuran bahu (diameter bisa kromial) menempatkan diri dalam diameter anteroposterior dari pintu bawah panggul. Bersamaan dengan itu, kepala janin juga melanjutkan putaran sehingga belakang kepala berhadapan dengan tuber iskiadikum sepihak.

\section{Ekspulsi}

Setelah putaran paksi luar, bahu depan sampai bawah simfisis dan menjadi hipomoklion untuk kelahiran bahu belakang. Setelah kedua bahu lahir, selanjutnya seluruh badan bayi dilahirkan searah dengan sumbu jalan lahir.

Dengan kontraksi yang efektif, fleksi kepala yang adekuat dan janin dengan ukuran yang rata-rata sebagian besar oksiput yang posisinya posterior berputar cepat segera setelah mencapai dasar panggul sehingga persalinan tidak begitu bertambah lama. Akan 
tetapi kira-kira 5-10\% kasus, keadaan yang menguntungkan ini tidak terjadi, rotasi mungkin tidak sempurna atau mungkin tidak terjadi sama sekali khususnya kalau janin besar.

\subsection{FISIOLOGI NIFAS}

\section{Puerperium Normal dan Penanganannya}

\section{Pengertian}

Masa nifas (postpartum/puerperium) berasal dari bahasa latin, yaitu dari kata Puer yang artinya bayi dan Parous yang berarti melahirkan.

Masa nifas (puerperium) adalah periode waktu selama 6-8 minggu setelah persalinan. Proses ini dimulai setelah selesainya persalinan dan berakhir setelah alat-alat reproduksi kembali seperti keadaan semula sebelum hamil/tidak hamil sebagai akibat dari adanya perubahan fisiologi dan psikologi karena proses persalinan.

Periode masa nifas dibagi menjadi tiga periode yaitu sebagai berikut :

1. Periode Immediate Postpartum

Masa segera setelah plasenta lahir sampai dengan 24 jam dan pada masa ini sering terdapat banyak masalah seperti perdarahan.

2. Periode Early Postpartum (24 jam - 1 minggu)

Masa dimana involusi uterus harus dipastikan dalam keadaan normal, tidak ada perdarahan, lochea tidak berbau busuk, tidak terjadi demam, ibu cukup mendapatkan cairan dan makanan, serta ibu dapat menyusui dengan baik. 
3. Periode Late Postpartum (1-5 minggu)

Masa di mana perawatan dan pemeriksaan kondisi sehari-hari, serta konseling Keluarga Berencana.

\section{Pembagian masa nifas dibagi dalam tiga periode, yaitu}

1. Puerperium Dini yaitu kepulihan di mana ibu telah diperbolehkan berdiri dan berjalan-jalan.

2. Puerperium Intermedial yaitu kepulihan menyeluruh alat-alat genitalis yang lamanya 6-8 minggu.

3. Remote puerperium yaitu waktu yang diperlukan untuk pulih dan sehat sempurna terutama bila selama hamil atau waktu persalinan mempunyai komplikasi.

\section{Perubahan pada Masa Nifas}

Selama hamil, terjadi perubahan pada sistem tubuh wanita diantaranya terjadi perubahan pada sistem reproduksi, sistem pencernaan, sistem perkemihan, sistem muskuloskeletal, sistem hematologi dan perubahan pada tanda-tanda vital. Pada masa postpartum, perubahan-perubahan tersebut akan kembali menjadi seperti saat sebelum hamil yang disebut dengan involusi uterus.

Involusi uterus atau pengerutan uterus merupakan suatu proses di mana uterus kembali ke kondisi sebelum hamil dengan bobot hanya 60 gram. Proses involusi uterus sebagai berikut :

1. Autolisis

Autolisis adalah proses penghgancuran diri sendiri yang terjadi dalam otot uterus. Enzim proteolitik akan memendekkan jaringan otot yang telah mengendur hingga panjangnya $10 \mathrm{kali}$ panjang sebelum hamil dan lebarnya 5 kali lebar sebelum hamil yang terjadi selama kehamilan.

2. Terdapat polymorph phagolitik dan makrofag di dalam sistem vaskular dan sistem limfatik. 
3. Efek oksitosin atau cara kerja oksitosin.

Oksitosin menyebabkan terjadinya kontraksi dan retraksi otot uteri sehingga akan menekan pembuluh darah yang mengakibatkan berkurangnya suplai darah ke uterus. Proses ini membantu untuk mengurangi situs atau tempat implantasi plasenta dan mengurangi perdarahan.

\section{Uterus}

Uterus secara berangsur-angsur menjadi kecil (involusi) sehingga akhirnya kembali seperti sebelum hamil.

1. Bayi lahir fundus uteri setinggi pusat dengan berat uterus 1.000 gr.

2. Akhir kala III persalinan, tinggi fundus uteri teraba 2 jari bawah pusat dengan berat 750 gram.

3. Satu minggu postpartum tinggi fundus uteri teraba pertengahan pusat simfisis dengan berat uterus 500 gram.

4. Dua minggu postpartum tinggi fundus uteri tidak teraba di atas simfisis dengan berat uterus 350 gram.

5. Enam minggu postpartum fundus uteri bertambah kecil dengan berat uterus 50 gram.

Perubahan uterus pada masa nifas.

\begin{tabular}{l|l|l|l}
\hline \multicolumn{1}{c|}{ Waktu } & \multicolumn{1}{c|}{$\begin{array}{c}\text { Bobot } \\
\text { uterus }\end{array}$} & $\begin{array}{c}\text { Diameter } \\
\text { uterus }\end{array}$ & \multicolumn{1}{|c}{$\begin{array}{c}\text { Palpasi } \\
\text { serviks }\end{array}$} \\
\hline Pada akhir Persalinan & 900 gram & $12,5 \mathrm{~cm}$ & $\begin{array}{l}\text { Lembut } \\
/ \text { lunak }\end{array}$ \\
\hline Akhir minggu ke-1 & 450 gram & $7,5 \mathrm{~cm}$ & $2 \mathrm{~cm}$ \\
\hline Akhir minggu ke-2 & 200 gram & $5,0 \mathrm{~cm}$ & $1 \mathrm{~cm}$ \\
\hline
\end{tabular}




\begin{tabular}{l|l|l|l}
\hline Akhir minggu ke-6 & 60 gram & $2,5 \mathrm{~cm}$ & menyempit \\
\hline
\end{tabular}

Tinggi Fundus Uteri dan berat uterus selama involusi.

\begin{tabular}{l|l|l}
\hline \multicolumn{1}{c|}{ Involusi } & \multicolumn{1}{|c|}{ Tinggi Fundus Uteri } & Berat Uterus \\
\hline Bayi lahir & Setinggi umbilikus & 1.000 gram \\
\hline 1 minggu & Pertengahan pusat-simfisis & 750 gram \\
\hline 2 minggu & Tidak teraba diatas simfisis & 500 gram \\
\hline 6 minggu & Normal & 50 gram \\
\hline 8 minggu & Normal seperti sebelum hamil & 30 gram \\
\hline
\end{tabular}

Pengurangan dalam ukuran uterus tidak akan mempengaruhi jumlah otot sel yang terdapat di uterus. Pembuluh darah uterus yang besar pada masa kehamilan sudah tidak diperlukan lagi pada masa nifas karena uterus yang tidak pada keadaan hamil tidak mempunyai permukaan yang luas dan besar yang memerlukan banyak darah. Pembuluh darah tersebut akan menua kemudian menjadi hilang dengan penyerapan kembali endapan-endapan hialin sehingga dianggap telah digantikan dengan pembuluh darah baru yang lebih kecil.

\section{Lochea}

Dengan adanya involusi uterus maka lapisan luar dari desidua yang mengelilingi situs plasenta akan menjadi nekrotik (layu/mati). Desidua yang mati akan keluar bersama dengan sisa cairan. Campuran antara darah dan desidua tersebut dinamakan lochea yang biasanya berwarna merah muda atau putih pucat.

Lochea atau lokia adalah sekresi cairan rahim selama masa nifas dan mempunyai reaksi basa/alkalis yang dapat membuat organisme berkembang lebih cepat daripada kondisi asam yang ada pada vagina normal. Lokia mempunyai bau amis (anyir) 
meskipun tidak terlalu menyengat dan volumenya berbeda-beda pada setiap wanita. Lokia mengalami perubahan karena proses involusi. Pengeluaran lokia dapat dibagi berdasarkan waktu dan warnanya. Pada ibu nifas jumlah lokia yang sedikit pada saat ibu berbaring dan jumlahnya meningkat pada saat ibu berdiri. Jumlah rata-rata pengeluaran lokia adalah berkisar 240-270 $\mathrm{ml}$ per hari.

\section{Jenis -jenis lochea (lokia).}

\begin{tabular}{l|l|l|l}
\hline \multicolumn{1}{c|}{ Lokia } & \multicolumn{1}{|c|}{ Waktu } & \multicolumn{1}{c}{ Warna } & \multicolumn{1}{c}{ Ciri-ciri } \\
\hline Rubra & 1-3 hari & $\begin{array}{l}\text { Merah } \\
\text { kehitaman }\end{array}$ & $\begin{array}{l}\text { Terdiri atas sel desidua, } \\
\text { verniks caseosa, rambut } \\
\text { lanugo, sisa mekonium, } \\
\text { dan sisa darah }\end{array}$ \\
\hline sanguinolenta & $3-7$ hari & $\begin{array}{l}\text { Putih } \\
\text { bercampur } \\
\text { merah }\end{array}$ & $\begin{array}{l}\text { Sisa darah bercampur } \\
\text { lendir }\end{array}$ \\
\hline Serosa & 7-14 hari & $\begin{array}{l}\text { Kekuningan } \\
\text { /kecoklatan }\end{array}$ & $\begin{array}{l}\text { Lebih sedikit darah, lebih } \\
\text { banyak serum,leukosit } \\
\text { dan robekan laserasi } \\
\text { plasenta }\end{array}$ \\
\hline Alba & $>14$ hari & Putih & $\begin{array}{l}\text { Mengandung leukosit, } \\
\text { selaput lendir serviks } \\
\text { dan serabut jaringan } \\
\text { mati }\end{array}$ \\
\hline
\end{tabular}

\section{Serviks}

Serviks mengalami involusi bersama-sama uterus. Setelah persalinan ostium eksterna dapat dimasuki oleh 2 hingga 3 jari tangan. Setelah 6 minggu persalinan serviks akan menutup.

\section{Vulva dan Vagina}

Vulva dan vagina mengalami penekanan dan peregangan sangat besar selama melahirkan bayi. Dalam beberapa hari pertama sesudah proses tersebut, kedua organ ini tetap berada dalam keadaan kendur. Setelah tiga minggu vulva dan vagina kembali 
kepada keadaan saat tidak hamil dan rugae dalam vagina secara berangsur-angsur akan muncul kembali sementara labia menjadi lebih menonjol.

\section{Endometrium}

Timbulnya trombosis, degenerasi dan nekrosis di tempat implantasi plasenta. Pada hari pertama tebal endometrium 2,5 $\mathrm{mm}$ mempunyai permukaan yang kasar akibat pelepasan desidua dan selaput janin. Setelah tiga hari mulai rata sehingga tidak ada pembentukan jaringan parut pada bekas implantasi plasenta.

\section{Perineum}

Segera setelah melahirkan, perineum menjadi kendur karena sebelumnya teregang oleh tekanan kepala bayi yang bergerak maju. Pada postnatal hari kelima, perineum sudah mendapatkan kembali sebagian besar tonusnya sekalipun tetap lebih kendur daripada keadaan sebelum melahirkan.

\section{Payudara}

Perubahan pada payudara dapat meliputi hal-hal sebagai berikut :

1. Penurunan kadar progesteron secara tepat dengan peningkatan hormon prolaktin setelah persalinan.

2. Kolostrum sudah ada saat persalinan, produksi ASI terjadi pada hari kedua atau hari ketiga setelah persalinan.

3. Payudara menjadi besar dan kasar sebagai tanda mulainya proses laktasi.

Selama masa kehamilan jaringan payudara tumbuh dan menyiapkan fungsinya untuk menyediakan makanan bagi bayi. Setelah melahirkan, ketika hormon yang dihasilkan plasenta tidak ada lagi untuk menghambatnya, kelenjar pituitari akan mengeluarkan prolaktin. Sampai hari ketiga setelah melahirkan, 
efek prolaktin pada payudara mulai bisa dirasakan. Pembuluh darah payudara menjadi bengkak terisi darah sehingga timbul rasa hangat, bengkak dan rasa sakit. Sel-sel yang menghasilkan ASI juga mulai berfungsi.

\section{Sistem Perkemihan}

Buang air kecil sering sulit selama 24 jam pertama. Kemungkinan terdapat spasme sfingter dan edema leher buli-buli sesudah bagian ini mengalami kompresi antara kepala janin dan tulang pubis selama persalinan.

Urine dalam jumlah yang besar akan dihasilkan dalam waktu 12-36 jam sesudah melahirkan. Setelah plasenta dilahirkan, kadar hormon estrogen yang bersifat menahan air akan mengalami penurunan yang mencolok. Keadaan ini menyebabkan diuresis. Ureter yang berdilatasi akan kembali normal dalam waktu 6 minggu.

\section{Sistem gastroinstentinal}

Sering kali diperlukan waktu 3-4 hari sebelum faal usus kembali normal. Meskipun kadar progesteron menurun setelah melahirkan, namun asupan makanan juga mengalami penurunan selama satu atau dua hari dan gerak tubuh yang berkurang. Rasa sakit di daerah perineum dapat menghalangi keinginan buang air besar.

\section{Sistem Kardiovaskular}

Selama kehamilan volume darah normal digunakan untuk menampung aliran darah yang meningkat, yang diperlukan oleh plasenta dan penampung darah uterin. Penarikan kembali esterogen menyebabkan diuresis terjadi, yang secara cepat mengurangi volume plasma kembali pada proporsi normal. 
Aliran ini terjadi dalam 2-4 jam pertama setelah kelahiran bayi. Selama masa ini ibu mengeluarkan banyak sekali jumlah urine. Hilangnya progesteron membantu mengurangi retensi cairan yang melekat dengan meningkatnya vaskular pada jaringan tersebut selama kehamilan bersama-sama dengan trauma selama persalinan.

Pada persalinan per vaginam dapat mengalami kehilangan darah sekitar 300-400 cc. Apabila kelahiran melalui SC, maka kehilangan darah dapat dua kali lipat. Perubahan terdiri dari volume darah dan hematokrit. Pada persalinan per vaginam, hematokrit akan naik sedangkan pada persalinan Sc hematokrit cenderung stabil dan kembali normal setelah 4-6 minggu.

Setelah persalinan, shunt akan hilang dengan tiba-tiba. Volume darah ibu relatif akan bertambah. Keadaan ini akan menimbulkan beban pada jantung, dapat menimbulkan decompensation cordial pada penderita vitum cordial. Keadaan ini dapat diatasi dengan mekanisme kompensasi dengan timbulnya hemokonsentrasi sehingga volume darah kembali seperti sediakala umumnya hal ini terjadi pada hari 3-5 postpartum.

\section{Sistem Endokrin}

1. Hormon plasenta.

Hormon plasenta menurun dengan cepat setelah persalinan. Human Chorionic Gonadotrophin (hCG) menurun dengan cepat dan menetap sampai $10 \%$ dalam 3 jam hingga hari ke-7 postpartum dan sebagai onset pemenuhan mamae pada hari ke-3 postpartum.

2. Hormon pituitari.

Prolaktin darah meningkat dengan cepat, pada wanita menyusui menurun dalam waktu 2 minggu. FSH dan $\mathrm{LH}$ meningkat pada fase konsentrasi folikuler pada minggu ke-3 dan LH tetap rendah hingga ovulasi terjadi. 
3. Hipotalamik pituitari ovarium.

Untuk wanita yang menyusui dan tidak menyusui akan mempengaruhi lamanya ia mendapatkan menstruasi. Sering kali menstruasi pertama bersifat anovulasi yang dikarenakan rendahnya kadar estrogen dan progesteron. Pada wanita laktasi, sekitar $15 \%$ memperoleh menstruasi setelah 6 minggu dan $45 \%$ setelah 12 minggu. Di antara wanita yang tidak laktasi 40\% akan mengalami menstruasi setelah 6 minggu, 65\% setelah 12 minggu, dan $90 \%$ setelah 24 minggu. Untuk wanita laktasi, $80 \%$ menstruasi pertama anovulasi dan untuk wanita yang tidak laktasi $50 \%$ siklus pertama anovulasi.

\section{Sistem Muskuloskeletal}

Ambulasi pada umumnya dimulai 4-8 jam postpartum. Ambulasi dini sangat membantu untuk mencegah komplikasi dan mempercepat proses involusi.

Ligamen, fasia dan diafragma pelvis yang meregang pada waktu persalinan, setelah bayi lahir secara berangsur-angsur menjadi ciut dan pulih kembali sehingga tidak jarang uterus jatuh ke belakang dan menjadi retrofleksi karena ligamen rotundum menjadi kendor. Stabilisasi secara sempurna terjadi pada 6-8 minggu setelah persalinan.

Sebagai akibat putusnya serat-serat elastik kulit dan distensi yang berlangsung lama akibat besarnya uterus pada saat hamil, dinding abdomen masih lunak dan kendur untuk sementara waktu. Pemulihan dibantu dengan latihan.

\section{Sistem Hematologi}


Selama minggu-minggu terakhir kehamilan, kadar fibrinogen dan plasma, serta faktor-faktor pembekuan darah meningkat. Pada hari pertama postpartum kadar fibrinogen dan plasma akan sedikit menurun, tetapi darah lebih mengental dan terjadi peningkatan viskositas sehingga meningkatkan faktor pembekuan darah. Leukositosis yang meningkat di mana jumlah sel darah putih dapat mencapai 15.000 selama persalinan akan tetap tinggi dalam beberapa hari pertama dari masa postpartum.

Jumlah sel darah putih tersebut masih dapat naik lagi sampai 25.000 atau 30.000 tanpa adanya kondisi patologis jika wanita tersebut mengalami persalinan lama. Jumlah hemoglobin, hematokrit dan eritrosit akan sangat bervariasi pada awal-awal masa postpartum sebagai akibat dari volume darah, volume plasenta dan tingkat volume darah yang berubah-ubah.

Semua tingkatan ini akan dipengaruhi oleh status gizi dan hidrasi wanita tersebut. Kira-kira selama kelahiran dan masa postpartum, terjadi kehilangan darah sekitar 200-500 ml. Penurunan volume dan peningkatan sel darah pada kehamilan diasosiasikan dengan peningkatan hematokrit dan hemoglobin pada hari ke 3-7 postpartum dan akan kembali normal dalam 4-5 minggu postpartum.

\section{Tanda-tanda Vital}

\section{Suhu tubuh.}

Satu hari (24 jam) postpartum suhu badan akan naik sedikit (37,5-38 C) sebagai akibat kerja keras waktu melahirkan, kehilangan cairan, dan kelelahan. Apabila keadaan normal suhu badan menjadi biasa. Biasanya pada hari ketiga suhu badan naik lagi karena adanya pembentukan ASI, payudara menjadi bengkak, berwarna merah karena banyaknya ASI. Bila suhu tidak turun kemungkinan adanya infeksi pada endometrium, mastitis, traktus genitalis, atau sistem lain. 


\section{Nadi.}

Denyut nadi normal pada orang dewasa 60-80 kali per menit. Sehabis melahirkan biasanya denyut nadi akan lebih cepat.

\section{Tekanan darah.}

Biasanya tidak berubah, kemungkinan tekanan darah akan rendah setelah ibu melahirkan karena adanya perdarahan. Tekanan darah tinggi pada postpartum dapat menandakan terjadinya preeklamsia postpartum.

4. Pernapasan.

Keadaan pernafasan selalu berhubungan dengan keadaan suhu dan denyut nadi. Bila suhu nadi tidak normal, pernafasan juga akan mengikutinya, kecuali apabila ada gangguan khusus pada saluran nafas.

\section{Penanganan}

\section{Mobilisasi.}

Kini perawatan puerpurium lebih aktif dengan menganjurkan ibu nifas untuk melakukan mobilisasi dini (early mobilization). Hal ini mempunyai keuntungan yaitu sebagai berikut :

a. Memperlancarkan pengeluaran lochea.

b. Mempercepat involusi.

c. Memperlancar fungsi alat gastrointestinal dan alat perkemihan.

d. Meningkatkan kelancaran peredaran darah sehingga mempercepat fungsi ASI dan pengeluaran sisa metabolisme.

\section{Diet.}

Ibu harus mengkonsumsi tambahan 500 kalori tiap hari, makan dengan diet seimbang untuk mendapatkan protein, mineral, dan vitamin yang cukup, minum minimal 3 liter air setiap hari, makan tablet zat besi setidaknya selama 40 hari pasca melahirkan, dan makan kapsul vitamin A (200.000 unit).

\section{Buang Air Kecil.}


Hendaknya buang air kecil dapat dilakukan sendiri secepatnya. Kadang-kadang wanita mengalami sulit untuk buang air kecil, karena sfingter uretra ditekan oleh kepala janin dan spasme oleh iritasi muskulus spingter ani selama persalinan.

\section{Defekasi.}

Buang air besar harus dilakukan 3-4 hari pasca-persalinan. Ibu dianjurkan banyak mengkonsumsi buah-buahan. Bila masih sulit buang air besar dan terjadi obstipasi apalagi buang air besar keras dapat diberikan obat laksatif peroral atau per rektal.

\section{Kebersihan diri.}

Anjurkan pada ibu untuk membersihkan daerah kelamin dengan sabun dan air serta anjurkan pada ibu untuk mengganti pembalut minimal $2 x$ sehari.

6. Istirahat.

Anjurkan pada ibu untuk istirahat yang cukup dan melakukan kegiatan rumah tangga secara hati-hati.

\section{Latihan.}

Menjelaskan bahwa latihan menggerakkan otot-otot perut dan panggul sangat penting. Ibu bisa melakukan latihan beberapa menit setiap hari.

\section{Senggama.}

Secara fisik aman untuk memulai hubungan suami istri begitu darah berhenti dan ibu tidak mengalami nyeri.

\section{Keluarga Berencana.}

Idealnya pasangan harus menunggu minimal 2 tahun sebelum ibu hamil kembali. Setiap pasangan harus menentukan sendiri kapan dan bagaimana mereka ingin merencanakan keluarganya. 


\section{BAB 6 STRUKTUR PAYUDARA DAN FISIOLOGI LAKTASI}

Menyusui adalah proses pemberian susu kepada bayi atau anak kecil dengan air susu ibu (ASI) dan payudara ibu. Bayi menggunakan refleks mengisap untuk mendapatkan dan menelan susu. Bukti eksperimental menyimpulkan bahwa Air Susu Ibu adalah gizi yang terbaik untuk bayi. Para pakar masih memperdebatkan berapa lama periode menyusui yang paling baik dan seberapa jauh risiko penggunaan susu formula.

Seorang bayi dapat disusui oleh ibunya sendiri atau wanita lain. Air Susu Ibu juga dapat diperoleh dan diberikan melalui alat menyusui lain, seperti botol susu, cangkir, sendok, atau pipet. Susu formula juga tersedia bagi pada ibu yang tidak bisa menyusui atau memilih untuk tidak menyusui bayinya, namun para ahli sepakat bahwa kualitas susu formula tidak ada yang sebaik air susu ibu. Pada banyak negara, pemberian susu formula terkait dengan tingkat kematian bayi akibat diare, tetapi apabila pembuatannya dilakukan dengan hati-hati dan bersih maka susu formula cukup aman. 
Pemerintah dan organisasi internasional sepakat untuk mempromosikan menyusui sebagai metode terbaik untuk pemberian gizi bayi setidaknya tahun pertama bahkan lebih lama lagi. Organinsasi tersebut antara lain WHO, American Academy of Pediatrics dan Departemen Kesehatan.

126

\subsection{STRUKTUR PAYUDARA}

\section{Anatomi Payudara}

Kelenjar mamae atau payudara (buah dada) adalah perlengkapan pada organ reproduksi pada wanita dan mengeluarkan air susu. Pada wanita kelenjar mamae mulai berkembang pada umur 11-12 tahun. Kelenjar mamae tumbuh menjadi besar pada bagian lateral linea aksilaris anterior/media sebelah kranial ruang interkostalis III dan sebelah kaudal ruang interkostalis VII-VIII.

Kelenjar mamae terdapat di atas bagian luar fasia torakalis superfisialis di daerah jaringan lemak subkutia. Ke arah lateral sampai ke linea aksilaris media, ke arah medial melewati linea media mencapai kelenjar mamae sisi yang lain, ke arah bawah mencapai daerah aksila (lipatan ketiak). 


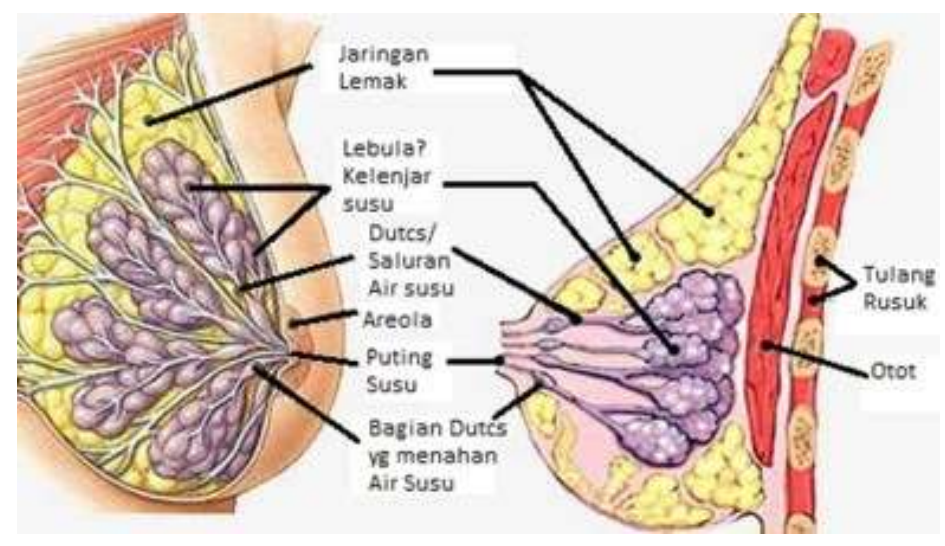

GAMBAR 6-1 Anatomi payudara

\section{Struktur makroskopis}

Ada tiga bagian utama payudara, yaitu sebagai berikut:

1. Korpus (badan) yaitu bagian yang membesar.

2. Areola yaitu bagian yang kehitaman di tengah.

3. Papilla atau puting, yaitu bagian yang menonjol di puncak payudara.

Terletak setinggi interkosta IV, tetapi berhubung adanya variasi bentuk dan ukuran payudara, maka letaknya pun akan bervariasi pula. Pada tempat ini terdapat lubang-lubang kecil yang merupakan muara dari duktus laktiferus, ujung-ujung saraf, pembuluh darah, pembuluh getah bening, serat-serat otot polos yang tersusun secara sirkuler sehingga bila ada kontraksi, maka duktus laktiferus akan memadat dan menyebabkan puting susu ereksi sedangkan serat-serat otot yang longitudinal akan menarik kembali puting susu tersebut.

Ada empat macam bentuk puting, yaitu bentuk normal/umum, pendek/datar, panjang dan terbenam (inverted). Namun, bentuk- 
bentuk puting ini tidak selalu berpengaruh pada proses laktasi karena pada dasarnya bayi menyusu pada payudara ibu bukan pada puting. Pada beberapa kasus dapat terjadi di mana puting tidak lentur, terutama pada bentuk puting terbenam sehingga butuh penanganan khusus.

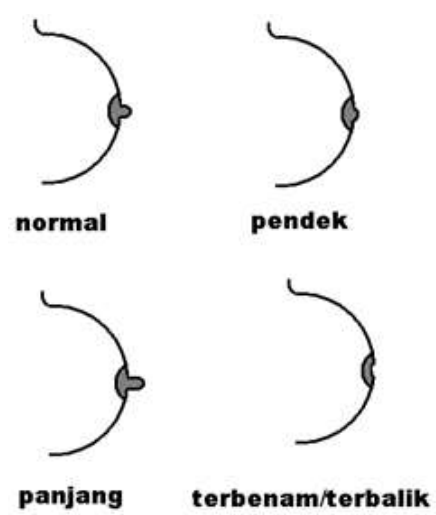

GAMBAR 6-2 Bentuk-bentuk puting

\section{Struktur Mikroskopis}

Pada bagian dalam badan payudara terdapat bangunan yang disebut alveolus, yang merupakan tempat air susu diproduksi. Air Susu Ibu yang dihasilkan oleh alveolus dialirkan ke dalam saluran kecil (diktulus) lalu beberapa saluran kecil yang bergabung membentuk saluran yang lebih kecil (duktus). Pada bagian bawah areola, saluran yang besar ini mengalami pelebaran yang disebut sinus laktiferus. Akhirnya semua saluran yang besar ini terpusat di dalam puting dan bermuara ke luar. Pada bagian dalam dinding alveolus maupun saluran, terdapat otot polos yang bila berkontraksi dapat memompa ASI keluar.

Masing-masing payudara terdiri atas 15-20 lobus, yang dipisahkan oleh jaringan ikat, mengandung jaringan glandular yang 
tersusun sebagai suatu sistem duktus-alveolus. Pada masingmasing lobus terdiri atas 20-40 lobus, selanjutnya masing-masing lobulus terdiri atas 10-100 alveoli. Bagian dalam alveoli terdiri atas duktulus terbuka, sel-sel kelenjar yang menghasilkan air susu dan mioepitelium yang berfungsi memeras air susu keluar dari alveoli.

Pembuluh darah payudara berasal dari arteri mammaria interna dan arteri torakalis lateralis (artery thoracica lateralis). Vena superfisial mamae mempunyai banyak anastomosis bermuara ke vena mammaria interna dan vena torakalis interna (vena thoracica interna/epigastrika), sebagian besar bermuara ke vena torakalis lateralis (vena thoracica lateralis).

\section{Pembuluh Limfe Mamae}

1. Aliran limfe superfisialis $75 \%$ mengalir ke saluran trokalis berjalan bersama arteri dan vena di pinggir lateral muskulus pektoralis mayor (musculus pektoralis mayor) bermuara di nervus 11 aksilaris dan nervus supraklavikularis (nervus supraclavicularis).

2. Aliran limfe profunda mengalir ke dinding toraks menembus muskulus pektoralis mayor bermuara ke nervus 11 pektoralis sepanjang arteri dan vena mammaria interna.

3. Bagian medial aliran limfe subkutan berhubungan dengan kedua mamae dan bermuara ke nervus 11 supraklavikularis.

\subsection{TAHAP PERKEMBANGAN PAYUDARA}

Pembentukan payudara dimulai sejak embrio berusia 18-19 tahun dan berakhir ketika mulai menstruasi. Hormon yang berperan adalah hormon estrogen dan progesteron yang membantu maturasi alveoli, sedangkan hormon prolaktin berfungsi untuk produksi ASI. 
Saat lahir, sebagian besar payudara terdiri atas duktus laktiferus dengan jumlah sedikit, mungkin juga ada alveoli. Kelenjar mammae yang rudimeter ini memiliki sedikit fungsi sekretorik (air susu palsu) dalam beberapa hari setelah lahir. Sekresi payudara pada masa neonatal terjadi akibat kadar prolaktin yang tinggi pada bayi baru lahir setelah pajanan payudara janin sebelumnya terhadap konsentrasi esterogen plasenta yang tinggi selama kehamilan. Setelah esterogen plasenta hilang dari sirkulasi neonatal, payudara memasuki fase tenang sampai pubertas.

Pada onset pubertas,esterogen ovarium menginduksi pertumbuhan sistem duktus laktiferus. Duktus-duktus ini bercabang-cabang selama pertumbuhannya dan ujung duktus ini membentuk massa sel kecil dan padat. Struktur ini akan membentuk alveolus lobular. Payudara dan alveoli kemudian membesar.

Saat menarche, sekresi esterogen dan progesteron siklik dimulai dan akan terjadi fase tambahan pada pertumbuhan duktus dan lobulus yang rudimeter. Kortikosteroid adrenal selanjutnya akan meningkatkan perkembangan duktus. Payudara terus membesar selama beberapa waktu setelah menarche akibat timbunan lemak dan jaringan ikatan. Diferensiasi dan pertumbuhan akhir payudara tidak akan terjadi sampai kehamilan terjadi.

Pertumbuhan dan perkembangan payudara dapat dibagi menjadi empat fase yaitu fase istirahat, perkembangan (kehamilan), sekresi susu (laktasi), dan involusi. Saat lahir, struktur hanya sebuah puting payudara dan duktus rudimenter dengan sedikit atau tanpa alveolus yang mencerminkan asal evolusi dari modifikasi kelenjar keringat apokria. Sampai pubertas, satusatunya perkembangan yang mungkin terjadi adalah percabangan duktus. Penurunan insiden kanker payudara dapat terjadi pada 
populasi yang banyak mengkonsumsi fito-estrogen merangsang perkembangan sel payudara pada masa anak dan pubertas sebelum kehamilan. Sel yang berdiferensiasi baik ini mungkin lebih resisten terhadap pembentukan tumor.

\section{Kolostrum}

kolostrum adalah cairan pra-susu yang dihasilkan dalam 24-36 jam pertama setelah melahirkan (pasca-persalinan). Kolostrum mengandung sel darah putih dan antibodi yang paling tinggi daripada ASI sebenarnya, khususnya kandungan immunoglobulin A ( Ig A) yang membantu melapisi usus bayi yang masih rentan dan mencegah kuman memasuki bayi. Ig $A$ ini juga membantu dalam mencegah bayi mengalami alergi makanan.

Kolostrum merupakan cairan yang pertama kali disekresi oleh kelenjar payudara. Kolostrum mengandung jaringan debris dan material residual yang terdapat dalam alveoli serta duktus dari kelenjar payudara sebelum dan setelah masa puerperium.

\section{Beberapa manfaat kolostrum bagi bayi adalah sebagai berikut:}

1. Menjadi pencahar yang ideal untuk membersihkan mekoneum dari usus bayi yang baru lahir dan mempersiapkan saluran pencernaan bayi yang akan datang.

2. Lebih banyak mengandung protein dibandingkan dengan ASI yang matur, tetapi berlainan dengan ASI yang telah matur, pada kolostrum protein yang utama adalah globulin (gamma globulin).

3. Lebih banyak mengandung antibodi dibandingkan dengan ASI yang matur sehingga dapat memberikan perlindungan bagi bayi sampai usia 6 bulan.

4. Kadar karbohidrat dan lemak rendah jika dibandingkan dengan ASI matur.

5. Mineral terutama natrium, kalium, dan klorida lebih tinggi dibandingkan dengan susu matur. 
6. Total energi lebih rendah jika dibandingkan dengan suus matur, hanya $58 \mathrm{kal} / 100 \mathrm{ml}$ kolostrum.

7. Vitamin yang larut dalam lemak lebih tinggi jika dibandingkan dengan ASI matur, sedangkan vitamin yang larut dalam air dapat lebih tinggi atau lebih rendah.

8. Bila dipanaskan akan menggumpal sedangkan ASI matur tidak.

9. Kada $\mathrm{pH}$ lebih alkalis dibandingkan dengan ASI matur.

10.Lipidnya lebih banyak mengandung kolesterol dan lesitin dibandingkan dengan ASI matur.

11. Volume berkisar $150-300 \mathrm{ml} / 24 \mathrm{jam}$.

12.Terdapat tripsin inhibitor sehingga hidrolis protein di dalam usus bayi menjadi kurang sempurna. Hal ini akan lebih banyak menambah kadar antibodi pada bayi.

\section{Fisiologi Laktasi}

Laktasi berarti suatu proses produksi, sekresi dan pengeluaran ASI yang membutuhkan calon ibu yang siap secara psikologis dan fisik, kemudian bayi yang telah cukup sehat untuk menyusu serta produksi ASI yang telah disesuaikan dengan kebutuhan bayi dimana volume ASI 500-800 ml/hari.

Ketika bayi menghisap payudara, hormon yang bernama oksitosin membuat ASI mengalir dari dalam alveoli melalui saluran susu menuju ke reservoir susu yang berlokasi di belakang areola lalu ke dalam mulut bati. Pengaruh hormonal bekerja mulai dari bulan ketiga kehamilan di mana tubuh wanita memproduksi hormon yang menstimulasi munculnya ASI dalam sistem payudara. ASI adalah suatu emulsi lemak dalam larutan protein, laktosa dan garam-garam organik yang disekresi oleh kedua belah kelenjar payudara ibu sebagai makanan utama bagi bayi.

Sebagai persiapan menyongsong kelahiran bayi, perawatan payudara yang dimulai dari kehamilan bulan 7-8 memegang peranan penting dalam menentukan berhasilnya menyusui bayi. 
Payudara yang terawat akan memproduksi ASI cukup untuk memenuhi kebutuhan bayi. Begitu pula dengan perawatan payudara yang baik, ibu tidak perlu khawatir bentuk payudaranya akan cepat berubah sehingga kurang menarik. Dengan perawatan payudara yang baik, puting tidak akan lecet sewaktu dihisap oleh bayi.

\section{Siklus Laktasi}

1. Laktogenesis stadium 1 (kehamilan) : penambahan dan pembesaran lobulus alveolus.

2. Laktogenesis stadium 2 (akhir kehamilan sampai 2-3 hari postpartum) : produksi ASI.

3. Laktogenesis stadium 3 (galaktopoeisis) : sekresi ASI.

4. Involusi (berkurangnya kelenjar mammae) : mulai 40 hari setelah berhenti.

\section{Produksi Air Susu}

Proses laktasi merupakan suatu interaksi yang sangat kompleks antara rangsangan mekanik, saraf dan bermacam-macam hormon. Salah satunya pembentukan kelenjar payudara, yang dibagi menjadi beberapa tahap, antara lain sebagai berikut :

\section{Sebelum pubertas}

Duktus primer dan sekunder sudah terbentuk pada masa fetus. Mendekati pubertas terjadi pertumbuhan yang cepat dari sistem duktus terutama dibawah pengaruh hormon esterogen, sedangkan pertumbuhan alveoli oleh kelenjar adenohipofisis (hipofisis anterior). Hormon yang kurang peranannya adalah hormon adrenalin, paratiroid, tiroid dan hormon pertumbuhan. 


\section{Masa pubertas}

Pada masa ini terjadi pertumbuhan percabangan-percabangan sistem duktus, proloferasi dan kanalisasi dari unit-unit lobuloalveolar yang terletak pada ujung-ujung distal duktulus. Jaringan penyangga stroma mengalami organisasi dan membentuk septum interlobular.

\section{Masa siklus menstruasi}

Perubahan-perubahan kelenjar payudara wanita dewasa berhubungan dengan siklus menstruasi dan perubahanperubahan hormonal yang mengatur siklus tersebut seperti esterogen dan progesteron yang dihasilkan korpus luteum. Bila kadar hormon ini meningkat, maka akan terjadi edema lobulus, penebalan dari basal membran epite dan keluarnya bahan dalam alveoli. Secara klinis akan dirasakan payudara berat dan penuh. Setelah menstruasi, di mana kadar estrogen dan progesteron berkurang, yang berperan hanya prolaktin saja, terjadi degenerasi dari sel-sel kelenjar air susu beserta jaringan yang mengalami proliferasi, edema berkurang sehingga besarnya payudara berkurang namun tidak kembali seperti besar sebelumnya. Hal ini menyebabkan payudara selalu bertambah besar pada setiap siklus ovulasi mulai dari permulaan tahun menstruasi sampai umur 30 tahun.

\section{Masa kehamilan}

Pada permulaan kehamilan terjadi peningkatan yang jelas dari duktulus yang baru, percabangan-percabangan dan lobulus, yang dipengaruhi oleh hormon-hormon plasenta dan korpus luteum. Hormon-hormon yang ikut membantu mempercepat pertumbuhan adalah prolaktin, laktogen plasenta, korionik gonadotropin, insulin, hormon tiroid, kortisol, hormon paratiroid dan hormon pertumbuhan.

\section{Pada 3 bulan kehamilan}


Prolaktin dari adenohipofisis (hipofisis anterior) mulai merangsang kelenjar air susu untuk menghasilkan air susu yang disebut kolostrum. Pada masa ini, pengeluaran kolostrum masih dihambat oleh estrogen dan progesteron tetapi jumlah prolaktin meningkat hanya aktivitas dalam pembuatan kolostrum yang ditekan.

\section{Pada trimester kedua kehamilan}

Laktogen plasenta mulai merangsang untuk pembuatan kolostrum. Keaktifan dari rangsangan hormon-hormon terhadap pengeluaran air susu telah terbukti kebenarannya.

Proses produksi, sekresi dan pengeluaran ASI dinamakan laktasi, sedangkan ASI adalah cairan dengan komposisi khas untuk menjamin pertumbuhan optimal pada setiap spesies. Ketika bayi menghisap payudara, hormon yang bernama oksitosin membuat ASI mengalir dari dalam alveoli melalui saluran susu menuju ke reservoir susu yang berlokasi di belakang areola lalu ke dalam mulut bayi. Pengaruh hormonal bekerja mulai dari bulan ketiga kehamilan di mana tubuh wanita memproduksi hormon yang menstimulasi munculnya ASI dalam sistem payudara.

Persiapan memberikan ASI dilakukan bersamaan dengan kehamilan, payudara semakin padat karena retensi air, lemak dan berkembangnya kelenjar-kelenjar payudara yang dirasa tegang dan sakit. Segera setelah terjadi kehamilan, maka korpus luteum berkembang terus dan mengeluarkan estrogen dan progesteron untuk mempersiapkan payudara agar pada waktunya dapat memberikan ASI.

\subsection{HORMON-HORMON DALAM LAKTASI}


Laktasi merupakan proses produksi, sekresi dan pengeluaran ASI, sedangkan yang dimaksud dengan ASI adalah cairan dengan komposisi khas untuk menjamin pertumbuhan optimal bayi manusia. Persiapan bagi pemberian ASI berjalan seiring dengan proses kehamilan. Segera setelah terjadi kehamilan, korpus luteum berkembang terus dan mengeluarkan estrogen dan pprogesteron untuk mempersiapkan payudara agar pada waktu bayi lahir dapat langsung menghasilkan ASI.

Hormon - hormon yang dapat mempengaruhi pembentukan ASI selama kehamilan yaitu sebagai berikut :

\section{Progesteron}

Mempengaruhi pertumbuhan dan ukuran alveoli. Tingkat progesteron dan estrogen menurun sesaat setelah melahirkan. Hal ini menstimulasi produksi ASI secara besar-besaran.

\section{Estrogen}

Menstimulasi sistem saluran ASI untuk membesar dimana tingkat estrogen menurun pada saat melahirkan dan akan tetap rendah untuk beberapa bulan selama tetap menyusui.

\section{Prolaktin}

Berperan dalam membesarnya alveoli dalam kehamilan. Dalam fisiologi laktasi, prolaktin merupakan suatu hormon yang disekresi oleh glandula pituitari dan memiliki peranan penting untuk memproduksi ASI serta meningkat selama kehamilan. Kerja hormon ini dihambat oleh hormon plasenta. Peristiwa lepas atau keluarnya plasenta pada akhir proses persalinan akan membuat kadar hormon estrogen dan progesteron berangsur-angsur menurun sampai tingkat dapat dilepaskan dan diaktifkannya prolaktin. Peningkatan kadar prolaktin akan menghambat ovulasi sehingga dapat menjadi mempunyai fungsi kontrasepsi. Kadar prolaktin paling tinggi adalah pada 
malam hari dan penghentian pertama pemberian air susu dilakukan pada malam hari.

\section{Oksitosin}

Hormon ini dapat mengencangkan otot halus dalam rahim pada saat melahirkan dan setelahnya. Saat melahirkan, oksitosin juga mengencangkan otot halus di sekitar alveoli untuk memeras ASI menuju saluran susu. Oksitosin berperan dalam proses turunnya susu.

\section{Human Plasenta Laktogen (HPL)}

Sejak bulan kedua kehamilan, plasenta mengeluarkan banyak HPL yang berperan dalam pertumbuhan payudara, puting dan areola sebelum melahirkan. Pada bulan kelima dan keenam kehamilan, payudara siap memproduksi ASI. Namun, ASI juga bisa diproduksi tanpa kehamilan (induced lactation).

\subsection{FISIOLOGI LAKTASI DAN PROSES PEMBENTUKAN LACTOGEN}

Laktasi merupakan proses produksi, sekresi dan pengeluaran ASI yang membutuhkan ibu yang siap secara psikologis dan fisik, bayi yang cukup sehat untuk menyusu, serta produksi ASI yang disesuaikan dengan kebutuhan bayi.

Ketika bayi mengisap payudara hormon oksitosin membuat ASI mengalir dari dalam alveoli melalui saluran susu (duktus laktiferus) menuju ke resevoir susu (sinus laktiferus) yang berlokasi di belakang areola, lalu ke dalam mulut bayi. Pengaruh hormonal bekerja mulai dari bulan ketiga kehamilan dimana tubuh wanita memproduksi hormon yang menstimulasi munculnya ASI dalam sistem payudara.

Laktogenesis merupakan suatu istilah yang berarti inisiasi laktasi. Ini merupakan saat jaringan mammae mengalami perubahan dari keadaan nonlaktasi menjadi keadaan laktasi. Proses ini normalnya dikaitkan dengan akhir kehamilan atau di 
sekitar waktu persalinan. Namun, karena laktogenesis sangat bergantung pada sekumpulan khusus hormon (disebut kompleks hormon laktogenik), jaringan mammae dari sebagian besar kelenjar mammae dalam keadaan nonlaktasi juga dapat dikondisikan sehingga mengalami suatu tingkat laktogenesis dengan cara pemberian hormon-hormon tersebut dalam kadar tinggi. Pengkondisian ini bisa dilakukan bahkan pada wanita yang tidak hamil.

Laktogenesis melibatkan serangkaian perubahan selular dimana sel epitel mammae diubah dari keadaan nonsekretorik menjadi keadaan sekretorik. Perubahan tersebut terjadi dalam beberapa tahap sebagai berikut :

\section{Lactogenesis I}

Pada fase terakhir kehamilan, payudara wanita memasuki fase lactogenesis I. Saat itu payudara memproduksi kolostrum, yaitu berupa cairan kental yang kekuningan. Pada saat itu, tingkat progesteron yang tinggi mencegah produksi ASI sebenarnya. Akan tetapi, bukan merupakan masalah medis apabila ibu hamil mengeluarkan kolostrum sebelum lahirnya bayi dan hal ini juga bukan indikasi sedikit atau banyaknya produksi ASI sebenarnya nanti.

\section{Lactogenesis II}

Saat melahirkan, keluarnya plasenta menyebabkan turunnya tingkat hormon estrogen, progesteron dan HPL secara tiba-tiba namun hormon prolaktin tetap tinggi. Hal ini menyebabkan produksi ASI secara besar-besaran yang dikenal dengan fase lactogenesis II.

Apabila payudara dirangsang, level prolaktin dalam darah meningkat, memuncak dalam periode 45 menit dan kemudian kembali ke level sebelum rangsangan tiga jam kemudian. 
Keluarnya hormon prolaktin menstimulasi sel di dalam alveoli untuk memproduksi ASI dan hormon ini juga keluar dalam ASI itu sendiri. Penelitian mengindikasikan bahwa level prolaktin dalam susu lebih tinggi apabila produksi ASI lebih banyak, yaitu sekitar pukul 2 pagi hingga 6 pagi, namun level prolaktin rendah saat payudara terasa penuh.

Hormon lainnya, seperti insulin, tiroksin dan kortisol juga terdapat dalam proses ini, namun peran hormon tersebut belum diketahui. Penanda biokimiawi mengindikasikan bahwa proses lactogenesis dimulai sekitar 30-40 jam setelah melahirkan, tetapi biasanya para ibu baru merasakan payudara penuh sekitar 50-73 jam (2-3 hari) setelah melahirkan. Hal ini berarti memang produksi ASI sebenarnya tidak langsung setelah melahirkan.

\section{Lactogenensis III}

Sistem kontrol hormon endokrin mengatur produksi ASI selama kehamilan dan beberapa hari pertama setelah melahirkan. Ketika produksi ASI mulai stabil, sistem kontrol autokrin dimulai. Fase ini dinamakan laktogenesis III. Pada tahap ini, apabila ASI banyak dikeluarkan, payudara akan memproduksi ASI dengan banyak pula. Penelitian berkesimpulan bahwa apabila payudara dikosongkan secara menyeluruh juga akan meningkatkan taraf produksi ASI. Dengan demikian, produksi ASI sangat dipengaruhi seberapa sering dan seberapa baik bayi mengisap, serta juga seberapa sering payudara dikosongkan.

Produksi ASI yang rendah diakibatkan oleh kurangnya menyusui atau memijat payudara. apabila bayi tidak bisa mengisap ASI secara efektif, hal ini dapat diakibatkan oleh struktur mulut dan rahang yang kurang baik, teknik perlekatan yang salah, kelainan endokrin ibu (jarang terjadi), jaringan payudara hipoplastik, kelainan metabolisme atau pencernaan bayi sehingga tidak dapat mencerna ASI serta kurangnya gizi ibu. 
Menyusui setiap dua-tiga jam akan menjaga produksi ASI tetap tinggi. Untuk wanita pada umumnya, menyusui, atau memeras ASI delapan kali dalam 24 jam akan menjaga produksi ASI tetap tinggi pada masa-masa awal menyusui, khususnya empat bulan pertama. Bukanlah hal yang aneh apabila bayi yang baru lahir menyusu lebih sering dari itu karena rata-rata bayi menyusui adalah 10-12 kali menyusui tiap 24 jam, atau bahkan 18 kali. Menyusui on-demand adalah menyusui kapan pun bayi meminta (artinya akan lebih banyak dari rata-rata). Cara ini merupakan cara terbaik untuk menjaga produksi ASI tetap tinggi dan bayi tetap kenyang. Akan tetapi perlu diingat, bahwa sebaiknya menyusui dilakukan dengan durasi yang cukup lama setiap kalinya dan tidak terlalu sebentar sehingga bayi menerima asupan foremilk dan hindmilk secara seimbang.

\section{Penghambat produksi ASI adalah sebagai berikut :}

1. Feedback inhibitor : suatu faktor lokal, bila saluran ASI penuh mengirim impuls untuk mengurangi produksi. Cara mengatasi : saluran dikosongkan secara teratur (ASI eksklusif dan tanpa jadwal).

2. Stres / rasa sakit : akan menghambat atau inhibisi pengeluaran oksitosin.

3. Penyapihan.

Kriteria yang digunakan untuk mengetahui jumlah ASI cukup atau tidak adalah sebagai berikut :

1. ASI yang banyak dapat merembes keluar melalui puting susu.

2. Sebelum disusukan pada bayi, payudara terasa tegang.

3. Berat badan bayi naik sesuai dengan umur.

4. Jika ASI cukup, setelah menyusu bayi akan tidur/tenang selama 3-4 jam.

5. Bayi berkemih sekitar 8 kali sehari. 


\section{Dua tanda yang menunjukkan bahwa bayi kurang mendapat cukup ASI adalah sebagai berikut :}

1. Urine bayi berwarna kekuningan pekat, berbau tajam dan jumlahnya sedikit. Bayi BAK kurang dari 6 kali sehari, keadaan ini menunjukkan bayi kekurangan cairan yang berasal dari ASI.

2. Perkembangan berat badan bayi kurang dari 500 gram per bulan dan ini menunjukkan bayi kurang mendapat asupan yang baik selama 1 bulan terakhir. Apabila diberikan ASI secara eksklusif (0-6 bulan) dapat mencukupi semua kebutuhan bayi.

Komposisi ASI tidak konstan dan tidak sama dari waktu ke waktu, yang dapat dipengaruhi oleh beberapa faktor, yaitu sebagai berikut:

1. Stadium laktasi.

2. Ras.

3. Keadaan nutrisi.

4. Diet ibu.

\section{Pengeluaran Air Susu}

Payudara menghasilkan ASI dimulai saat bayi mengisap payudara dan menstimulasi ujung saraf. Saraf memerintahkan otak untuk mengeluarkan dua hormon yaitu prolaktin dan oksitosin. Prolaktin merangsang alveoli untuk menghasilkan lebih banyak air susu. Oksitosin menyebabkan sel-sel otot di sekitar alveoli berkontraksi, mendorong air susu masuk ke saluran penyimpanan, dan akhirnya bayi dapat mengisapnya. Semakin bayi mengisap, semakin banyak susu yang dihasilkan.

Selama kehamilan hormon prolaktin dari plasenta meningkat tetapi ASI belum keluar karena pengaruh hormon estrogen yang masih tinggi. Kadar estrogen dan progesteron akan menurun pada saat hari kedua atau ketiga pasca-persalinan sehingga terjadi 
sekresi ASI. Pada proses laktasi terdapat dua refleks yang berperan, yaitu refleks prolaktin dan refleks aliran yang timbul akibat perangsangan puting susu dikarenakan isapan bayi.

\section{Refleks Prolaktin}

Refleks prolaktin adalah suatu stimuli atau perangsangan produksi ASI yang membutuhkan impuls saraf dari puting susu, hipotalamus, hipofisis anterior, prolaktin, alveolus, dan tentunya ASI itu sendiri.

Pada akhirnya kehamilan hormon prolaktin memegang peranan untuk membuat kolostrum, tetapi jumlah kolostrum terbatas dikarenakan aktivitas prolaktin dihambat oleh estrogen dan progesteron yang masih tinggi. Pascapersalinan, yaitu lepasnya plasenta dan berkurangnya fungsi korpus luteum, maka estrogen dan progesteron juga berkurang. Isapan bayi akan merangsang puting susu dan kalang payudara karena ujung-ujung saraf sensoris yang berfungsi sebagai reseptor mekanik.

Rangsangan ini dilanjutkan ke hipotalamus melalui medula spinalis hipotalamus dan akan menekan pengeluaran faktor penghambat sekresi prolaktin dan sebaliknya merangsang pengeluaran faktor pemacu sekresi prolaktin.

Faktor pemacu sekresi prolaktin akan merangsang hipofisis anterior sehingga keluar prolaktin. Hormon ini merangsang sel-sel alveoli yang berfungsi untuk membuat air susu. Kadar prolaktin pada ibu menyusui akan menjadi normal tiga bulan setelah melahirkan sampai penyapihan anak dan pada saat tersebut tidak akan ada peningkatan prolaktin walau ada isapan bayi, namun pengeluaran air susu tetap berlangsung.

Pada ibu nifas yang menyusui, kadar prolaktin akan menjadi normal pada minggu ke 2-3. Pada ibu menyusui, prolaktin akan meningkat dalam keadaan seperti : stres atau pengaruh psikis, anastesi, operasi dan rangsangan puting susu serta obat-obatan 
tranqulizer hipotalamus. Sementara itu, keadaan-keadaan yang menghambat pengeluaran prolaktin adalah gizi ibu yang buruk dan obat-obatan seperti ergot, I-dopa.

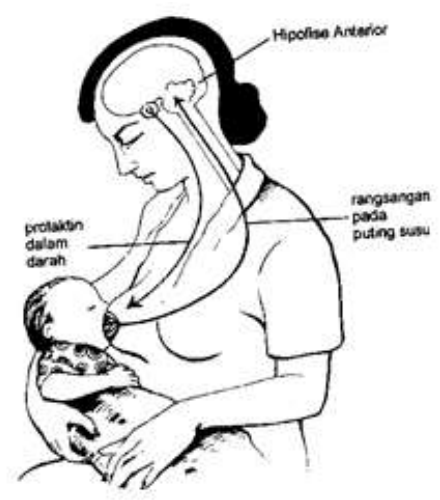

GAMBAR 6-3 Refleks prolaktin

\section{Refleks Aliran (Let Down Refleks)}

Refleks aliran yaitu sekresi atau pengeluaran ASI, impuls saraf, puting susu, hipofisis posterior, oksitosin, kontraksi otot polos supaya ASI keluar. Bersamaan dengan pembentukan prolaktin oleh hipofisis anterior, rangsangan yang berasal dari isapan bayi dilanjutkan ke hipofisis posterior (neurohipofisis) yang kemudian dikeluarkan oksitosin. Melalui aliran darah, hormon ini menuju uterus sehingga menimbulkan kontraksi pada uterus sehingga terjadi involusi dari organ tersebut. Oksitosin yang sampai pada alveoli akan mempengaruhi sel mioepitelium. Kontraksi dari sel akan memeras air susu yang telah terbuat, keluar dari alveoli dan 
masuk ke sistem duktus, selanjutnya mengalir melalui duktus laktiferus masuk ke mulut bayi.

Faktor-faktor yang meningkatkan refleks let down adalah melihat bayi, mendengarkan suara bayi, mencium bayi, dan memikirkan untuk menyusui bayi; sedangkan faktor-faktor yang menghambat refleks let down adalah stres, seperti keadaan bingung/pikiran kacau, takut dan cemas.

Bila ibu stres dalam menyusui, maka akan ada suatu blokade dari refleks let down. Keadaan ini disebabkan adanya pelepasan dari adrenalin (epinefrin) yang menyebabkan vasokontriksi dari pembuluh darah alveoli sehingga oksitosin tidak dapat mencapai organ mioepitelium. Akibatnya akan terjadi penumpukan air susu di dalam alveoli yang secara klinis tampak payudara membesar. Payudara yang besar dapat berakibat abses, gagal untuk menyusui dan rasa sakit.

\section{Mekanisme Menyusui}

Bayi yang sehat mempunyai tiga refleks intrinsik yang dibutuhkan agar menyusui berhasil.

\section{Refleks Menangkap (Rooting Refleks)}

Refleks ini terlihat saat bayi baru lahir tersentuh pipinya, bayi akan menoleh ke arah sentuhan. Bibir bayi dirangsang dengan papilla mamae, maka bayi akan membuka mulut dan berusaha menangkap puting susu.

\section{Refleks Mengisap (Sucking Refleks)}

Refleks ini timbul apabila langit-langit mulut bayi tersentuh oleh puting. Sebagian besar areola masuk ke dalam mulut bayi agar puting dapat mencapai palatum. Dengan demikian sinus 
laktiferus yang berada di bawah areola akan tertekan antara gusi, lidah, dan palatum sehingga ASI keluar.

\section{Refleks Menelan (Swallowing Refleks)}

Pada saat air susu keluar dari puting susu, akan disusul dengan gerakan mengisap (tekanan negatif) yang ditimbulkan oleh otot-otot pipi sehingga pengeluaran air susu akan bertambah dan diteruskan dengan mekanisme menelan masuk ke lambung.

\section{Pemeliharaan Laktasi}

Ketersediaan ASI pada ibu menyusui berlangsung sesuai kebutuhan. Bila bayi tidak disusui, maka ASI tidak akan keluar. Makin sering bayi disusui, maka penyediaan ASI juga semakin baik. Faktor penting untuk pemeliharaan laktasi adalah rangsangan dan pengosongan payudara secara sempurna.

\section{Rangsangan}

Sebagai respon terhadap pengisapan, prolaktin dikeluarkan dari glandula pituitaria anterior, dengan demikian dapat memacu pembentukan air susu yang lebih banyak. Apabila karena suatu alasan tertentu bayi tidak dapat menyusu sejak awal, maka ibu dapat memeras air susu dari payudaranya dengan tangan atau menggunakan pompa payudara. Namun, isapan bayi memberi rangsangan yang jauh lebih besar dibandingkan dengan kedua cara tersebut.

\section{Pengosongan Sempurna Payudara}

Sebaiknya bayi mengosongkan payudara sebelum diberikan payudara yang lain. Bila bayi tidak mengosongkan payudara yang 
kedua, maka pada pemberian ASI yang berikutnya, payudara kedua ini yang diberikan pertama kali. Jika bayi sudah kenyang dengan satu payudara, maka payudara yang kedua digunakan pada pemberian ASI berikutnya. Bila menginginkan bayi benarbenar kenyang, maka bayi perlu diberikan air susu pertama (foremilk) untuk sekali minum. Hal ini hanya dapat dicapai dengan pengosongan sempurna pada satu payudara.

Apabila air susu yang diproduksi tidak dikeluarkan, maka laktasi akan tertekan (mengalami hambatan) karena terjadi pembengkakan alveoli dan sel keranjang tidak dapat berkontraksi. ASI tidak dapat dipaksa masuk ke dalam duktus laktiferus. Rutinitas dan pola minum ASI akan terbentuk dengan sendirinya.

Produksi ASI yang rendah dapat disebabkan oleh hal-hal berikut ini:

1. Kurang sering menyusui.

2. Apabila bayi tidak bisa menghisap ASI secara efektif, bisa disebabkan :

a. Struktur mulut dan rahang yang kurang baik.

b. Teknik perlekatan yang salah.

c. Kelainan endokrin ibu (jarang terjadi).

d. Jaringan payudara hipoplastik.

e. Kelainan metabolisme atau pencernaan bayi sehingga tidak dapat mencerna ASI.

3. Kurangnya gizi ibu. 
1. Frekuensi pemberian susu.

2. Berat bayi saat lahir.

3. Usia kehamilan saat melahirkan.

4. Usia ibu dan paritas.

5. Stres dan penyakit akut.

6. Mengkonsumsi rokok.

7. Mengkonsumsi alkohol.

8. Pil kontrasepsi.

\subsection{Air Susu Ibu (ASI)}

Air Susu Ibu merupakan nutrisi alamiah terbaik bagi bayi karena mengandung kebutuhan energi dan zat yang dibutuhkan selama enam bulan pertama kehidupan bayi. Kendala utama seorang ibu dalam memberikan ASI pada bayi adalah produksi ASI yang tidak lancar.

Pada saat menyusui, sekitar 1,5 liter susu mungkin dibentuk setiap haari. Banyak zat-zat metabolik dialirkan dari ibu, misalnya \pm 50 gram lemak masuk susu setiap hari dan kira-kira 100 gram laktosa yang harus dibentuk dari glukosa hilang dari ibu setiap hari. Dua sampai tiga gram kalsium fosfat mungkin juga hilang setiap hari, dan kecuali bila ibu minum susu dalam jumlah besar dan mendapatkan masukan vitamin D yang cukup, pengeluaran kalsium dan fosfat oleh kelenjar mammae yang sedang laktasi akan jauh lebih besar daripada masukan zat-zat ini. Untuk menyuplai kalsium dan fosfat yang dibutuhkan, kelenjar paratiroid sangat membesar dan tulang secara progresif mengalami dekalsifikasi. Masalah dekalsifikasi biasanya tidak besar selama kehamilan, tetapi hal ini dapat menjadi masalah yang nyata selama laktasi.

Menurut stadium laktasi, ASI dibedakan sebagai berikut : 


\section{Kolostrum.}

Merupakan cairan viscous kental dengan warna kekuningkuningan, lebih kuning dibandingkan dengan susu yang matur. Disekresi oleh kelenjar payudara dari hari pertama sampai hari ketiga atau keempat. Komposisi dari kolostrum ini dari hari ke hari selalu berubah.

\section{Air susu masa peralihan.}

Ciri dari air susu pada masa peralihan adalah sebagai berikut :

a. Peralihan ASI dari kolostrum sampai menjadi ASI yang matur.

b. Disekresi dari hari ke-4 sampai hari ke-10 dari masa laktasi atau teori lain yang mengatakan bahwa ASI matur baru terjadi pada minggu ke-3 sampai minggu ke-5.

c. Kadar protein makin rendah, sedangkan kadar karbohidrat dan lemak makin tinggi.

d. Volumenya juga akan makin meningkat.

Tabel 6.2 Komposisi ASI menurut I.S Kleiner dan J.M Osten

\begin{tabular}{l|l|l|l}
\hline Waktu & Protein $^{*}$ & Karbohidrat $^{*}$ & Lemak $^{*}$ \\
\hline Hari ke-5 & 2,00 & 6,42 & 3,2 \\
\hline Hari ke-9 & 1,73 & 6,73 & 3,7 \\
\hline Minggu ke-34 & 1,30 & 7,11 & 4,0 \\
\hline
\end{tabular}

*dalam satuan gram/100 ml ASI

\section{Air susu matur.}

Ciri dari air susu matur adalah sebagai berikut :

a. ASI yang disekresi pada hari ke-10 dan seterusnya, komposisi relatif konstan (ada pula yang mengatakan bahwa komposisi ASI relatif konstan baru dimulai pada minggu ke-3 sampai minggu ke-5). 
b. Pada ibu yang sehat, produksi ASI untuk bayi akan tercukupi. ASI merupakan makanan satu-satunya yang paling baik dan cukup untuk bayi sampai usia 6 bulan.

c. Suatu cairan berwarna putih kekuning-kuningan yang diakibatkan warna dari garam Ca-caseinant, riboflavin dan karoten yang terdapat di dalamnya.

d. Tidak menggumpal jika dipanaskan.

e. Terdapat antimikrobial faktor.

f. Interferron producing cell.

g. Sifat biokimia yang khas, kapasitas bufer yang rendah dan adanya faktor bifidus.

\section{Beberapa jenis ASI adalah sebagai berikut :}

1. Kolostrum, diproduksi pada beberapa hari pertama. Jenis air susu ini sangat kaya protein dan antibodi serta sangat kental. Pada awal menyusui, kolostrum yang keluar mungkin hanya sesendok teh saja. Kolostrum melapisi usus bayi dan melindunginya dari bakteri.

2. Foremilk, disimpan pada saluran penyimpanan dan keluar pada awal menyusui. Dihasilkan sangat banyak dan cocok untuk menghilangkan rasa haus bayi.

3. Hindmilk, keluar setelah foremilk habis, saat menyusui hampir selesai. Jenis air susu ini sangat kaya, kental dan penuh lemak bervitamin. Mirip dengan hidangan utama setelah sup pembuka. Bayi memerlukan foremilk dan hindmilk.

\section{Beberapa kebaikan dari ASI yaitu :}

1. Steril, aman dari pencemaran kuman.

2. Selalu tersedia dengan suhu yang optimal.

3. Produksi disesuaikan dengan kebutuhan bayi.

4. Mengandung antibodi yang dapat menghambat pertumbuhan atau membunuh kuman atau virus. 
5. Bahaya alergi tidak ada.

\section{Antimikrobial faktor dalam ASI, antara lain :}

1. Antibodi terhadap bakteri dan virus.

2. Sel (fagosit granulosit dan mikrofag dan limfosit tipe T).

3. Enzim (lisozim, laktoperoksidase, lipase, katalase, fosfatase, amylase, fosfodiesterase, alkalinfosfatase).

4. Protein (laktoferin, B12 binding protein).

5. Faktor resisten terhadap strafilokokus.

6. Komplemen.

7. Interferron Producing Cell.

8. Sifat biokimia yang khas, kapasitas bufer yang rendah dan adanya faktor bifidus.

9. Hormon-hormon.

Laktoferin merupakan suatu iron binding protein yang bersifat bakteriostatik kuat terhadap Escherichia coli dan juga menghambat pertumbuhan Candida Albicans. Laktobasilus bifidus merupakan koloni kuman yang memetabolisme laktosa menjadi asam laktat yang menyebabkan rendahnya $\mathrm{pH}$ sehingga pertumbuhan kuman patogen akan dihambat.

ASI mengandung protein lebih rendah dari Air Susu Sapi, tetapi protein ASI ini mempunyai nilai nutrisi yang tinggi (lebih mudah dicerna). Rasio protein whey : kasein $=60: 40$. Hal ini menguntungkan bagi bayi karena pengendapan dari protein whey lebih halus daripada kasein sehingga protein whey lebih mudah dicerna. ASI mengandung alfa-laktalbumin, serta mengandung asam amino esensial taurin yang tinggi, yang penting untuk pertumbuhan retina dan konjugasi bilirubin.

Pada ASI juga mengandung kadar methionin dan sistin lebih tinggi bila dibandingkan dengan susu sapi sehingga sangat menguntungkan karena enzim sistionase yaitu enzim yang akan 
mengubah methionin menjadi sistin pada bayin sangat rendah atau tidak ada. Sistin ini merupakan asam amino yang sangat penting untuk pertumbuhan otak bayi. Selain protein, ASI juga mengandung karbohidrat, dan karbohidrat yang utama dalam ASI adalah laktosa yang nantinya difermentasi menjadi asam laktat. Asam laktat akan membuat suasana dalam usus bayi menjadi asam sehingga dapat memberikan keuntungan sebagai berikut :

1. Penghambatan pertumbuhan bakteri yang patologis.

2. Memacu pertumbuhan mikroorganisme yang memproduksi asam organik dan menyintesis vitamin.

3. Memudahkan terjadinya pengendapan dari Ca-caseinat.

4. Memudahkan absorpsi dari mineral, misalnya kalsium, fosfor dan magnesium.

Kadar lemak dalam ASI merupakan sumber kalori yang utama bayi, dan sumber vitamin yang larut dalam lemak (A, D, E, dan K) dan sumber asam lemak yang esensial. Keistimewaan lemak dalam ASI adalah sebagai berikut :

1. Bentuk emulsi lebih sempurna. Hal ini disebabkan ASI mengandung enzim lipase yang memecah trigliserida menjadi digliserida dan kemudian menjadi monogliserida sebelum pencernaan di usus terjadi.

2. Kadar asam lemak tak jenuh dalam ASI yang terpenting adalah sebagai berikut :

a. Rasio asam linoleik : oleik yang cukup akan memacu absorpsi lemak dan kalsium, serta adanya garam kalsium dari asam lemak akan memacu perkembangan otak bayi dan mencegah terjadinya hipokalsemia.

b. Asam lemak rantai panjang (arachidonic dan docadexaenoic) yang berperan dalam perkembangan otak.

c. Kolesterol yang diperlukan untuk mielinisasi susunan saraf pusat dan diperkirakan juga berfungsi dalam pembentukan 
enzim untuk metabolisme kolesterol yang akan mengendalikan kadar kolesterol kelak di kemudian hari.

ASI mengandung mineral yang lengkap, walau kadarnya relatif rendah, tetapi cukup untuk bayi sampai berumur 6 bulan. Jumlahnya selama laktasi adalah konstan, tetapi beberapa mineral kadarnya bergantung pada diet dan stasium laktasi. Kadar Fe dan Ca paling stabil, garam organik yang terdapat dalam ASI adalah kalsium, kalium, dan natrium dari asam klorida dan fosfat.

Kandungan air dalam ASI mencapai 88\% yang berguna untuk melarutkan zat-zat yang ada didalamnya dan akan meredakan rangsangan haus dari bayi. Vitamin $A, D$ dan $C$ cukup, sedangkan vitamin B kecuali riboflavin dan asam petothenik adalah kurang. Kalori ASI relatif rendah, hanya 77 kalori/100 ml ASI. Sekitar 90\% berasal dari karbohidrat dan lemak dan $10 \%$ berasal dari protein.

\section{Anjuran pemberian ASI adalah sebagai berikut :}

1. Usia bayi 0-6 bulan.

ASI eksklusif memenuhi 100\% kebutuhan.

2. Usia bayi 6-12 bulan.

ASI memenuhi $60-70 \%$ kebutuhan, perlu makanan pendamping ASI yang adekuat.

3. Usia > 12 bulan.

ASI hanya memenuhi $30 \%$ kebutuhan, ASI tetap diberikan untuk keuntungan lainnya.

\section{Pengaruh Waktu pada Komposisi ASI}

ASI menit pertama lebih cepat encer, kemudian akan lebih kental, ASI pada menit terakhir mengandung lemak $4-5 x$ dan protein $1,5 x$ lebih banyak dibandingkan dengan ASI menit pertama. Komposisi ASI 15 menit pertama pada saat menyusu adalah sebagai berikut :

1. 5 menit pertama mendapatkan : 

a. $60 \%$ total volume ASI.
b. $60 \%$ total protein ASI.
c. $60 \%$ total karbohidrat ASI.
d. $40 \%$ total lemak ASI.
e. $50 \%$ total energi ASI.

2. 5 menit kedua mendapatkan :
a. $25 \%$ total volume ASI.
b. $25 \%$ total protein ASI.
c. $25 \%$ total karbohidrat ASI.
d. $33 \%$ total lemak ASI.
e. $25 \%$ total energi ASI.

3. 5 menit terakhir adalah sisanya

Volume ASI akan menurun sesuai dengan waktunya, seperti berikut ini :

1. Tahun pertama $: 400-700 \mathrm{ml} / 24$ jam.

2. Tahun kedua: $200-400 \mathrm{ml} / 24 \mathrm{jam}$.

3. Sesudah itu : sekitar $200 \mathrm{ml} / 24$ jam.

\section{Pengaruh Individu terhadap Komposisi ASI}

Kenaikan jumlah paritas ada sedikit perubahan produksi walaupun tidak bermakna, yaitu sebagai berikut :
1. Anak pertama
: jumlah ASI + $580 \mathrm{ml} / 24$ jam.
2. Anak kedua
: jumlah ASI + $654 \mathrm{ml} / 24$ jam.
3. Anak ketiga : jumlah ASI + $602 \mathrm{ml} / 24$ jam.
4. Anak keempat : jumlah ASI + $600 \mathrm{ml} / 24$ jam.
5. Anak kelima : jumlah ASI + $506 \mathrm{ml} / 24$ jam.
6. Anak keenam : jumlah ASI + $524 \mathrm{ml} / 24$ jam.

Beberapa manfaat dari menyusui adalah sebagai berikut :

1. Manfaat bagi bayi.

a. Komposisi sesuai kebutuhan. 
b. Kalori dari ASI memenuhi kebutuhan bayi sampai usia enam bulan.

c. ASI mengandung zat pelindung.

d. Perkembangan psikomotorik lebih cepat.

e. Menunjang perkembangan penglihatan.

f. Memperkuat ikatan batin antara ibu dan anak.

g. Dasar untuk perkembangan emosi yang hangat.

h. Dasar untuk perkembangan kepribadian yang percaya diri.

\section{Manfaat bagi ibu.}

a. Mencegah perdarahan pascapersalinan dan mempercepat kembalinya rahim ke bentuk semula.

b. Mencegah anemia defisiensi zat besi.

c. Mempercepat ibu kembali ke berat badan sebelum hamil.

d. Menunda kesuburan.

e. Menimbulkan perasaan dibutuhkan.

f. Mengurangi kemungkinan kanker payudara dan ovarium. 


\section{BAB 7}

\section{PERKEMBANGAN DAN PERSIAPAN KEHIDUPAN NEONATUS DARI INTRA KE EKSTRA-UTERUS}

Pada proses persalinan, beberapa saat setelah lahir janin yang keriput dan basah berupa menjadi bayi yang hidup bebas. Keadaan fisiologis yang berkaitan dengan kelahiran bayi adalah beralihnya alat pertukaran udara dari plasenta ke paru dan pergantian sistem sirkulasi janin ke sirkulasi dewasa yang sangat dibutuhkan. Bayi mulai bernafas dan menangis segera setelah lahir, keadaan ini menunjukkan terbentuknya respirasi aktif. Suhu bayi turun dengan cepat segera setelah lahir.

Pembicaraan perkembangan fetus dan fungsi organ bayi dimulai segera setelah hadir. Pertumbuhan dan perkembangan sepanjang tahun pertama kehidupan merupakan bagian dari pembahasan bab ini. Fokus pembahasan lebih diarahkan pada kajian fisiologis, di mana perkembangan awal dari plasenta dan membran fetus terjadi jauh lebih cepat dari perkembangan fetus itu sendiri. Selama 2-3 minggu pertama ukuran fetus hampir tetap ukuran mikroskopis. Akan tetapi, ukuran fetus akan meningkat 
seiring dengan pertambahan usianya. Pada 12 minggu pertama, panjang fetus sekitar $10 \mathrm{~cm}$; 20 minggu, kira-kira $25 \mathrm{~cm}$ dan 40 minggu, sekitar $50 \mathrm{~cm}$.

Berat fetus sebanding dengan pangkat 3 usia fetus. Oleh karena itu, penambahan berat fetus hampir tidak ada selama bulan-bulan pertama dan hanya mencapai 1 pon pada 5 setengah bulan kehamilan. Selama trimester ke-3 kehamilan, pertambahan berat fetus hingga 2 bulan sebelum persalinan adalah 1 bulan sebelum persalinan sekitar 4,5 pon dan pada saaat persalinan sekitar 7 pon. Berat badan waktu lahir bervariasi dari 4,5 pon sampai 11 pon.

\section{Kebutuhan Kalsium}

Neonatus baru saja dimulai mengadakan osifikasi tulang yang cepat pada waktu lahir sehingga ia membutuhkan suplai kalsium yang tersedia selama masa bayi.

\section{Kebutuhan Besi}

Jika ibu mendapatkan besi yang adekuat dalam makanannya, hati bayi biasanya menyimpan cukup besi untuk tetap membentuk selsel darah selama empat sampai enam bulan setelah lahir. Akan tetapi, jika ibu kekurangan besi dalam makanannya, anemia mungkin akan dialami bayi setelah kira-kira berumur tiga bulan. Oleh karena itu, sebaiknya diberikan pemberian besi dalam beberapa bentuk lainnya menjelang bulan kedua atau ketiga kehidupan.

\section{Vitamin C}

Asam askorbat (vitamin C) tidak disimpan dalam jumlah bermakna di dalam jaringan fetus, meskipun vitamin ini diperlukan untuk pembentukan tulang rawan, tulang, dan struktur intersel lain pada 
bayi. Oleh karena itu, sari jeruk atau sumber-sumber asam askorbat lain biasanya diberikan menjelang minggu ketiga kehidupan.

Ginjal fetus mampu menyekresikan selama paling sedikiy kehamilan terakhir. Sistem pengaturan ginjal untuk mengatur keseimbangan asam basa belum terjadi selama setengah kehamilan. Bahkan belum mencapai perkembangan sempurna sampai sebulan terakhir lahir.

\subsection{PERKEMBANGAN SISTEM ORGAN FETUS}

Sekitar 1 bulan setelah fertilisasi ovum, semua organ fetus telah terbentuk sebagian (minimal) dan selama dua tiga bulan berikutnya organ telah terbentuk. Selanjutnya, setelah bulan keempat organ-organ fetus sama dengan organ neonatus. Perkembangan struktur organ yang lebih kecil (struktur sel) lebih baik dan memerlukan lima bulan kehamilan sisanya untuk menyempurnakan perkembangan. Bahkan ketika lahir, beberapa struktur tertentu (sistem saraf, ginjal, dan hati) belum sempurna.

\section{Sistem Pernapasan}

Pergerakan pernapasan berlangsung mulai pada akhir trimester pertama kehamilan di mana kehadiran alveoli mulai minggu ke-25 kehamilan, dan diisi dengan cairan paru-paru. Pergerakan pernapasan sekejap tidak ada pada fetus pertukaran gas berlaku antara tubuh janin dan plasenta.

Paru-paru berasal dari titik tumbuh yang muncul dari faring yang bercabang, kemudian bercabang kembali membentuk struktur percabangan bronkus. Proses ini berlanjut setelah kelahiran sampai usia sekitar delapan tahun hingga jumlah bronkiolus dan alveolus akan sepenuhnya berkembang, meskipun gerakan napas janin mulai terlihat mulai trimester kedua dan ketiga. 
Pengaruh kelahiran yang paling nyata pada bayi adalah putusnya hubungan plasenta dengan ibu dan terhentinya cara untuk mendukung metabolisme. Hal yang paling penting adalah terhentinya suplai oksigen dan ekskresi O2 plasenta. Penyesuaian plasenta yang pertama diperlukan bayi adalah mulainya pernapasan.

Biasanya anak mulai bernapas segera dan mempunyai irama pernapasan yang normal. Kecepatan fetus mulai bernapas menunjukkan bahwa bernapas dimulai oleh terpaparnya bayi secara mendadak ke dunia luar, mungkin akibat dari keadaan asfiksia ringan karena proses kelahiran, tetapi juga akibat implus sensori yang berasal dari kulit yang mendadak dingin.

Upaya pernapasan pertama seorang bayi berfungsi untuk mengeluarkan cairan dalam paru-paru matang pada minggu ke-30 sampai minggu ke-40 kehamilan. Surfaktan berfungsi mengurangi tekanan permukaan paru-paru dan membantu menstabilkan dinding alveolus sehingga tidak kolaps pada akhir pernapasan. Tanpa surfaktan, alveoli akan kolaps setiap saat setelah akhir pernapasan sehingga dapat menyebabkan sulit bernapas.

Ketika lahir, dinding alveoli disatukan oleh tegangan permukaan cairan kental yang melapisinya. Diperlukan lebih dari $25 \mathrm{mmHg}$ ke tekanan negatif untuk melawan pengaruh tegangan permukaan tersebut dan untuk membuka alveoli pertama kalinya. Sekali alveoli terbuka, pernapasan tersebut dapat dilakukan oleh pergerakan pernapasan yang relatif lemah. Infrinasi baru lahir sangat kuat, biasanya mampu menimbulkan tekanan negatif sebesar $50 \mathrm{mmHg}$ dalam ruangan intrapleura. Frekuensi napas bayi yang normal 40-60 kali/menit yang cenderung dangkal dan jika bayi tidak sedang tidur, kecepatan irama dan kedalamannya tidak teratur. 
Bayi cukup bulan mempunyai cairan di dalam paru. Pada waktu persalinan, sekitar $1 / 3$ cairan diperas keluar paru. Dengan beberapa kali tarikan napas pertama, udara memenuhi ruangan trakea dan brokus bayi baru lahir. Dengan sisa cairan di dalam paru dikeluarkan dari paru dan diserap oleh pembuluh limfe darah.

\section{Dua faktor yang berperan pada perangsangan napas pertama} bayi baru lahir adalah sebagai berikut :

1. Hipoksia pada akhir persalinan dan rangsangan fisik lingkungan luar rahim akan merangsang pusat pernapasan di otak.

2. Tekanan terhadap rongga dada yang terjadi karena kompresi paru-paru selama persalinan akan merangsang masuknya udara ke dalam paru-paru secara mekanis.

\section{Fungsi Pernapasan dalam Kaitannya dengan Fungsi Kardiovaskular}

Oksigenasi sangat penting dalam mempertahankan kecukupan pertukaran udara. Jika terjadi hipoksia, pembuluh darah paru-paru akan mengalami vasokontriksi. Keadaan ini berarti tidak ada pembuluh darah yang terbuka untuk menerima oksigen yang berada dalam alveoli sehingga terjadi penurunan oksigenasi jaringan yang akan memperburuk hipoksia. Peningkatan aliran darah paru-paru akan memperlancar pertukaran gas dalam alveolus dan menghilangkan cairan paru-paru sehingga akan mendorong terjadinya peningkatan sirkulasi limfe dan membantu menghilangkan cairan paru-paru serta merangsang perubahan sirkulasi janin menjadi sirkulasi luar rahim.

\section{Sistem Sirkulasi}

Penyesuaian sirkulasi segera yang memungkinkan aliran darah yang adekuat melalui paru-paru adalah salah satu faktor penting 
selain mulainya pernapasan ketika lahir. Oleh karena paru tidak berfungsi terutama selama kehidupan fetal, maka jantung fetus tidak perlu memompa darah dalam jumlah besar melalui plasenta.

Sebagian besar darah yang masuk ke atrium kanan dari vena kava inferior langsung berjalan lurus melalui permukaan posterior atrium kanan dan kemudian melalui foramen ovale langsung masuk ke dalam atrium kiri. Jadi darah yang dioksigenasi baik dari plasenta masuk ke sisi kiri jantung bukan ke sisi kanan jantung dan dipompa oleh ventrikel kiri terutama ke dalam pembuluh darah kepala dan anggota gerak bawah.

Darah yang masuk atrium kanan dari vena kava superior langsung berjalan turun melalui katup trikuspidalis masuk ke dalam ventrikel kanan. Darah ini terutama darah deoksigenisasi dari daerah kepala fetus, dan di pompa oleh ventrikel kanan masuk ke dalam arteria pulmonalis, kemudian terutama melalui duktus arteriosus masuk ke dalam aorta desenden dan melalui arteria umbilikalis masuk ke plasenta, tempat darah deoksigenisasi mengalami oksigenisasi.

\section{Sistem Sirkulasi dan Hematologi}

Aliran darah fetal bermula dari vena umbilikalis, akibat tahanan pembuluh paru yang besar (lebih tinggi dibanding tahanan vaskular sistemik / SVR) hanya $10 \%$ dari keluaran ventrikel kanan yang sampai paru, sedangkan sisanya $90 \%$ terjadi shunting kanan ke kiri melalui duktus arteriosus Bottali.

Pada waktu bayi lahir, terjadi pelepasan dari plasenta secara mendadak (saat umbilical cord dipotong/dijepit), tekanan atrium kanan menjadi rendah, tahanan pembuluh darah sistemik (SVR) naik dan pada saat yang sama paru mengembang, tahanan vaskular paru menyebabkan penutupan foramen ovale (menutup setelah beberapa minggu), aliran darah di duktus arteriosus Bottali terbalik dari kiri ke kanan. Kejadian ini disebut sirkulasi transisi. 
Penutupan duktus arteriosus secara fisiologis terjadi pada umur bayi 10-15 jam yang disebabkan kontraksi otot polos pada akhir arteri pulmonalis dan secara anatomis pada usia 2-3 minggu.

Pada neonatus, reaksi pembuluh darah masih sangat kurang sehingga keadaan kehilangan darah, dehidrasi dan kelebihan volume juga sangat kurang untuk ditoleransi. Manajemen cairan pada neonatus harus dilakukan dengan cermat dan teliti. Tekanan sistolik merupakan indikator yang baik untuk menilai sirkulasi volume darah dan dipergunakan sebagai parameter yang adekuat terhadap penggantian volume. Otoregulasi aliran darah otak pada bayi baru lahir tetap terpelihara normal pada tekanan sistemik antara $60-130 \mathrm{mmHg}$. Frekuensi nadi bayi rata-rata $120 \mathrm{kali} / \mathrm{menit}$ dengan tekanan darah sekitar $80 / 60 \mathrm{mmHg}$.

\section{Perubahan pada Sistem Peredaran darah}

Setelah lahir, darah bayi baru lahir harus melewati paru untuk mengambil oksigen dan mengadakan sirkulasi melalui tubuh guna mengantarkan oksigen ke jaringan. Untuk membuat sirkulasi yang baik, kehidupan di luar rahim harus terjadi dua perubahan besar, yaitu sebagai berikut :

1. Penutupan foramen ovale pada atrium jantung.

2. Perubahan duktus arteriousus antara paru=paru dan aorta.

Perubahan sirkulasi ini terjadi akibat perubahan tekanan pada seluruh sistem pembuluh. Oksigen menyebabkan sistem pembuluh mengubah tekanan dengan cara mengurangi/ meningkatjan resistensinya sehingga mengubah aliran darah.

Dua peristiwa yang mengubah tekanan dalam sistem pembuluh darah adalah sebagai berikut : 
1. Pada saat tali pusat dipotong resistensi pembuluh sistemik meningkat dan tekanan atrium kanan menurun, tekanan atrium menurun karena berkurangnya aliran darah ke atrium kanan tersebut. Hal ini menyebabkan penurunan volume dan tekanan atrium kanan itu sendiri. Kedua kejadian ini membantu darah dengan kandungan oksigen sedikit mengalir ke paru-paru untuk menjalani proses oksigenasi ulang.

2. Pernapasan pertama menurunkan resistensi pada pembuluh darah paru-paru dan meningkatkan tekanan pada atrium kanan. Oksigen pada pernapasan ini menimbulkan relaksasi dan terbukanya sistem pembuluh darah paru. Peningkatan sirkulasi ke paru-paru mengakibatkan peningkatan volume darah dan tekanan pada atrium kanan, sehingga terjadi penurunan tekanan pada atrium kiri, foramen kanan dan penusuran pada atrium kiri, serta kanan yang menyebabkan foramen ovale secara fungsional akan menutup. Vena umbilikus, duktus venosus, dan arteri hipogastrika dari tali pusat menutup secara fungsional dalam beberapa menit setelah lahir dan setelah tali pusat di klem. Penutupan anatomi jaringan fibrosa berlangsung 2-3 bulan.

\section{Perbedaan Sirkulasi Darah Fetus dan Bayi.}

\section{Sirkulasi Darah Fetus.}

1. Struktur tambahan pada sirkulasi fetus.

a. Vena umbilikalis.

Membawa darah yang telah mengalami deoksigenasi dari plasenta ke permukaan dalam hepar.

b. Duktus venosus.

Meninggalkan vena umbilikalis sebelum mencapai hepar dan mengalirkan sebagian besar darah baru yang mengalami oksigenasi ke dalam vena cava inferior.

c. Foramen ovale. 
Merupakan lubang yang memungkinkan darah lewat atrium dekstra ke dalam ventrikulus sinistra.

d. Duktus arteriosus.

Merupakan bypass yang terbentang dari ventrikulus dekstra dan aorta desendens.

e. Arteri hipogastrika.

Dua pembuluh darah yang mengembalikan darah dari fetus ke plasenta. Pada feniculus umbilikalis, arteri ini dikenal sebagai arteri umbilikalis. Pada bagian dalam tubuh fetus, arteri tersebut dikenal sebagai arteri hipogastrika.

2. Sistem sirkulasi fetus.

a. Vena umbilikalis.

Membawa darah yang kaya oksigen dari plasenta ke permukaan dalam hepar. Vena hepatika meninggalkan hepar dan mengembalikan darah ke vena cava inferior.

b. Duktus venosus.

Merupakan cabang-cabang dari vena umbilikalis dan mengalirkan sejumlah besar darah yang mengalami oksigenasi ke dalam vena cava.

c. Vena cava inferior.

Mengalirkan darah yang telah beredar dalam ekstremitas inferior dan badan fetus, menerima darah dari vena hepatika dan duktus venosus, serta membawanya ke atrium dekstra.

d. Foramen ovale.

Memungkinkan lewatnya sebagian besar darah yang mengalami oksigenasi dalam ventrikel dekstra menuju ke atrium sinistra. Selanjutnya, dari atrium sinistra, darah melewati valvula mitralis ke ventrikel sinistra dan kemudian melalui aorta masuk ke dalam cabang asendennya untuk 
memasok darah bagi kepala dan ekstremitas superior. Dengan demikian hepar, jantung dan serebrum menerima darah baru yang mengalami oksigenasi.

e. Vena cava superior.

Mengembalikan darah dari kepala dan ekstremitas superior ke atrium dekstra. Darah ini bersama sisa aliran yang dibawa oleh vena cava inferior melewati valvula trikupidallis masuk ke dalam ventrikel dekstra.

f. Arteria pulmonalis.

Mengalirkan darah campuran ke paru-paru yang nonfungsional, di mana hanya memerlukan nutrien sedikit.

g. Duktus arteriosus.

Mengalirkan sebagian besar darah dari vena ventrikel dekstra ke dalam aorta desenden untuk memasok darah bagi abdomen, pelvis, dan ekstremitas inferior.

h. Arteri hipogastrika.

Merupakan lanjutan dari arteri iliaka interna, membawa darah kembali ke plasenta dengan mengandung lebih banyak oksigen dan nutrien yang dipasok dari peredaran darah maternal.

\section{Perubahan yang terjadi pada bayi saat lahir adalah sebagai berikut :}

1. Penghentian pasokan darah dari plasenta.

2. Pengembangan dan pengisian udara dari paru-paru.

3. Penutupan foramen ovale.

4. Fibrosis :

a. Vena umbilikalis.

b. Duktus venosus.

c. Arteri hipogastrika.

d. Duktus arteriosus. 
Sirkulasi pulmonari : vena umbilikus, duktus venosus, foramen ovale, dan duktus arteriosus.

\section{Sirkulasi Fetus}

1. Rintangan tinggi pada sirkulasi pulmonal.

2. Rintangan rendah pada sirkulasi sistemik.

Terjadinya pergerakan darah dari sebelah kanan ke kiri :

1. Foramen ovale.

Tekanan arteri sebelah kiri rendah karena darah yang kembali ke paru-paru adalah rendah dan tingginya tekanan pada arteri sebelah kanan karena isi pada darah dari plasenta tinggi.

2. Duktus arteriosus.

Rintangan tinggi pada sirkulasi pulmonari. Rintangan (resisten) rendah pada sirkulasi sistemik fetus dan fungsi prostaglandin.

\section{Sirkulasi Neonatal}

1. Banyak perubahan dalam sirkulasi ketika kelahiran. Bertambahnya aliran darah pada sirkulasi pulmonal terjadi akibat turunnya resisten pada sirkulasi pulmonal sehingga paru-paru mengembang.

2. Darah vena kembali daripada jantung meningkat.

3. Tekanan arteri kiri meningkat, sedangkan arteri kanan berkurang mengakibatkan foramen ovale tertutup.

4. Resisten sirkulasi sistemik lebih tinggi daripada resisten pulmonal dalam masa 24 jam. Fungsi prostaglandin menyebabkan duktus arteriosus menutup.

5. Arteri-arteri umbilikus mengerut dan aliran darah ke plasenta berhenti.

\section{Perbedaan sirkulasi fetus dan sirkulasi neonatal.}




\begin{tabular}{l|l|l|l}
\hline No & Perbedaan & Sirkulasi Fetus & Sirkulasi Neonatal \\
\hline 1. & Sirkulasi pulmonal & $\begin{array}{l}\text { Aktif, kurang } \\
\text { berkembang }\end{array}$ & $\begin{array}{l}\text { Aktif, perkembangan } \\
\text { meningkat }\end{array}$ \\
\hline 2. & Foramen ovale & Terbuka & Tertutup \\
\hline 3. & $\begin{array}{l}\text { Duktus arteriosus } \\
\text { botali }\end{array}$ & Terbuka & Tertutup \\
\hline 4. & $\begin{array}{l}\text { Duktus venosus } \\
\text { arantii }\end{array}$ & Terbuka & Tertutup \\
\hline 5. & Sirkulasi sistemik & $\begin{array}{l}\text { Aktif dengan } \\
\text { resisten rendah }\end{array}$ & $\begin{array}{l}\text { Aktif dengan } \\
\text { meningkatnya } \\
\text { resisten }\end{array}$ \\
\hline
\end{tabular}

\section{Perubahan sirkulasi fetal waktu lahir :}

1. Hilangnya aliran darah dalam jumlah besar melalui plasenta.

Sebenarnya hal ini meningkatkan tekanan aorta serta tekanan atrium kiri.

2. Tahapan vaskular paru sangat menurun.

Sebagai akibat dari pengembangan paru-paru. Pada fetus yang tidak mengembang, pembuluh darah tertekan karena volume paru yang kecil. Segera setelah mengembang, pembuluh darah tersebut tidak lagi tertekan dan tahanan terhadap aliran darah berkurang.

3. Penutupan foramen ovale.

Tekanan atrium kanan yang rendah dan tekanan atrium kiri yang tinggi, secara sekunder akan berpengaruh terhadap perubahan tahanan paru dan sistem waktu lahir sehingga menyebabkan kecenderungan darah mengalirkan balik dari atrium kiri ke atrium kanan bukan sebaliknya, seperti yang terjadi dalam kehidupan fetal. Akibatnya katup kecil yang terletak di atas foramen ovale pada sisi kiri septum atrium menutup lubang tersebut karena hal tersebut dapat mencegah aliran lebih lanjut.

4. Penutupan duktus arteriosus. 
Efek yang sama terjadi dalam hubungannya dengan duktus arteriosus karena meningkatkan tahanan pada paru dan mengurangi tahanan pada arteri pulmonalis. Sebagai akibatnya, segera setelah lahir, darah mulai mengalir balik dari aorta ke arteri pulmonalis bukan dengan arah sebaliknya dari aorta seperti kehidupan fetal. Akan tetapi, hanya setelah beberapa jam dinding otot duktus arteriosus mengadakan kontraksi nyata, dan dalam 8 hari kontraksi cukup untuk menghentikan aliran darah. Hal ini dinamakan penutupan fungsional duktus arteriosus. Kemudian, terkadang selama bulan ke-2 kehidupan, biasanya duktus arteriosus tertutup secara anatomi oleh pertumbuhan jaringan fibrosa.

\section{Pembentukan Sel-sel darah}

1. Sel-sel darah berinti mulai pada kantung kuning telur dan lapisan mesotel plasenta sekitar minggu ke-3 perkembangan fetus. Satu minggu kemudian diikuti pembentukan sel-sel darah merah oleh mesenkim dan endotel pembuluh darah fetus.

2. Minggu ke-6, hati mulai membentuk sel darah.

3. Pada bulan ke-3 limpa dan jaringan limfoid tubuh mulai membentuk sel-sel darah merah.

4. Pada bulan ke-3 dan seterusnya sumsum tulang mulai semakin mulai membentuk sel-sel darah merah dan putih. Sementara itu, struktur-struktur lain kehilangan kemampuannya sama sekali untuk membentuk sel-sel darah.

\section{Traktus Digestivus}


Pada umumnya kemampuan neonatus mencerna, mengabsorpsi, dan memetabolisme makanan tidak berbeda dari anak-anak. Namun, ada tiga pengecualian yaitu sebagai berikut :

1. Sekresi amilase pankreas pada neonatus tidak mencukupi sehingga bayi menggunakan hati kurang adekuat daripada anak-anak. Namun, bayi mudah mengasimilasi disakarida dan monosakarida.

2. Absorpsi lemak dari saluran pencernaan sedikit kurang daripada anak-anak. Akibatnya, penggunaan susu dengan kadar lemak tinggi seperti susu sapi sering tidak adekuat.

3. Oleh karena fungsi hati selama paling sedikit seminggu pertama kehidupan tidak sempurna, konsentrasi glukosa dalam darah tidak stabil dan sering rendah.

Untuk menjalankan fungsinya, otak memerlukan glukosa dalam jumlah tertentu. Dengan tindakan penjepitan tali pusat dengan klem pada saat lahir, bayi harus mulai mempertahankan kadar glukosa darahnya sendiri. Pada setiap bayi lahir, glukosa darah akan turun dalam waktu cepat (1-2 jam).

Tiga cara koreksi penurunan gula darah adalah sebagai berikut :

1. Melalui penggunaan ASI (bayi baru lahir sehat harus didorong untuk menyusu agar ASI cepat keluar).

2. Melalui penggunaan cadangan glikogen.

3. Melalui pembuatan glukosa dari sumber lain terutama lemak (glukoneogenesis).

Neonatal yang tidak mampu mencerna makanan dalam jumlah cukup akan menciptakan glukosa dari glikogen. Glikogenesis hanya dapat terjadi jika bayi mempunyai cadangan glikogen yang cukup. Kemampuan bayi baru lahir cukup bulan untuk menelan dan mencerna makanan (selain susu) masih terbatas. Kapasitas 
lambung sendiri sangat terbatas, yaitu kurang dari 30 cc. Kapasitas lambung ini akan meningkat secara lambat bersamaan dengan tumbuhnya bayi baru lahir.

Pada pertengahan kehamilan, fetus mencernakan dan mengabsorpsi cairan amnion dalam jumlah besar selama 2-3 bulan kemudian, saluran pencernaan mencapai fungsi seperti neonatus normal.

\section{Kelenjar Endokrin}

Pematangan janin dan kelangsungan hidup neonatus diatur oleh berbagai jenis hormon. Hal ini bertujuan agar seorang bayi dapat bertahan hidup baik di dalam rahim maupun di luar rahim. Salah satu hormon yang berperan adalah hormon-hormon yang dihasilkan dari kelenjar endokrin.

Kelenjar endokrin adalah kelenjar tanpa saluran atau kelenjar buntu sebab sekresi yang dibuat tidak meninggalkan kelenjarnya melalui suatu saluran, tapi langsung masuk ke dalam darah yang beredar di dalam jaringan kelenjar. Kelenjar dari sistem endokrin menghasilkan bahan-bahan kimia yang mempengaruhi seluruh tubuh. Selama masa kehamilan, banyak perubahan yang terjadi pada kelenjar ini. Tidak hanya perubahan pada masa kehamilan, tetapi perubahan ketika bayi sudah lahir.

\section{Kelenjar-kelenjar endokrin dalam sistem endokrin neonatus adalah sebagai berikut : \\ Hipofisis Anterior}

Mulchahey dan kawan-kawan dalam suatu tinjauan tentang ontogenesis fungsi dan regulasi kelenjar hipofisis janin, mengetangahkan suatu pandangan, yaitu pertama, bahwa pengendalian sekresi hipofisis anterior janin tergantung pada pematangan sistem saraf pusat; kedua, bahwa sistem endokrin janin berfungsi selama beberapa waktu sebelum sistem saraf 
pusat melengkapi sinaptogenesisnya dan sistem-sistem integratif lainnya telah mencapai status maturitas sehingga mampu melaksanakan banyak tugas yang berkaitan dengan homeostasis; ketiga, bahwa sistem endokrin janin tidak perlu menyerupai sistem endokrin dewasa, tetapi dapat merupakan satu dari sistem homeostasik pertama kali yang dikembangkan.

Hipofisis anterior janin berdiferensiasi menjadi lima tipe sel, yang menyekresi enam hormon protein, yaitu sebagai berikut :

1. Laktotrop, memproduksi prolaktin (PRL).

2. Somatotrop, memproduksi hormon pertumbuhan (GH).

3. Kortikotrop, memproduksi kortikotropin (ACTH).

4. Tirotrop, memproduksi Thyroid Stimulating Hormone (TSH).

5. Gonadotrop, memproduksi Luteinizing Hormone (LH).

6. Follicle Stimulating Hormone (FSH).

\section{Neurohipofisis}

Neurohipofisis janin berkembang dengan baik pada kehamilan 10 sampai 12 minggu dan sudah dapat ditemukan oksitosin dan arginin vasopresin (AVP). Disamping itu, hormon vasotosin (AVT) terdapat di hipofisis janin dan kelenjar pineal.

Ada kemungkinan oksitosin dan AVP berfungsi pada janin untuk menghemat air, tetapi aksi-aksi ini sebagian besar pada tingkat paru dan plasenta dibandingkan pada tingkat ginjal. Pembentukan PGE2 di dalam ginjal janin dapat melemahkan kerja AVP di organ ini.

Beberapa peneliti telah menemukan bahwa kadar AVP di plasma tali pusat meningkat secara menyolok dibandingkan dengan kadar yang ditemukan dalam plasma ibu. Di samping itu, AVP dalam darah tali pusat dan darah janin tampak meninggi pada stres janin.

\section{Hipofisis Intermedia Janin}


Ada lobus intermedia hipofisis yang berkembang baik pada janin manusia. Sel-sel dalam struktur ini mulai menghilang sebelum cukup bulan dan tidak ada lagi pada hipofise dewasa. Produk sekresi utaria dari sel-sel lobus intermedia adalah hormon stimulasi $\alpha$-melanosit $(\alpha-\mathrm{MSH})$ dan $\beta$-endorfin. Kadar $\alpha-\mathrm{MSH}$ janin menurun secara progesif sesuai dengan umur kehamilan.

\section{Tiroid}

Sistem hipofisis-tiroid mampu berfungsi pada akhir trimester pertama. Akan tetapi, sampai pertengahan kehamilan, sekresi TSH dan hormon tiroid masih rendah. Ada peningkatan yang besar setelah usia ini. Mungkin sangat sedikit tirotropin melintasi plasenta dari ibu ke janin. Tiroid berjangka panjang LATS dan LATSprotektor demikian juga bila terdapat dalam konsentrasi tinggi pada ibunya. Selain itu, antibodi-antibodi IgG ibu terhadap TSH juga dapat melintasi plasenta sehingga mengakibatkan kadar TSH tinggi palsu pada neonatus.

Plasenta manusia secara aktif mengonsentrasikan yodida pada sisi janin sepanjang trimester kedua dan ketiga kehamilan. Tiroid janin mengonsentrasikan yodida lebih kuat daripada tiroid ibu. Oleh karena itu, pemberian raip-yodida atau jumlah yodida yang lebih banyak dari biasa, jelas berbahaya bagi janin.

Hormon tiroid yang berasal dari ibu melintasi plasenta pada tingkat yang sangat terbatas dengan triyodotironin lebih mudah lewat daripada tiroksin. Ada aksi terbatas hormon tiroid selama kehidupan janin. Janin manusia yang tidak memiliki tiroid tumbuh secara normal pada waktu lahir. Hanya jaringan-jaringan tertentu yang mungkin responsif terhadap hormon tiroid, yaitu otak dan paru.

\section{Kelenjar Paratiroid}


Ada bukti yang baik bahwa paratiroid menguraikan parathormon pada akhir trimester pertama dan kelenjar tersebut tampaknya memberi respons ini utero terhadap stimulasi pengaturan. Neonatus dari ibu-ibu dengan hiperparatiroidisme dapat menderita tetani hipokalsemik. Kadar kalsium plasma dalam janin, 11 sampai $12 \mathrm{mg}$ per dL, dipertahankan oleh transpor aktif dari darah ibu. Kadar paratiroid dalam darah janin relatif rendah dan kadar kalsitonin tinggi. Pada biri-biri, paratiroidektomi janin menyebabkan turunnya konsentrasi kalsium plasma janin. Nefrektomi juga menyebabkan turunnya kalsium dan $1 \alpha-$ hidroksilasi dari 25-OH-kolekalsiferol terjadi di ginjal janin.

\section{Kelenjar Adrenal}

Adrenal janin manusia bila dibanding dengan ukuran badan totalnya jauh lebih besar daripada perbandingan ukuran tersebut pada orang dewasa. Seluruh pembesaran tersebut terdapat pada bagian dalamnya atau yang disebut zona janin korteks adrenal. Zona janin yang normalnya mengalami hipertrofi tersebut, mengalami involusio dengan cepat setelah lahir. Zona janin tersebut tidak ada dalam kejadian yang jarang, dimana hipofisis janin secara kongenital tidak ada.

Adrenal janin juga menyintesis aldosteron. Pada satu penelitian, kadar aldosteron di plasma tali pusat mendekati cukup bulan, melebihi kadarnya di plasma ibu, seperti juga renin dan substrat renin. Tubulus-tubulus ginjal bayi baru lahir dan mungkin juga janin tampak relatif tidak sensitif terhadap aldosteron.

Pada awal kehidupan embrional, adrenal janin tersusun dari sel-sel yang mirip dengan sel-sel zona fetal korteks adrenal janin. Sel-sel ini dengan cepat muncul dan berproliferasi sebelum waktu vaskularisasi hipofisis oleh hipotalamus sempurna. Hal ini memberi kesan bahwa perkembangan awal adrenal janin berada di bawah pengaruh-pengaruh trofik yang mungkin tidak 
sepenuhnya sesuai dengan pengaruh trofik pada orang dewasa. Kemungkinan, ACTH disekresi oleh hipofisis janin tanpa adanya faktor corticotropin-releasing factor (CRF) atau ACTH (atau CRF) lain yang timbul dari suatu sumber selain hipofisis janin, misalnya dari ACTH (atau CRF) korionik yang disintesis oleh trofoblas. ACTH tidak meyeberangi plasenta, tetapi ada kemungkinan lain, yaitu hal ini mencakup kemungkinan bahwa ada suatu agen selain ACTH yang meningkatkan replikasi sel-sel adrenal zona fetal.

Korteks adrenal fetus normal terus-menerus berkembang sepanjang kehamilan dan selama 5 sampai 6 minggu kehamilan terakhir terjadi kenaikan dengan cepat mendekati ukuran adrenal fetus manusia. Hal ini jelas bahwa laju pertumbuhan adrenal fetus dan sekresi steroid tidak dikendalikan oleg rangsang trofik tunggal $(\mathrm{ACTH})$, tetapi lebih diatur oleh lebih dari satu jenis agen yang menunjang pertumbuhan.

\section{Gonad}

Siiteri dan Wilson (1974) mendemonstrasikan sintesis testosteron oleh testis janin dari progesteron dan pregnenolon pada kehamilan 10 minggu. Lebih lanjut, Leinonen dan Jaffe (1985) menemukan bahwa sel-sel Leydig testis janin luput dari desensitisasi yang khas pada testis dewasa, yang diberi tantangan berupa sentivitas oleh hormon hCG secara berulang.

Fenomena dalam testis janin ini mungkin disebabkan oleh halhal sebagai berikut :

1. Tidak adanya reseptor estrogen di dalam testis janin.

2. Stimulasi prolaktin pada reseptor-reseptor hCG/Lh pada testis janin.

Sel-sel leydig dalam testis janin dan kadar hCG, pembentukan testosteron testis dan kadar hCG, konsentrasi reseptor untuk kadar LH/hCG dan tidak adanya regulasi penurunan reseptor 
LH/hCG, serta ekresi testosteron testikuler janin yang terus menerus pada waktu kadar hCG tinggi. Pembentukan estrogen di ovarium janin telah didemonstrasikan, tetapi pembentukan estrogen di ovarium tidak diperlukan untuk perkembangan fenotip perempuan.

Plasenta juga memproduksi adrenokortikotropin (ACTH) korionik dan produk-produk lain dari pro-opiomelanokortik, human korionik tirotropin (hCT), dan juga hypothalamic-like releasing dan inhibiting hormon, yaitu Thyrotropin-Releasing Hormone (TRH), Gonadotropin-Releasing Hormone (GnRH) atau Luteinizing Hormon-Releasing Hormone (LHRH), CorticotropinReleasing Factor (CRF) dan somatostatin, serta inhibin dan berbagai macam protein yang unik untuk kehamilan (spesifikkehamilan) atau proses-proses neoplastik.

Beberapa hormon-hormon protein plasenta adalah sebagai berikut:

1. Gonadotropin korionik.

2. Adrenokortikotropin dan tirotropin korionik.

3. Hormon-hormon hypothalamic like-releasing dari plasenta.

4. Inhibin.

\section{SISTEM SARAF}

\section{Pembentukan sistem saraf pada janin.}

Embrio akan terus membesar sehingga pada minggu ke-5 terdapat 3 lapisan yaitu ektoderm, mesoderm, dan endoderm. Ektoderm adalah lapisan yang paling atas dan akan membentuk sistem saraf pada janin tersebut yang seterusnya membentuk otak, tulang belakang, kulit serta rambut. Neurulasi adalah pembentukan lempeng neural (neural plate) dan lipatan neural (neural folds). Penutupan lipatan ini untuk membentuk neural tube, yang 
terbenam dalam dinding tubuh dan berdiferensiasi menjadi otak dan korda spinalis.

Pada mulanya, tabung ini menutup pada tempat di mana akan terjadi pertemuan antara otak dan medula spinalis sehingga kedua ujungnya menjadi terbuka. Pada saat tersebut, embrio melipat pada sumbu panjangnya sendiri dan membentuk lipatan kepala pada tabung neural di tempat pertemuan ini. Ujung kranial tabung neural menutup, diikuti penutupan tabung kaudalnya. Selama minggu kelima, tingkat pertumbuhan yang berbeda menimbulkan banyak lekukan pada tabung neural sehingga dihasilkan tiga daerah otak yaitu otak depan, otak tengah dan otak belakang. Otak depan berkembang menjadi mata (saraf kranial II) dan hemisfer otak. Perkembangan semua daerah korteks serebri terus berlanjut sepanjang masa kehidupan janin dan masa anak-anak. Sistem olfaktorius dan talamus juga berkembang dari otak depan. Saraf kranial III dan IV (occulomotorius dan trochlearis) terbentuk dari otak tengah. Otak belakang membentuk medula, spons, serebelum, dan saraf kranial lain.

Gelombang otak dapat dicatat melalui elektroensefalogram (EGG) pada minggu ke-8. Medula spinalis terbentuk dari ujung panjang tabung neural. Pada mudigah, korda spinalis berjalan sepanjang kolumna vertebralis, tetapi setelah itu korda spinalis tumbuh lebih lambat. Pada minggu ke-24, korda spinalis memanjang hanya sampai S1, saat lahir sampai L3 dan pada orang dewasa sampai L1. Mielinisasi korda spinalis mulai pada pertengahan gestasi dan berlanjut sepanjang tahun pertama kehidupan.

Fungsi sinaps sudah cukup berkembang pada minggu ke depalan sehingga terjadi fleksi leher dan badan. Struktur ektodermal lainnya, neural crest, berkembang menjadi sistem saraf perifer. Sel neural crest yang terlepas dari tepi lateral lipatan neural menghasilkan ganglion spinal dan ganglion sistem 
autonom, serta sejumlah sel jenis lain. Mesoderm paraksial, yang paling dekat dengan notokord dan neural tube yang sedang berkembang, berdiferensiasi untuk membentuk pasangan blok jaringan atau somit. Somit pertama muncul pada hari ke 20. Terdapat sekitar 30 pasangan somit pada hari ke-30 yang meningkat menjadi total 44 pasangan. Somit berdiferensiasi menjadi sklerotom, miotom, dan dermatom yang masing-masing menghasilkan tulang rangka sumbu, otot rangka dan dermis kulit.

\section{Perkembangan Saraf janin Intrauterus}

\section{Trimester I (0-12 minggu)}

1. Pada minggu ke-8, serabut-serabut saraf tersebar ke seluruh tubuh.

2. Pada usia 10 minggu, rangsangan lokal dapat memicu gerakan berkedip, gerakan membuka mulut, penutupan jati tangan yang tidak sempurna, dan fleksi plantar jari kaki.

3. Minggu ke-11 atau ke-12, janin membuat gerakan napas, menggerakkan seluruh anggota geraknya dan mengubah posisi di dalam rahim.

4. Janin dapat mengisap ibu jarinya dan berenang dalam kolam cairan amnion, bersalto, dan mungkin membuat simpul pada korda umbilikalis.

5. Janin berespons terhadap kebisingan, sinar yang kuat, stimulasi yang mengganggu pada kulit, dan penurunan suhu dengan mengubah respons otonom, misalnya kecepatan denyut jantung dan dengan bergerak.

\section{Trimester II (12-28 minggu)}

1. Gerakan janin dapat dirasakan sejak usia gestasi 14 minggu : "latihan fisik" diperkirakan membantu pertumbuhan otot dan ekstremitas. 
2. Pada minggu ke-16, sistem saraf janin mulai berfungsi. Stimulasi dari otak sudah direspon oleh otot-otot sehingga janin bisa mengoordinasikan gerakannya.

3. Janin makin aktif bergerak. Dia menendang-nendang bahkan melakukan aksi berputar dalam rahim ibu. Apabila gerakan cukup kuat untuk dirasakan ibu sebagai gerakan bayi, maka terjadilah quickening. Untuk multipara, perasaan ini biasanya dialami setelah minggu ke-16 gestasi. Pada multipara, quickening dapat dirasakan lebih awal. Pada waktu itu, ibu menjadi sadar akan siklus tidur dan bangun janin.

\section{Trimester III (28-36 minggu)}

1. Perkembangan pesat dalam tubuh janin pada awal bulan ke-7 terjadi pada sistem saraf pusatnya, terutama pada otaknya. Bagian otak yang mengalami perkembangan paling pesat adalah otak yang mengelola proses penyampaian informasi kepada organ pendengaran, serta organ penglihatan. Perkembangan ini memungkinkan si kecil mampu mengenali dan membedakan antara suara ibu dan anggota keluarga lainnya, meskipun suara yang didengar belum sejernih suara aslinya. Kelopak matanya juga telah dapat membuka dan menutup.

2. Bola matanya telah dapat digunakan untuk melihat. Bila si ibu berdiri di tempat yang cukup terang, si kecil dapat melihat siluet benda-benda di sekitar ibunya.

3. Memasuki bulan ke-9, proses yang terjadi bukanlah proses pembentukan tetapi lebih bersifat penyempurnaan. Selama trimester ketiga ini, integrasi fungsi saraf otot berlangsung secara pesat.

Pada aterm susunan saraf sudah siap untuk menerima dan mengolah informasi. Fungsi korteks serebrum pada manusia relatif 
imatur dibandingkan dengan yang ditemukan pada spesies mamalia lainnya. Mielinisasi sempurna pada jalur motorik yang panjang terjadi setelah lahir sehingga gerakan halus jari tangan, belum tampak sampai beberapa bulan setelah lahir.

\section{Perkembangan Saraf Janin Ekstra-Uterus}

Setelah lahir, susunan saraf mengalami perkembangan pesat sebagai respons terhadap peningkatan input sensorik. Refleks mungkin sedikit tertekan pada 24 jam pertama, terutama apabila terjadi penyaluran transplasenta analgesia narkotik, tetapi kemudian beberapa refleks mulai tampak. Pada kasus asfiksia berat, akan ditemukan nilai APGAR yang rendah atau kerusakan saraf, refleks tertekan atau mungkin memerlukan waktu lebih lama untuk muncul.

1. Refleks menggenggam atau refleks Moro digunakan untuk menilai kemampuan refleks bayi baru lahir.

2. Bayi juga memperlihatkan genggaman palmar yang kuat dan gerakan melangkah ritmis. Banyak refleks yang terdapat pada neonatus akan menghilang kecuali apabila terjadi proses patologis, yaitu refleks tersebut muncul pada masa dewasa.

3. Bayi memperlihatkan kesadaran umum akan keadaan di sekitarnya dan bereaksi terhadap suara dan cahaya.

4. Bayi lahir dengan jalur sensorik yang aktif.

5. Penelitian membuktikan bahwa neonatus dapat mengenali bau ASI. Mereka dapat membedakan rasa dan tampaknya lebih menyukai rasa manis.

6. Walaupun bayi sudah dapat melihat pada saat lahir, terjadi perkembangan pesat kemampuan visual dalam 6 bulan pertama. 
7. Neonatus memperlihatkan ketajaman penglihatan yang terbatas, tetapi tampaknya berfokus pada jarak $20 \mathrm{~cm}$. Sejak lahir, bayi dapat membedakan antara kontras dan kontur, serta dapat mengikuti gerakan.

8. Neonatus mampu mendengar dan membedakan suara, terutama yang berfrekuensi rendah sampai sedang. Penelitian membuktikan bahwa neonatus mengenal suara ibu mereka dan lebih menyukai intonasi ritmis mengalun seperti menyanyi. Neonatus terbuai oleh suara ritmis bernapas, denyut jantung, dan peristaltik usus, yang mereka dengar, misalnya saat digendong.

9. Bayi tampak terfokus pada rangsangan visual dan tampaknya mengolah informasi sensorik.

10. Pada keadaan terjaga aktif. Kecepatan pernapasan meningkat dan ireguler.

11.Terjadi perubahan warna kulit, banyak aktivitas, dan bayi memperlihatkan peningkatan kepekaan terhadap rangsangan. Menangis adalah cara berkomunikasi yang biasanya merupakan respons terhadap rangsangan yang tidak menyenangkan. Biasanya neonatus menutup mata mereka, menyeringai, dan mengeluarkan suara. Namun, bayi prematur mungkin tidak mampu membuat keributan.

Dahulu pernah dianggap bahwa tingkat mielinisasi yang belum sempurna dan tidak adanya pengalaman menyebabkan neonatus tidak dapat merasakan nyeri. Persyaratan anatomis dan fungsional untuk merasakan nyeri sudah berkembang sejak awal dan neonatus memperlihatkan respons fisiologis serupa dengan orang dewasa, yaitu pengeluaran katekolamin dan kortisol meningkat, kecepatan denyut jantung dan pernapasan berubah, laju metabolisme dan konsumsi oksigen meningkat, dan kadar glukosa darah meningkat. Kecepatan penyaluran rangsangan mungkin 
lebih lambat, tetapi jarak antara reseptor nyeri dan otak yang lebih pendek mengompensasi hal tersebut. Penilaian nyeri mungkin sulit dilakukan karena nyeri dapat diekspresikan secara berbeda; ekspresi wajah dapat digunakan, tetapi sebagian bayi cenderung menarik diri dan meningkatkan kepasifan dan pola tidur sebagai respons terhadap nyeri.

\section{Imunologi}

Neonatus mewarisi banyak kekebalan dari ibunya karena banyak antibodi berdifusi dari darah ibu melalui plasenta masuk fetus. Akan tetapi, neonatus sendiri tidak membentuk antibodi dalam arti yang bermakna. Menjelang akhir bulan pertama, gamma globulin bayi yang mengandung antibodi, turun sampai kurang dari separuh kadar semula disertai penurunan kekebalan sebanding. Kemudian proses imunisasi bayi mulai membentuk antibodi, dan konsentrasi gamma globulin pada hakekatnya kembali ke normal menjelang usia 6 sampai 20 tahun.

Sistem imunitas bayi baru lahir belum matang, sehingga menyebabkan neonatus rentan terhadap berbagai infeksi dan alergi. Sistem imunitas yang matang akan memberikan kekebalan alami maupun yang didapat.

Kekebalan alami terdiri atas struktur pertahanan tubuh yang mencegah atau meminimalkan infeksi, seperti berikut ini :

1. Perlindungan oleh kulit membran mukosa.

2. Fungsi saringan saluran napas.

3. Pembentukan koloni mikroba oleh kulit dan usus.

4. Perlindungan kimia oleh lingkungan asam lambung. 


\section{BAB 8}

\section{TRANSISI NEONATAL DARI INTRA KE EKSTRA UTERUS}

\subsection{TRANSISI PADA SISTEM RESPIRASI}

Organ yang bertanggung jawab untuk oksigenasi sebelum bayi lahir adalah placenta. Selama masa dalam kandungan, janin mengalami banyak perkembangan yang menyediakan infrastruktur untuk mulainya proses pernapasan. Pada masa kehamilan di trimester II atau III janin sudah mengembangkan otot-otot yang diperlukan unt bernafas, alveoli juga berkembang dan sudah mampu menghasilkan surfaktan, fosfolipid yang mengurangi tegangan permukaan pada tempat pertemuan antar udara-alveoli. Ruang interstisial antar alveoli sangat tipis sehingga memungkinkan kontak maksimum antara kapiler dan alveoli untuk pertukaran udara.

Pada saat bayi lahir, dinding alveoli disatukan oleh tegangan permukaan cairan kental yang melapisinya. Diperlukan lebih dari 25 mmhg tekanan negatif untuk melawan pengaruh tegangan 
permukaan tersebut dan untuk membuka alveoli pertama kalinya. Tetapi begitu membuka alveoli, pernapasan selanjutnya dapat dipengaruhi pergerakan pernafasan yang relatif lemah. Untungnya, pernafasan bayi baru lahir yang pertama kali sangat kuat, biasanya mampu menimbulkan tekanan negatif sebesar 50 $\mathrm{mmHg}$ dalam ruang intrapleura.

Pada bayi baru lahir, kekuatan otot-otot pernapasan dan kemampuan diafragma untuk bergerak secara langsung akan mempengaruhi keadekuatan setiap inspirasi dan ekspirasi. Bayi baru lahir yang sehat mengatur sendiri usaha bernafas sehingga mencapai keseimbangan yang tepat antara oksigen, karbon dioksida, dan kapasitas residu fungsional. Frekuensi napas pada bayi baru lahir normalnya adalah 40 kali per menit, dengan atau tanpa cuping hidung. Suara dı 184 atau retraksi dinding dada jelas merupakan respon abnormal pada 2 jam setelah kelahiran.

\subsection{TRANSISI PADA SISTEM KARDIOVASKULER}

Struktur anatomi pada sirkulasi fetal bersifat khas. Paru tidak berfungsi selama kehidupan fetal dan hatinya berfungsi sebagian, maka tidak perlu bagi jantung janin untuk memompa banyak darah baik melalui paru atau hati. Sebaliknya, jantung janin harus memompa darah dalam jumlah besar melalui plasenta. Oleh karena itu, susunan anatomi sistem sirkulasi fetal bekerja sangat berbeda dengan sistem sirkulasi orang dewasa. 


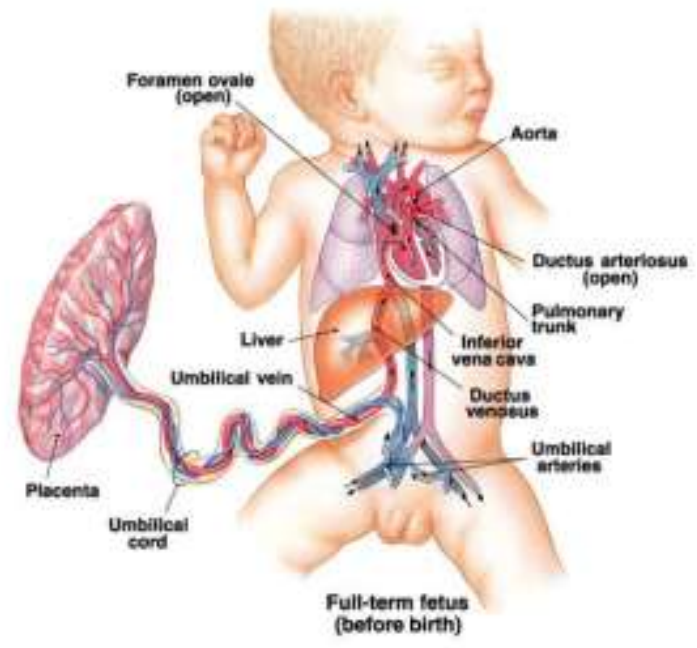

Darah yang kembali dari placenta melalui ductus venosus sebagian besar akan masuk ke atrium kanan, dari vena kava inferior langsung berjalan lurus melalui permukaan posterior atrium kanan dan kemudian melalui foramen ovale langsung masuk ke dalam atrium kiri. Jadi darah mengalami oksigenasi dengan baik dari plasenta masuk ke sisi kiri jantung bukan sisi kanan. Jantung memompa ventrikel kiri terutama ke dalam pembuluh kepala dan anggota badan atas.

Darah yang masuk atrium kanan dari vena kava superior langsung berjalan terus melalui katup trikuspidalis masuk kedalam ventrikel kiri. Darah ini terutama darah teroksigenasi dari daerah kepala dalam arteri pulmonalis kemudian melalui duktus arteriosus masuk ke dalam aorta desendens dan melalui arteri umbilikalis masuk plasenta. Jadi darah deksigenasi mengalami oksigenasi. 


\section{Perubahan primer resistensi vaskuler paru dan resistensi vaskuler sistemik waktu lahir meliputi :}

1. Hilangnya aliran darah dalam jumlah besar melalui plasenta yang kira-kira dua kali lipat resistensi vaskuler sistemik waktu lahir

2. Resistensi vaskuler paru sangat banyak menurun akibat pengembangan paru

3. Penutupan foramen ovale

\subsection{TRANSISI PADA TERMOGULASI}

Saat di dalam rahim ibu, janin tidak perlu mengatur suhu tubuh, karena suhu di dalam uterus hanya berfluktuasi sedikit. Suhu janin biasanya lebih tinggi $0.60 \mathrm{C}$ dibandingkan suhu ibu. Sebaiknya, setelah dilahirkan bayi akan kehilangan sebagian panas tubuhnya. Panas tubuh yang hilang dipengaruhi oleh beberapa faktor berikut ini :

1. Luas area permukaan tubuh bayi yang terbuka.

2. Tingkat insulasi lemak subkutan.

3. Derajat fleksi otot.

Bayi yang lahir cukup bulan dengan badan lahir yang normal dan memiliki fleksi otot yang baik memiliki perlindungan yang alami terbaik terhadap kehilangan panas.

Kehilangan panas tubuh pada bayi dapat terjadi melalui empat cara, yaitu konveksi, konduksi, evaporasi dan radiasi. Di sisi lain bayi baru lahir dapat menghasilkan panas tubuh dengan cara :

1. Menggigil; cara ini kurang efisien, karena muncul hanya pada kondisi stress dingin yang berat

2. Aktivitas otot yang volunter; manfaat sangat terbatas

3. Termogenesis tanpa menggigil; yaitu peningkatan kecepatan metabolisme atau penggunaan lemak coklat (brown fat) untuk memproduksi lemak. Brown fat dimobilisasi untuk menghasilkan panas. 


\subsection{TRANSISI PADA KEMAMPUAN MEMPEROLEH SUMBER GLUKOSA.}

Saat bayi lahir dan tali pusatnya diklem, bayi harus menemukan cara untuk mempertahankan keseimbangan glukosa yang esensial bagi fungsi otaknya. Pada setiap bayi baru lahir, kadar glukosa darah akan turun selama periode waktu yang singkat (1-2 jam setelah kelahiran).

Sistem pada bayi baru lahir yang sehat akan belajar untuk mengoreksi secara mandiri penurunan kadar glukosa darah tersebut melalui tiga cara yaitu :

1. Melalui penggunaan ASI.

2. Melalui cadangan glikogen.

3. Melalui pembuatan glukosa dari sumber - sumber lain, khususnya lipid.

Bayi baru lahir yang sehat menghasilkan glukosa sebanyak 4-8 $\mathrm{mg} / \mathrm{KgBB} /$ menit sebagai respon terhadap kebutuhannya. Kemampuan untuk mengoreksi secara mandiri kadar glukosa darah adalah bagian penting bagi kelangsungan hidup bayi di luar rahim.

\subsection{TRANSISI PADA DARAH}

Umumnya bagi bayi baru lahir dilahiran dengan nilai hemoglobin $\mathrm{Hb}$ yang tinggi. Hemoglobin $\mathrm{F}$ adalah $\mathrm{Hb}$ yang dominan pada periode janin, namun akan berangsur angsur lenyap pada satu bulan pertama kehidupan, terutama selama beberapa hari pertama. Nilai $\mathrm{Hb}$ akan meningkat sedangkan volume plasma akan menurun, akibatnya hematokrit normal hanya terjadi pada $51-56 \%$ bayi baru lahir. 
Saat dilahirkan, nilai $\mathrm{Hb}$ bayi meningkat dari 3\% enjadi $6 \%$, dan pada minggu ke-7 sampai ke-9 setelah lahir nilai $\mathrm{Hb}$ akan turun perlahan. Nilai Hb untuk bayi berusia 2 bulan rata-rata $12 \mathrm{~g} / \mathrm{dl}$.

\section{Faktor - faktor yang mempengaruhi nilai hemoglobin pada bayi baru lahir adalah :}

1. Waktu pengekleman tali pusat. Penundaan pengekleman tali pusat dapat meningkatkan volume darah bayi baru lahir sebanyak 25-40\%. Keuntungan penundaan pengekleman :

a. Volume yang besar meningkatkan perfusi kapiler baru.

b. Berlanjutnya bolus darah teroksigenasi selama nafas pertama yang tidak teratur.

2. Pencapaian oksigenasi adekuat yang lebih cepat membuat penutupan struktur janin.

3. Posisi bayi baru lahir segera setelah lahir.

Sel darah merah bayi baru lahir memiliki umur yang singkat yaitu 80 hari, sedangkan sl darah merah orang dewasa 120 hari. Pergantian sel yang cepat ini menghasilkan lebih banyak sampah metabolik akibat penghancuran sel termasuk bilirubin yang harus di metabolisme. Muatan bilirubin yang berlebihan menyebabkan ikterus fisiologis yang terihat pada bayi baru lahir. Oleh karena itu, terdapat hitung retikulosit yang tinggi pada bayi baru lahir yang mencerminkan pembentukan sel darah merah baru dalam jumlah besar.

Sel darah putih rata - rata pada bayi baru lahir memiliki rentang dari 10.000 hingga $30.000 / \mathrm{mm}^{3}$. peningkatan lebih lanjut dapat terjadi pada bayi baru lahir yang normal selama 24 jam pertama kehidupan. Saat bayi menangis lama juga dapat menyebabkan hitung sel darah putih mengandung granulosit dalam jumlah yang besar. 


\subsection{TRANSISI PADA SISTEM GASTROINTERSTINAL}

Sebelum lahir, janin cukup bulan mempraktikkan perilaku mengisap dan menelan. Pada saat lahirm refleks muntah dan batuk yang matur telah lenyap. Kemampuan bayi baru lahir cukup bulan untuk menelan dan mencerna sumber makanan dari luar cukup terbatas. Sebagian besar keterbatasan tersebut membutuhkan berbagai enzim dan hormon pencernaan yang terdapat di saluran cerna (mulai dari mulut sampai dengan usus).

Kemampuan absorpsi karbohidrat pada bayi baru lahir kurang efisien, namun absorpsi monosakarida (glukosa) telah efisien. Regurgutasi bayi pada bayi baru lahir disebabkan oleh sfingter jantung, sambungan esofagus bawah dan lambung yang tidak sempurna. Kapasitas lambung pada bayi baru lahir cukup bulan sangat terbatas, kurang dari $30 \mathrm{cc}$. Hal ini disebabkan karena usus bayi baru lahir relatif tidak matur dan sistem otot yang menyusun organ tersebut lebih tipis dan kurang efisien dibandingkan orang dewasa sehingga gelombang peristaltiknya sukar untuk diprediksi. Lipatan dan vili dinding usus belum berkembang sempurna. Sel epitel yang melapisi usus halus bayi baru lahir tidak berganti dengan cepat sehingga meningkatkan absorpsi yang paling efektif. Awal pemberian makan oral menstimulasi lapisan usus agar matur dengan meningkatkan pergantian sel yang cepat dan produksi enzim mikrovirus. Epitel sel yang tidak matur mempengaruhi usus untuk melindungi dirinya dari zat-zat yang sangat berbahaya.

Pada awal kehidupan, bayi baru lahir menghadapi proses penutupan usus (permukaan epitel usus menjadi tidak permeabel terhadap antigen). Sebelum penutupan usus bayi akan rentan terhadap infeksi virus/bakteri dan juga terhadap stimulasi alergen melalui penyerapan molekul-molekul besar oleh usus. Kolon bayi baru lahir kurang efisien dalam menyimpan cairan daripada kolon orang dewasa sehingga bayi cenderung mengalami komplikasi kehilangan cairan misalnya gangguan diare. 


\subsection{TRANSISI PADA SISTEM IMUNITAS}

Bayi baru lahir memiliki dua imunitas yaitu imunitas alami dan imunitas yang didapat. Imunitas alami terdiri dari struktur tubuh yang mencegah atau meminimalkan infeksi. Beberapa contoh imunitas alami meliputi :

1. Perlindungan barier yang diberikan oleh kulit dan membran mukosa.

2. Kerja saluran napas yang bertindak seperti saringan.

3. Kolonisasi pada kulit dan usus oleh mikroba pelindung.

4. Perlindungan kimia yang diberikan oleh lingkungan asam pada lambung.

Bayi baru lahir dengan imunitas pasif terhadap virus dan bakteri yang pernah menyerang ibu. Janin mendapatkan imunitas ini melalui perjalanan transplasenta dari imunoglobulin (IgG), sedangkan yang alin (IgM dan IgA) tidak dapat melewati plasenta. Adanya IgM dan IgA di dalam darah tali pusat merupakan indikasi bahwa janin secara aktif berespons terhadap penyakit atau mikroba kecuali jika ibu berespons terhadap infeksi tersebut selama hidupnya.

\subsection{TRANSISI PADA SISTEM GINJAL}

Ginjal bayi baru lahir menunjukkan penurunan aliran darah ginjal dan penurunan kecepatan filtrasi glomerulus. Kondisi itu mudah menyebabkan retensi cairan dan intoksikasi air. Fungsi tubulus tidak matur sehingga dapat menyebabkan kehilangan natrium dalam jumlah yang besar dan ketidakseimbangan elektrolit lain. Bayi baru lahir tidak mampu mengonsentrasikan (memekatkan) urine secara baik yang tercermin dalam berat urine $(1,004)$ dan osmolitas urine yang rendah. Semua keterbatasan ginjal ini lebih buruk pada bayi kurang bulan. 
Bayi baru lahir mengekskresikan sedikit urine pada 48 jam pertama kehidupan, tetapi seringkali hanya 30 hingga $60 \mathrm{ml}$. Seharusnya tidak terdapat protein atau darah dalam urine bayi baru lahir. Debris sel yang banyak dalam urine dapat mengindikasikan adanya cedera atau iritasi di dalam sistem ginjal. 


\section{DAFTAR PUSTAKA}

Abdul Bari, Saifuddin. 2002. Panduan Praktis Pelayanan Kesehatan Maternal dan Neonatal. Jakarta : YBPSP.

American College of Obstetrican and Gynecologist: Shoulder

Dystocia. Practice Bulletin. No. 40/November 2002.

Campbel, N.A., Reece, J.B., Mitchell, L. G. 2004. Biologi, Edisi kelima Jilid 3. Jakarta: Erlangga.

Christina, Y. 2001. Esensial Obstetri dan Ginekologi. Jakarta: ECG.

Chumbley, Jane. 2003. Tips Soal ASI dan Menyusui. Jakarta: Erlangga.

Cunningham, F.G., et al. 2005. William Obstetrics, $22^{\text {nd }}$ ed. USA: McGrawhill.

Dean, G.S., Tyrrll-Price, J., Crawley, E., dan Isenberg, D. A. "Cytokines and Systemic Lupus Erythematosus". Ann Rheum Dis. 59: 243-251/2000.

Drife, J., Magowan, B. A. (ed). 2004. Clinical Obstetrics and Gynaecology. Philadelphia: WB Saunders.

Ferguson, J. E., Newberry. Y. G., DeAngelis. G. A. et al. "The Fetal-

Pelvic Index Has Minimal Utility in Predicting Fetal-Pelvic Disproportion". Am J Obstet Gynecol. 179;1186/1998.

Gherman, R. B., Ouzounian. J. G., Satin, A. J. et al. "A Comparisson

of Shoulder Dystocia-Associated Transient and Permanent

Brachial Plexus Palsies". Obstet Gynecol. 95:43/2003.

Guyton, A.C. 1990. Fisiologi Manusia dan Mekanisme Penyakit.

Terjemahan dari: Human Physiology and Mechanisme of

Disease. Alih bahasa: Petrus Andrianto. Edisi 3. Jakarta: EGC. Jennet, R. J., Tarby, T. J. "Disuse Osteoporosis as Evidence of

Brachial Plexus Plasy due to Intrauterine Fetal Maladaption". Am J Obstet Gynecol. 185:1216/2001.

Kovacs, B., Lafferty, T. L., Brent, L. H., DeHoratius, R. J. "Transverse Myelopathy in Systemic Lupus Erythematosus: an Analysis of 
14 Cases and Review of The Literature". Ann Rheum Dis. 59:120-124/2000.

Langman, J. \& Gunawan. 1977. Embriologi Kedokteran. Jakarta:

EGC.

Lin, M. G. "Umbilical Cord Prolapse". Obstet Gynecol Surv. 4/2006:61 (4): 269-277.

Nelwan, R. H. H. 2003. Patofisiologi dan Deteksi Dini Sepsis. Dalam:

Pertemuan IImiah Tahunan IImu Penyakit Dalam. 2003. Jakarta.

Pratiwi, D.A, et al. 2006. Biologi SMA Jilid 2. Jakarta: Erlangga.

Prawirohardjo, S. 2002. Perdarahan Pascapersalinan. Dalam: Buku

Acuan Nasional Pelayanan Kesehatan Maternal dan

Neonatal. Jakarta: Yayasan Bina Pustaka Sarwono Prawirohardjo (YBP-SP).

Sastrawinata, S. 2005. Obstetri Patologi. Edisi 2. Jakarta: EGC.

Saleha, Siti. 2009. Asuhan Kebidanan pada Masa Nifas. Jakarta: Salemba Medika.

Sheris, J. 2002. Kesehatan Ibu dan Bayi Baru Lahir. Edisi khusus. Seatlle: PATH.

Soetjiningsih, 1997. ASI Petunjuk untuk Tenaga Kesehatan. Jakarta: EGC.

Suryo. 1997. Genetika Manusia. Yogyakarta: Gadjah Mada University Perss.

Suryo. 1998. Genetika Strata I. Yogyakarta: Gadjah Mada University Press.

Ushiyama, O., et al. "Retinal Disease in Patient with Systemic Lupus Erythematosus". Ann Rheum Dis. 2000. 59: 705-708.

WHO. "Managing Complications in Pregnancy and Childbirth: Manual Removal of Placenta". http://www.whoint/reproductivehealth/impac/Procedures/ Manual removal P77 P79.html, 22 September 2008. 
Widodo, D., Pohan, H.T. (editor). 2004. Bunga Rampai Penyakit Infeksi. Jakarta.

Winkjosastro, H. 2005. Ilmu Kebidanan. Edisi 2. Jakarta: Yayasan Bina Pustaka Sarwono Prawirohardjo (YBP-SP).

Winkjosastro, H. 2005. Ilmu Kebidanan. Edisi 3. Cetakan 7. Jakarrta: Yayasan Bina Pustaka Sarwono Prawirohardjo (YBPSP).

Winkjosastro, H. dkk. 2002. Perdarahan Pascapartum. Dalam: IImu Bedah Kebidanan. Edisi 3. Jakarta: Yayasan Bina Pustaka Sarwono Prawirohardjo (YBP-SP). 


\section{Biodata penulis}

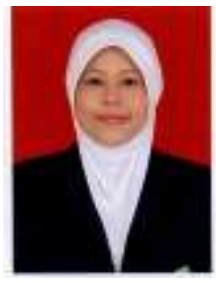

Paramitha Amelia K.,SST.,M.Keb kelahiran Purwokerto, 9 April 1986 telah meyelesaikan pendidikan formal di AKBID Siti Khodijah tahun 2007, Lulus DIV Kebidanan di STIKES Insan Unggul Surabaya dan telah menyelesaikan S2 Kebidanan di Universitas Aisiyah Yogjakarta tahun 2016. Saat ini bekerja di Universitas Muhammadiyah Sidoarjo Fakults IImu Kesehatan sebagai dosen kebidanan

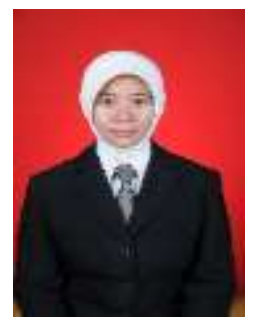

Cholifah.,SST.,M.Kes Kelahiran Mojokerto 3 November 1981 telah menyelesaikan pendidikan formal di AKBID Siti Khodijah tahun 2003, Iulus DIV Kebidanan Universitas Sebelas Maret (UNS) dan telah menyelsaikan S2 di Universitas Diponegoro pada Tahun 2014. Saat ini bekerja di Universitas Muhammadiyah Sidoarjo Fakultas IImu Kesehatan sebagai dosen kebidanan. 
Biologi adalah ilmu yang mempelajari kehidupan. Sistem reproduksi pada makhluk hidup merupakan salah satu sistem penting dan sangat mempengaruhi kelangsungan hidup manusia. Untuk mempelajari sistem reproduksi, tidak hanya sebatas anatomi saja, namun juga mempelajari fungsi dan keterkaitannya dalam kehidupan manusia. Buku ini dibuat agar pembaca memahami struktur biologi reproduksi dengan penekanan pada integrasi ilmu dan praktik kebidanan.

Buku ajar Biologi Reproduksi memuat beberapa hal mengenai hal biologi, serta sistem reproduksi manusia. Pembahasan dalam buku ini disusun berdasarkan GBPP dan kurikulum D3 Kebidanan dengan bahasa komunikatif agar pembaca dapat lebih menerima isi yang disampaikan.

Materi yang dibahas dalam buku ini mencakup :

Bab 1 Struktur dan Fungsi Sel

Bab 2 Regulasi Hormonal

Bab 3 Gametogenesis, Fertilisasi, dan Implantasi

Bab 4 Kode Genetik

Bab 5 Fisiologi Kehamilan, Persalinan, dan Nifas

Bab 6 Struktur Payudara dan Fisiologi Laktasi

Bab 7 Perkembangan dan Persiapan Kehidupan Neonatus dari Intra ke Ekstra Uterus

Bab 8 Transisi Neonatal dari Intra ke Ekstra Uterus 